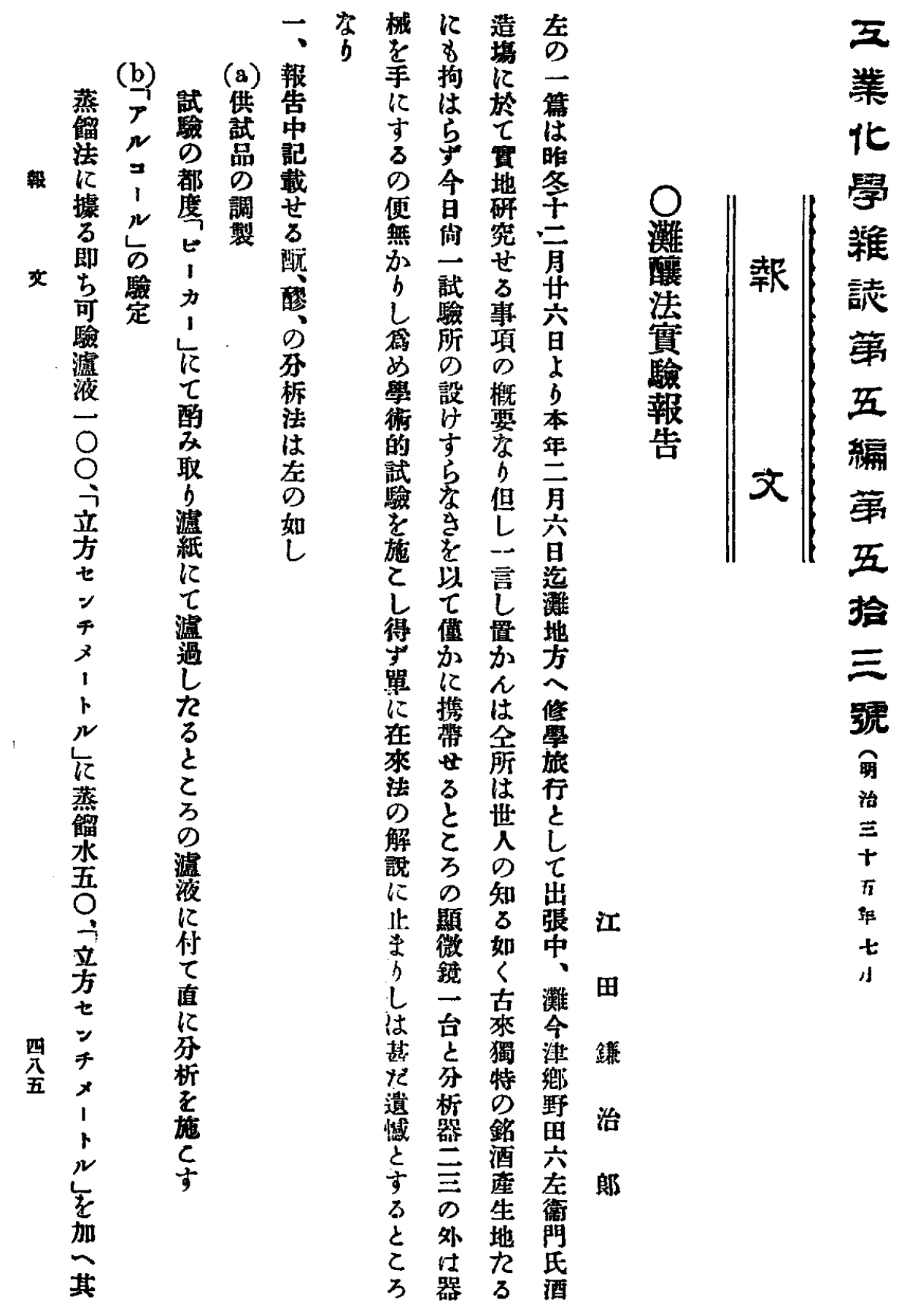




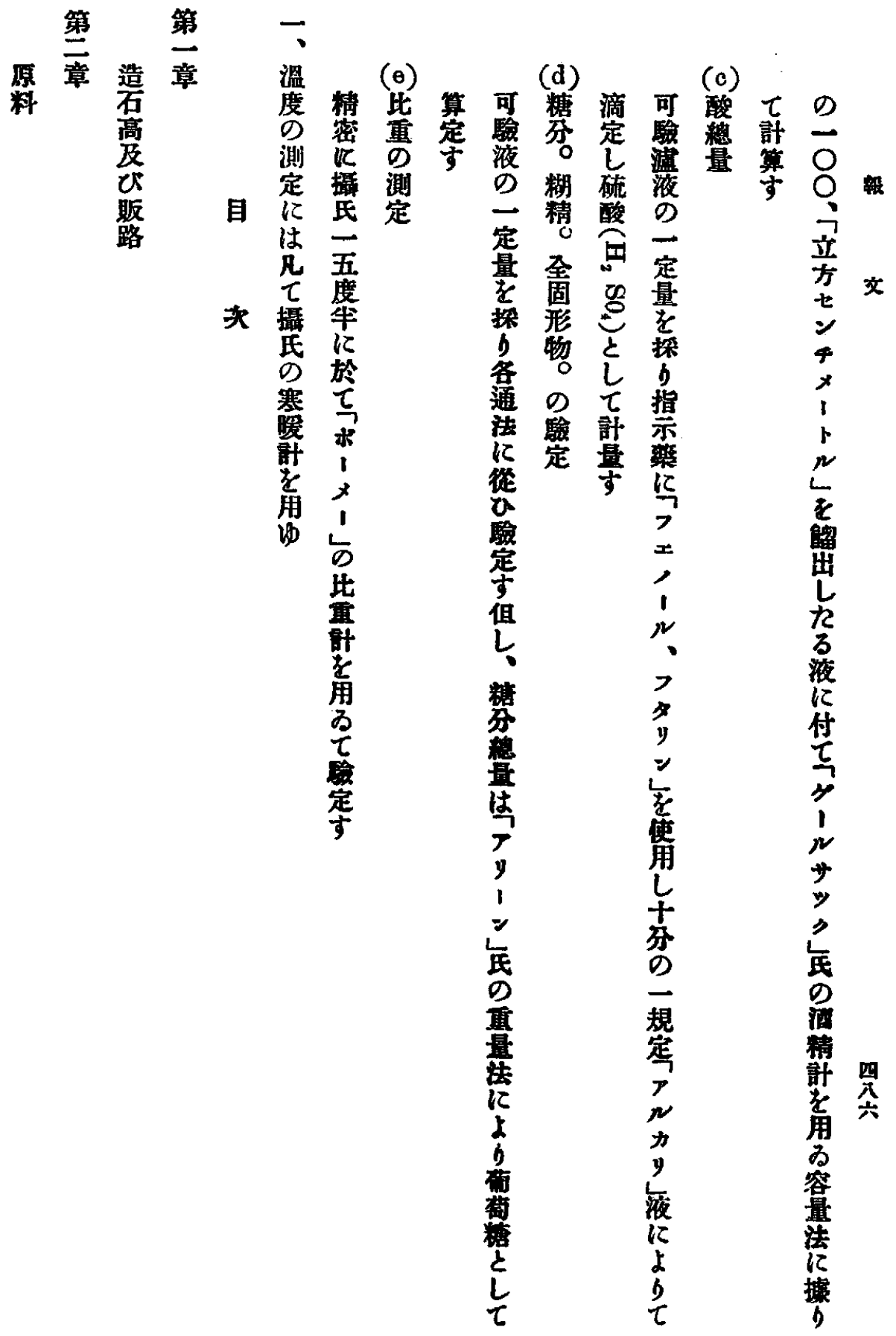




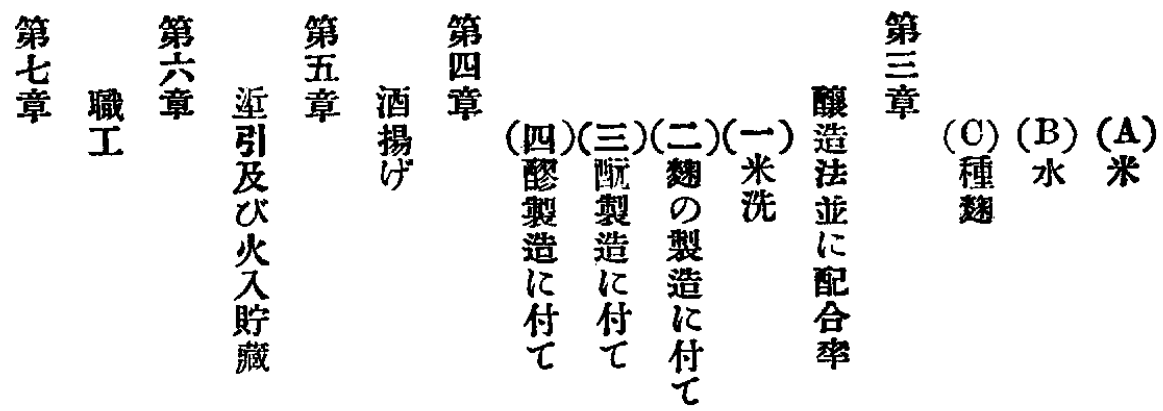




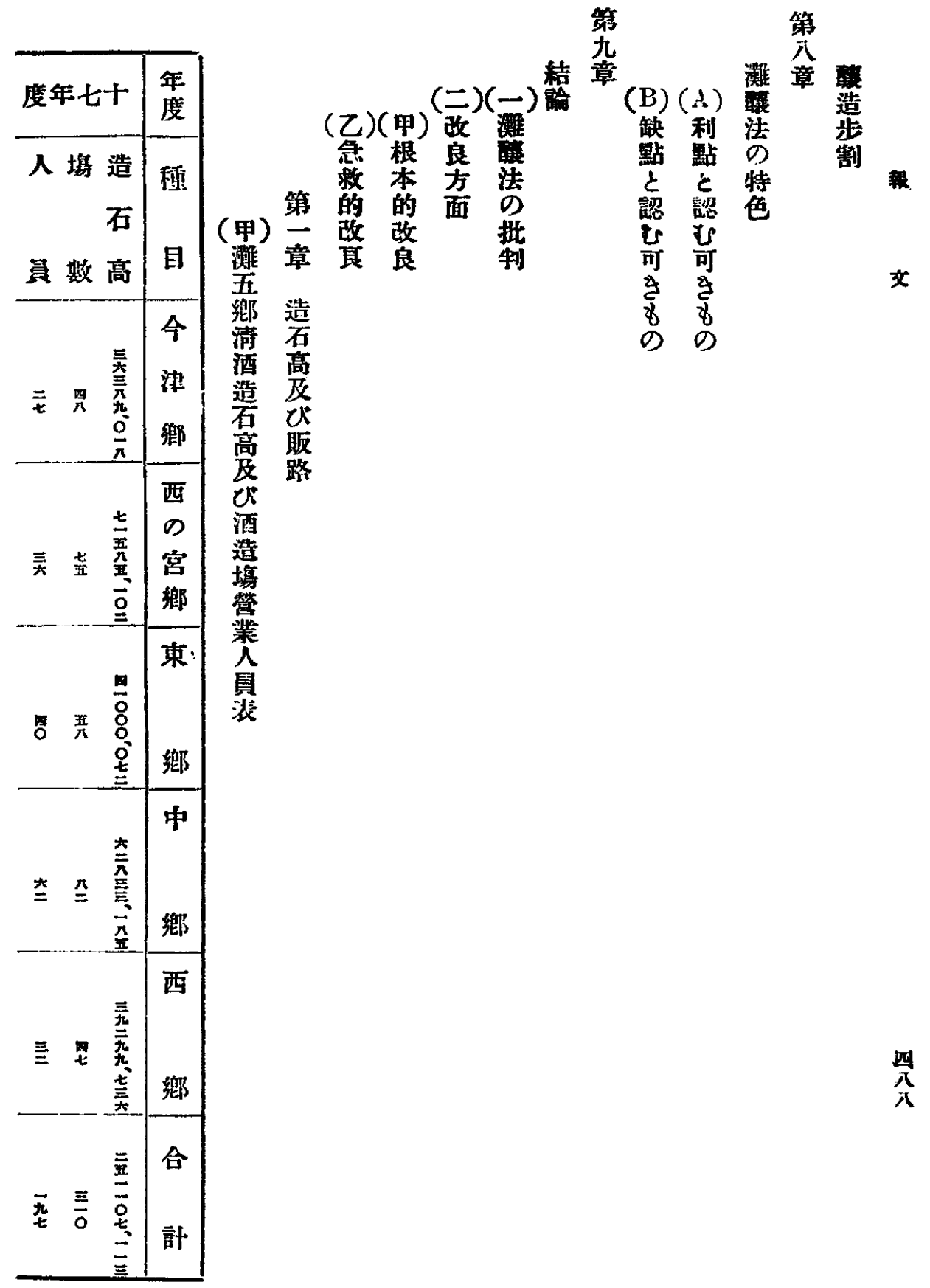




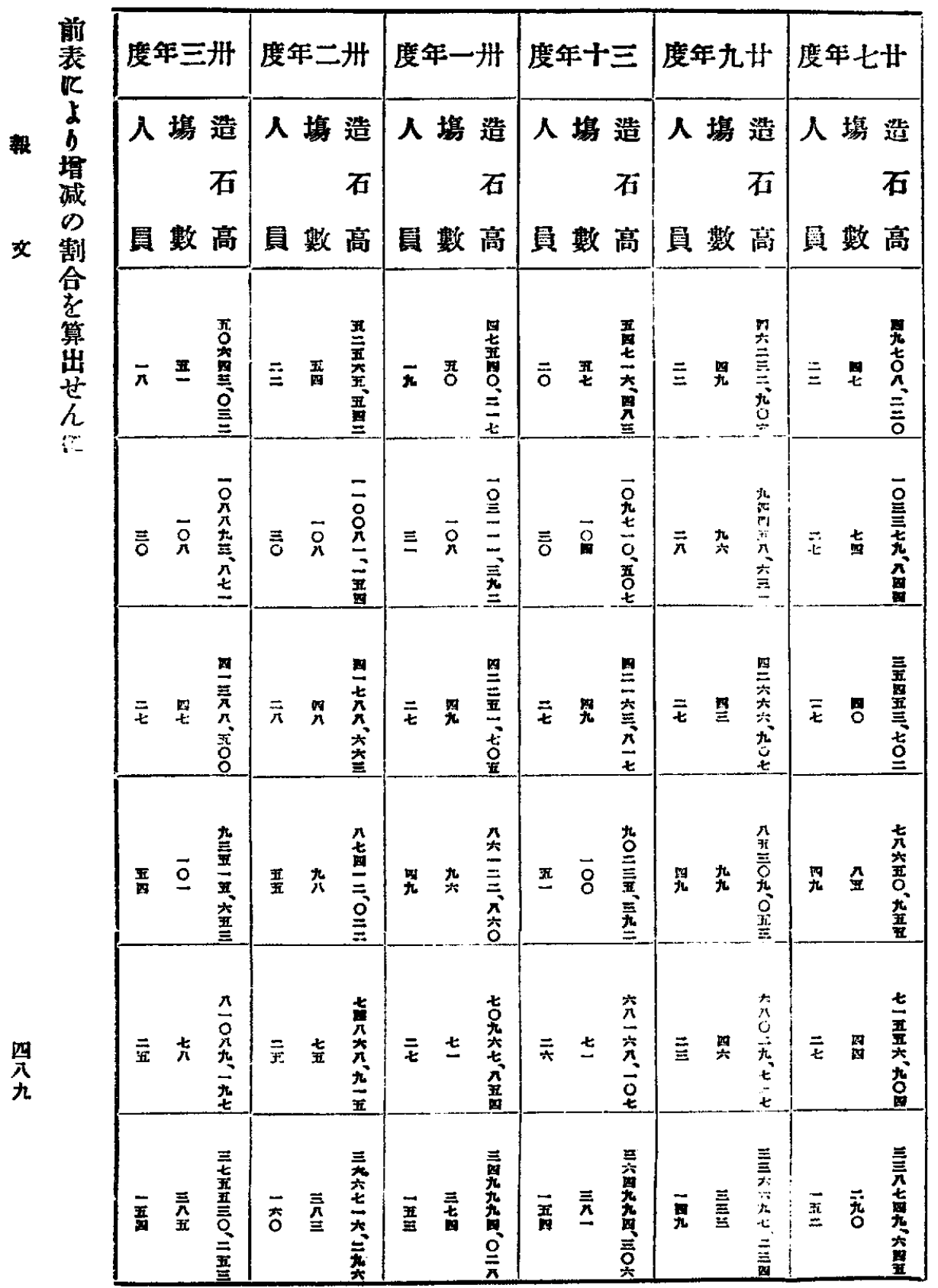


近米石、灝

來学、酒

は最四造

主良郡家

飞之のの

蒸主䨾使

汽概在角

機 し 最吉

械七良る

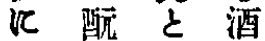

乙

珨飞粟米

拮使生沬

笅 角 米 概

所生、杖

乺る鳥 播

䓠名 井

裙の 米及

精は、ひ

畨 $三$ 攝

悉等草森

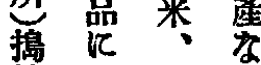

精 乙 明 b

守 $\tau$ 石 即

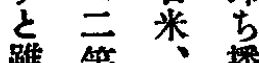

合品金

尚以谷に

⿷下米市

酒は、

屋和等

娄米は

は角名主

或に沈

万供占東

二せ 播

三 方攝州

鋸罂加

酒 東

家 b

洜㔔

沓策西

車岛美

倚郳犦

3 中

正城
各 釀

地 造

方 高

几

輸 七(乙) の

出分徵元 備

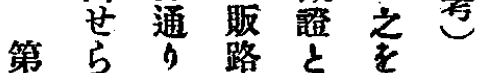

(a) 第占は路兵該

東

京

原

做

苗可任芉

は

要

n

市

丙

而

七

所

$\infty$

大

問

屋

K

依

?

索

搠

加

证

基

他

言

は

九

州

愿

紊

B
こ地

葛主方

年四

b 0 度

造 $飞$

筞

苚

人 $ᄉ$

賁

开

否

著

ᄂ \&

$<\infty$

堽は

加:

世

志

豆他

ては

潮大

狄

箱 若

的离

合 外

同

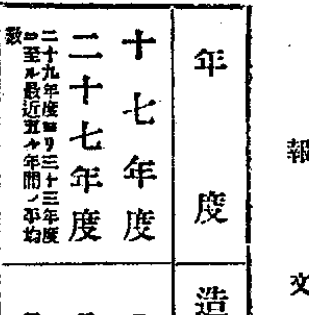

瓡

艾

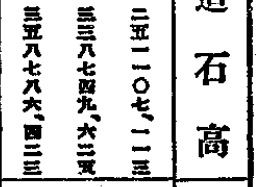

践

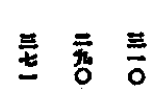

\begin{tabular}{|l|l|}
\hline & 數 \\
\hline
\end{tabular}

要要茕

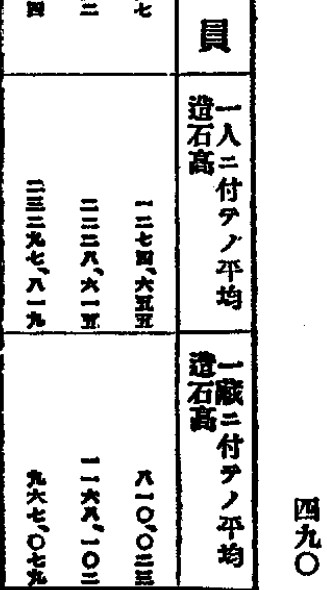

曐

噒

in 


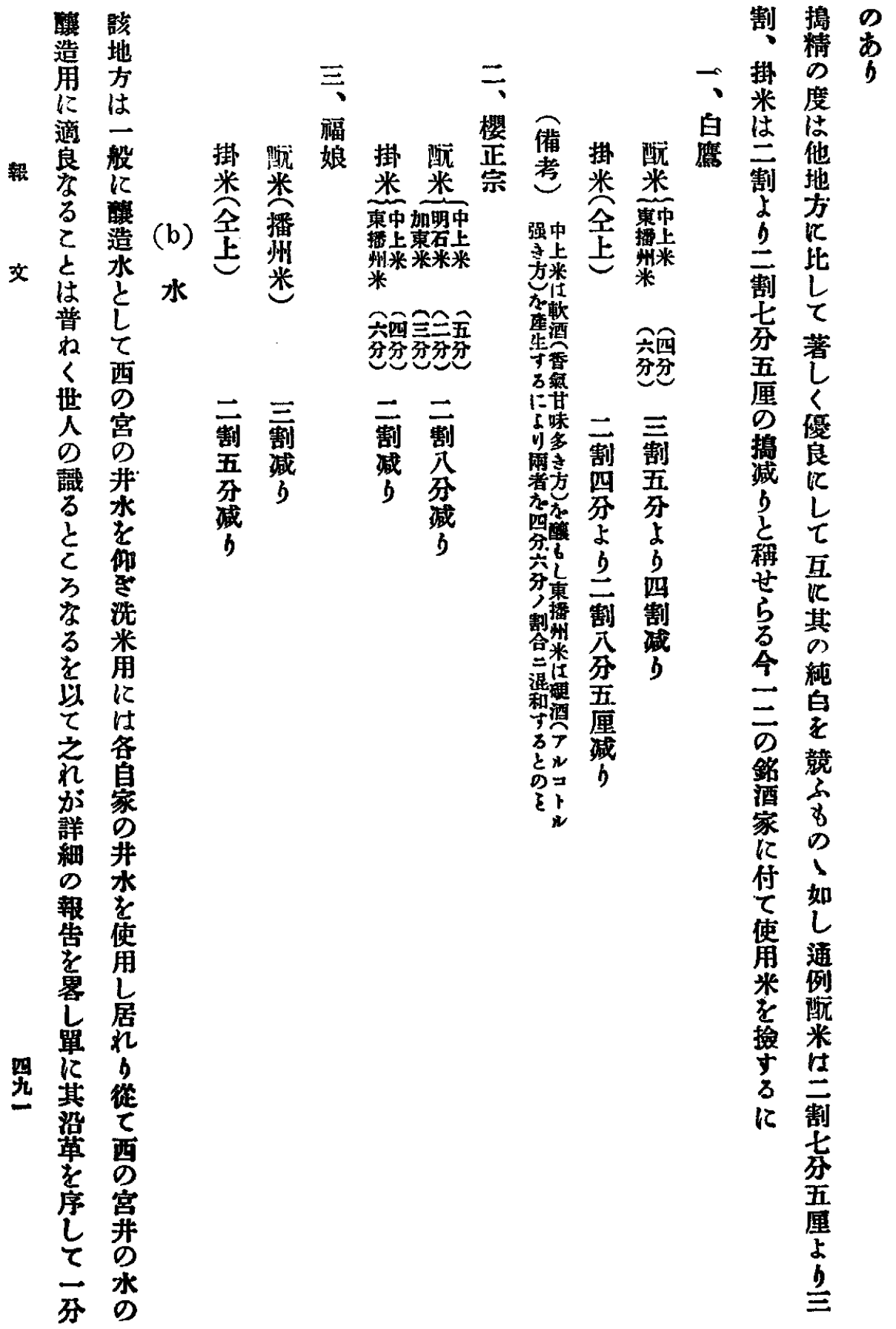




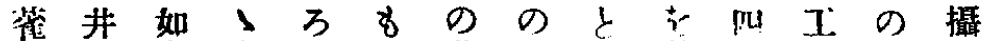

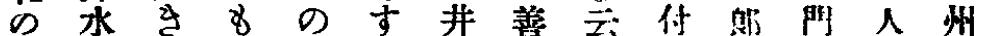

酒古の井存水良交し氐西

造以曾は水待を索此之所をの艺

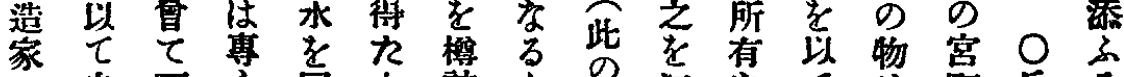

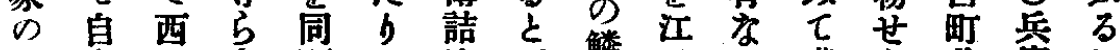

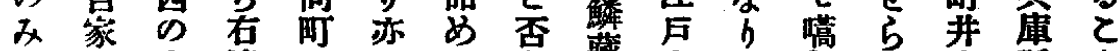

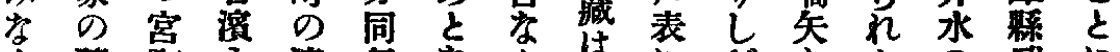

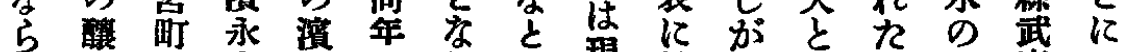

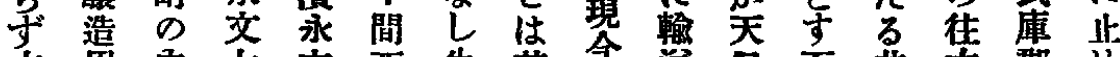

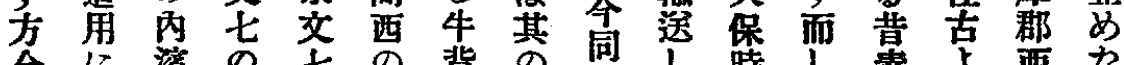

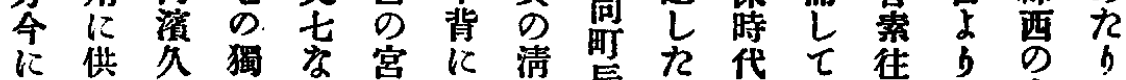

至給保占方町附酒唇 $b$ 其來酒宮

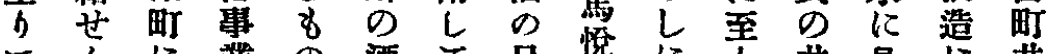

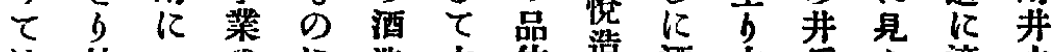

は勏一心に造之位造酒克占之適水

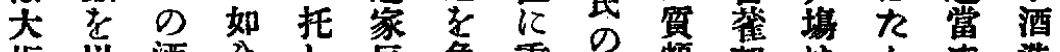

坂以酒导し辰魚重所頗部は引 的造

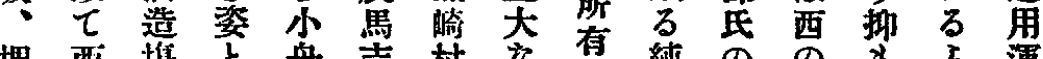

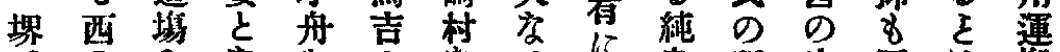

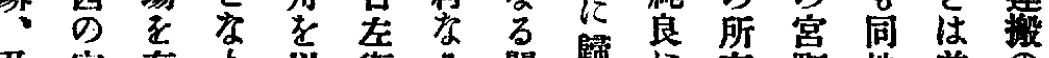

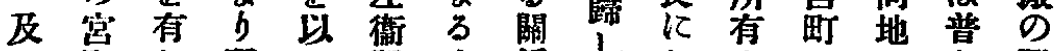

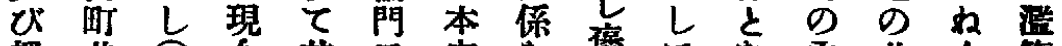

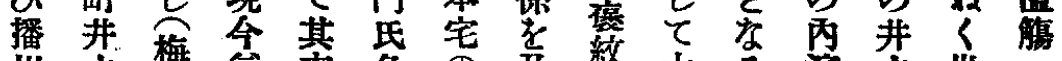

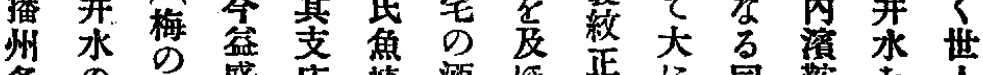

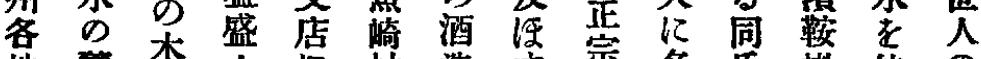

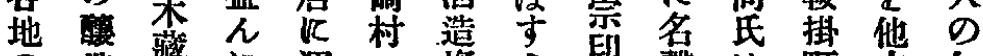

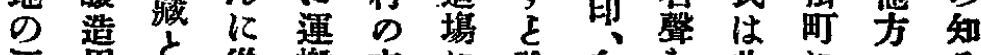
酒角会從搬支に蹁白を此に方 造適票せ

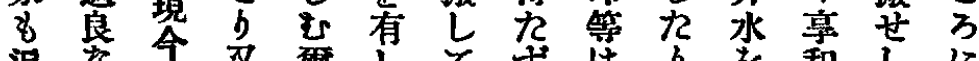

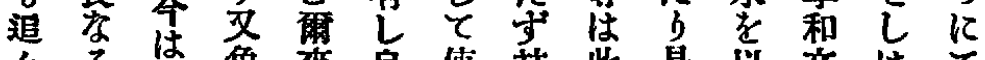
々る西鮴來自使站此是以妾はて

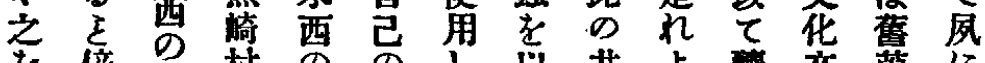
倍宮森 の

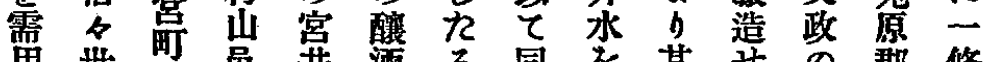
角世町芭茾酒る同基せ这郡條 し 間 圾太水白に 氏 年比吉在の鹿之はて 酒清は崎閣

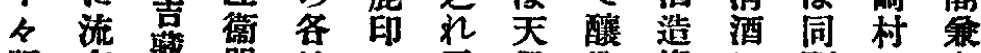

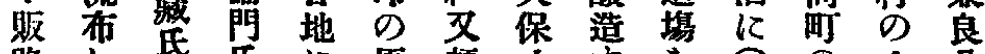
路し 氏 氏 原頗八主を鳞の人会

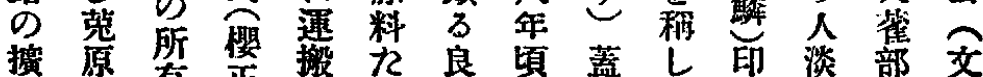

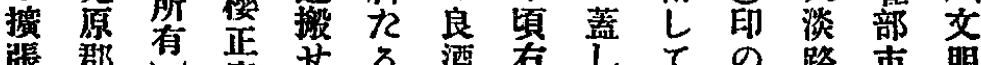

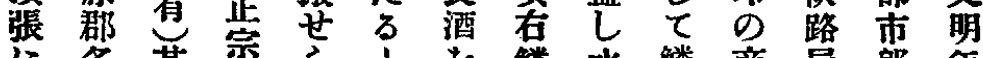
に各其誻 ら学鳞水鳞商屋郎年 從䛼の の る 


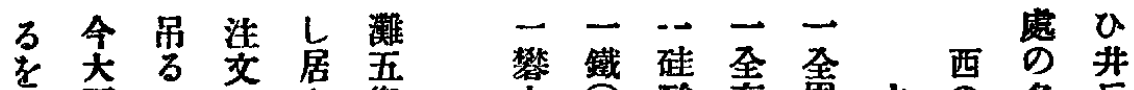

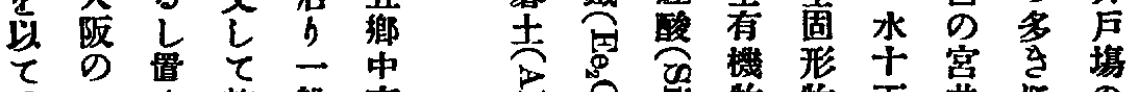

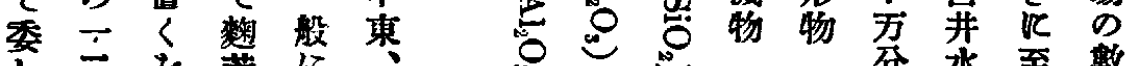

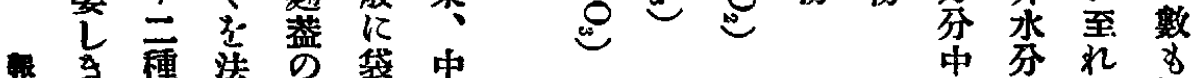

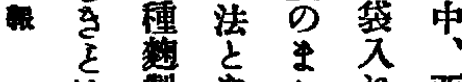
は慜 文造し取の 含析 b、潮

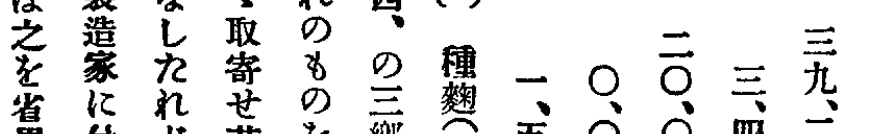

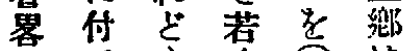

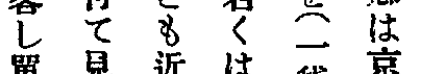

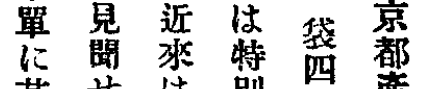

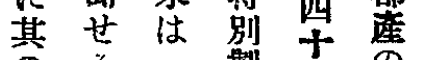

क五 0 O 四至

元 0 O 0 O

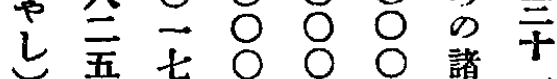

答年

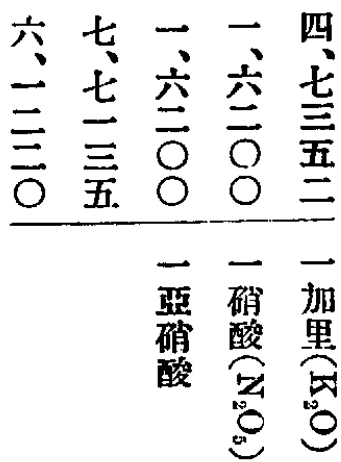

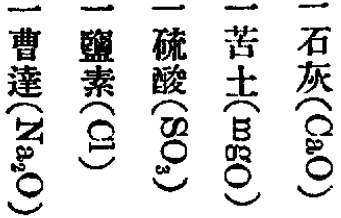

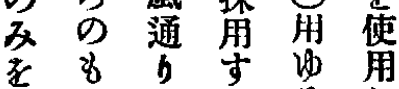

列 9 万光

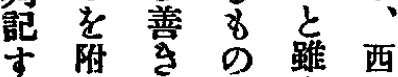

万钎場尠和

2 所尔中宮

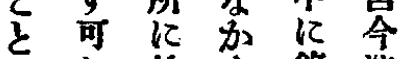

之し 放占鉝 津

L㯰酎口

艻製基家三

b 造方分度郎

法已眝㾁は

बを藏熱圭

概子方密它

要左法等

在行痤方

哭

格与㭗酒大

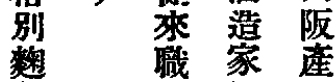

整工元更

暹集要矛

法曾

異乺港意

孛 暖特存

窒别使

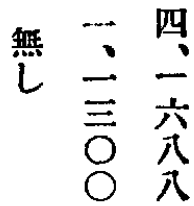

增

加

$\tau$

是

西

$\infty$

宫

数

醉

造

各

自

の

專

用

分

除

外

地

方

に

供

給

卞

る

井

椠'

殆

h

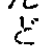


盛 取

梁

二 初

日

午 牛

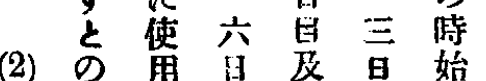

出

出程

仕畫盛

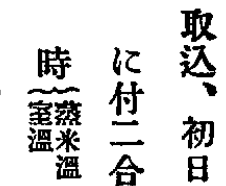

前㮍品

時時之

辛温警

重 賉满

ネ

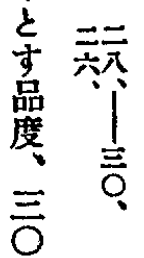

助

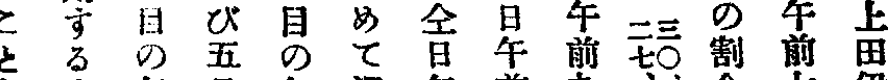

日

始" 全

全星谓鸽星

上 米午旦

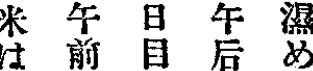

午 前

前九

韭息后名后十時!

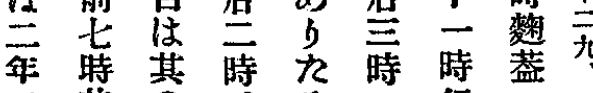

目其

行

の螖上茞

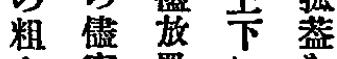

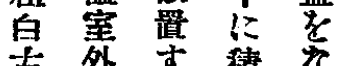

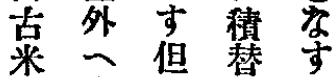

飞出的星

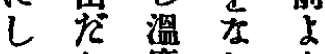

$\tau 儿$ 屋し

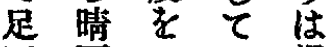

蹈天温溫

飞定度鹿

西壁衣等

十見三柡四

分計江度

間的五生位

位充六

搗分度

马 9

穴光間

3 泟

老乾保

適吕口

度点

闻

地 入

方

架察

加

賀

米

点

整

皘分

子 5

替 盛

5

禁紫

時

㿿

並

《

品

溫

共

前

r

差

素

合七伊

鞂琵

策篓

しにの

穓 木 慗

挷 可 法

ᄂ

た 䘧

光

后

粶

甍 升

辛

鹿 割

疋 合

攝老

寒混

德

䛎

こ 霓

に 依

盗之

寸 $k$

万前

年

待の

3 眝

$\tau$

栱

室 浩

に它

取蘶

已 米

此 -

探

の石 


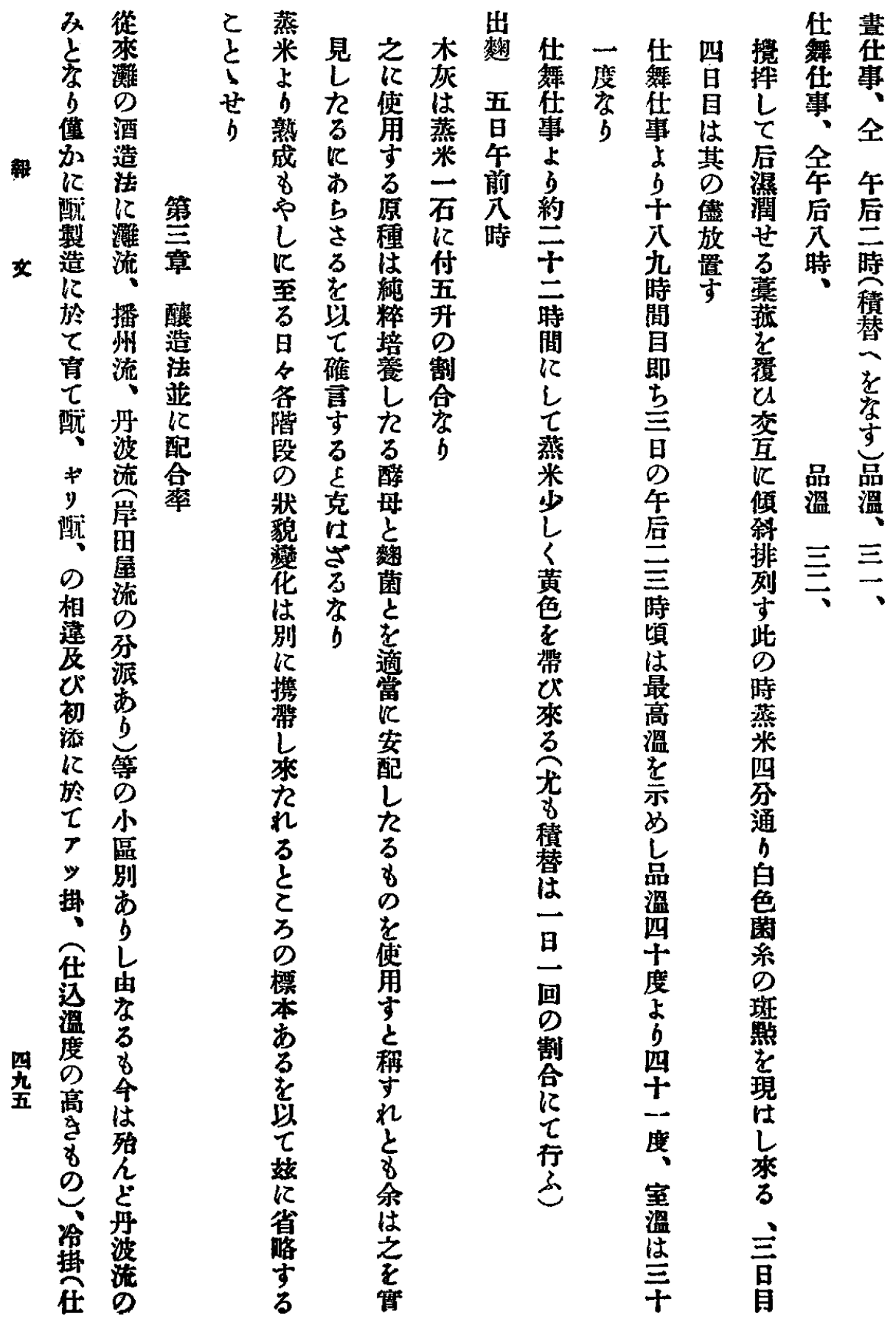




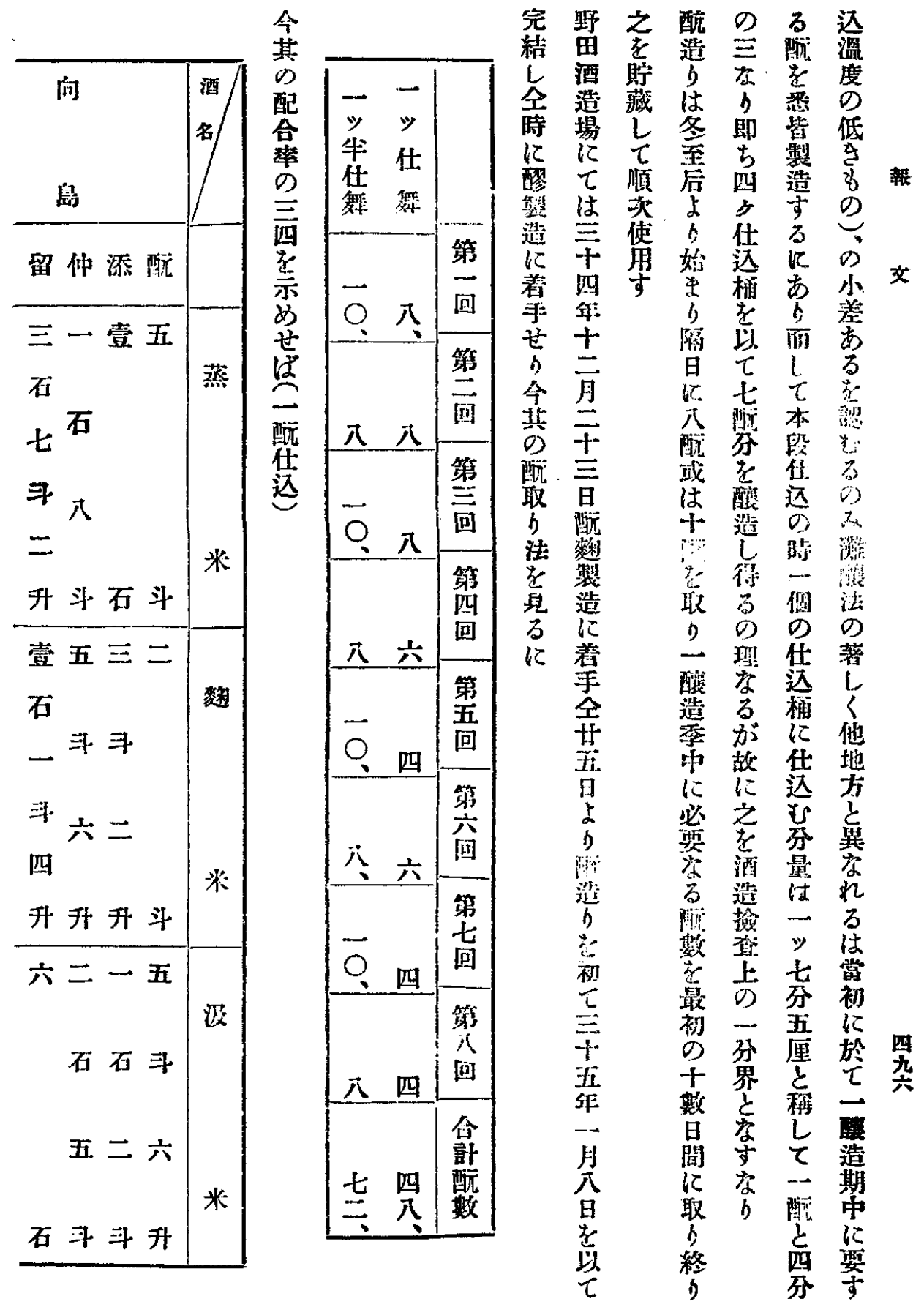




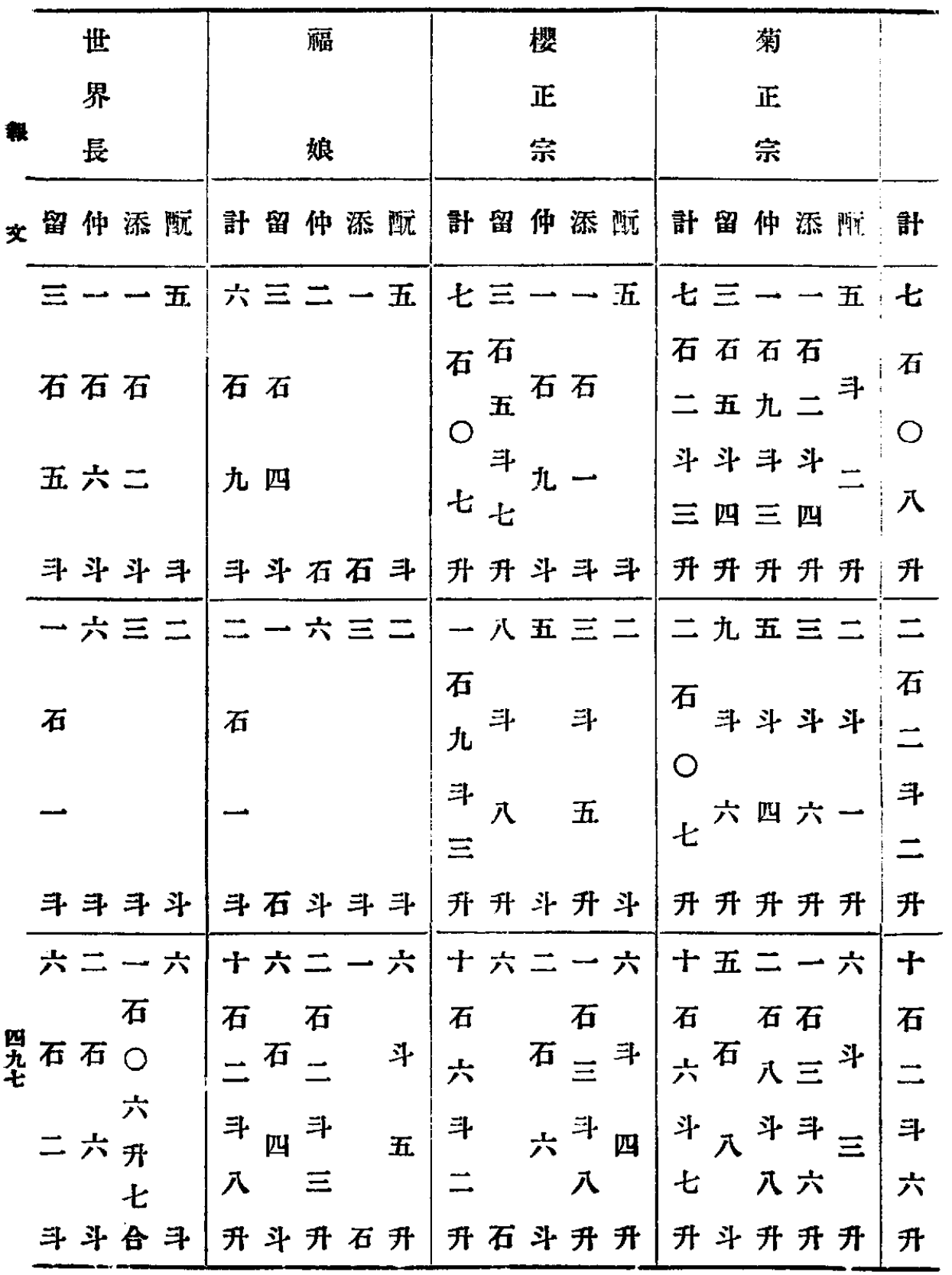




\begin{tabular}{|c|c|c|c|c|}
\hline 大 & $\begin{array}{l}\text { 惣 } \\
\text { 花 }\end{array}$ & 鷹 & 鹿 & \\
\hline 留仲添 配 & 計留仲添酛 & 計留仲添阾 & 計留仲添陮 & 計 \\
\hline$\equiv$ 三一五 & $\begin{array}{c}\text { 七三一五 } \\
\text { 石石石 }\end{array}$ & 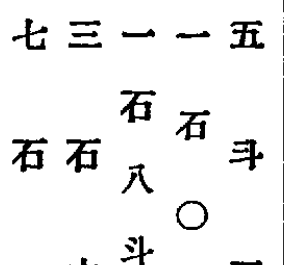 & $\begin{array}{l}\text { 七三一五 } \\
\text { 石石石石 } \\
\text { 公一丑 } \\
\text { 头入五 }\end{array}$ & 六 \\
\hline 入 & 五九一 & 一六斗 ${ }_{\text {九 }} \equiv$ & $\begin{array}{l}\text { 开开八 } \\
\text { 七三 }\end{array}$ & 八 \\
\hline 斗石石斗 & 石斗斗斗斗 & 斗斗开开升 & 升合合升升 & 丰 \\
\hline 一五三二 & 二一五三三 & 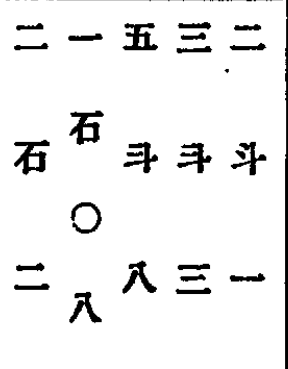 & 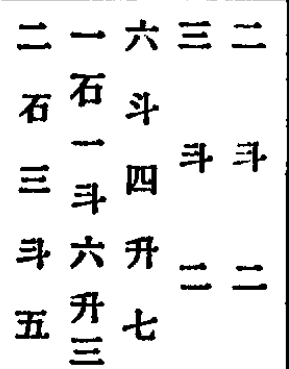 & $\begin{array}{l}= \\
\text { 石 } \\
=\end{array}$ \\
\hline 石斗斗斗 & 石石斗斗丑 & $\exists$ 升升开 & 升合合升升 & F \\
\hline 六二一太 & $\begin{array}{l}+ \text { 六二一六 } \\
\text { 石石 }\end{array}$ & $\begin{array}{l}+ \text { 六二一六 } \\
\text { 石石 }\end{array}$ & $\begin{array}{c}+ \text { 六二一六 } \\
\text { 石 } \\
\text { 淤 }\end{array}$ & $\begin{array}{l}+ \\
\text { 石 }\end{array}$ \\
\hline 石石 $\neq$ & $\begin{array}{l}\text { 四二石石 } \\
\text { 平斗 }\end{array}$ & $\begin{array}{l}\text { 六。石石 } \\
\text { 平九 }\end{array}$ & 三石 & 四照 \\
\hline 五四三 & $\begin{array}{l}\text { 六六四二 } \\
\text { 升升 } \\
\text { 七七 }\end{array}$ & $\begin{array}{l}\text { 九开六四 } \\
\text { 开五 } \\
\text { 五五 }\end{array}$ & $\begin{array}{l}\text { 九 } \text { 二开 } \\
\text { 形 开五. } \\
=\text { 三 }\end{array}$ & $\begin{array}{l}\text { 六 } \\
\text { 升 } \\
\text { 七 }\end{array}$ \\
\hline 石斗斗升 & 合合 7 斗斗 & 合合斗斗丑 & 石合 $\exists$ 合合 & 合 \\
\hline
\end{tabular}


远 $\div$ 、

甘種蒸

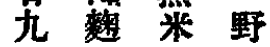

早田

帮午酒

前四一造

五十石譪

大趐多离

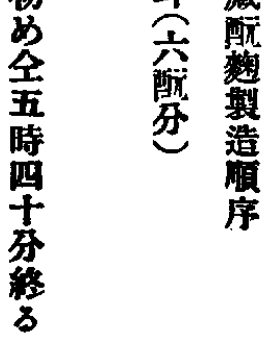

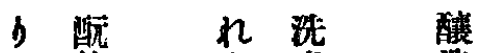

整交法

添替染

越 畫

と夜 般

は の

其

の (二) の 洗 (一) の

整名法四

造㑇多行米塤

法のしは洗に に製独

大造 七 加

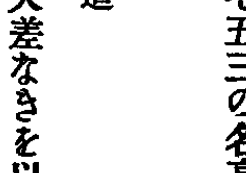

c

盟

其

D

列

告

芸

す

3

歨

总

注

温

喥

表

の

及

z

附

I

方

r

l

せ

䓊品

it

*

留

k

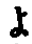

$\frac{b}{c}$

定

せ

于

通

酒

家

k

あ

号

?

生

플

梦
石石

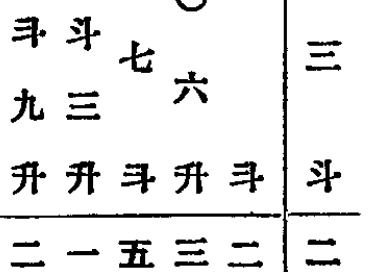

訫留伸添配計

六三一一五 t

入六石石 石

誱

皷

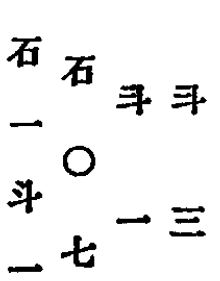

开开升开斗石

十六二一七十

石

一石斗五

$7^{\circ}$ 四 7

六四

升升斗石升 
成

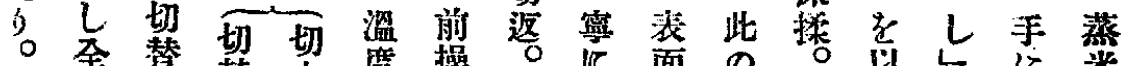

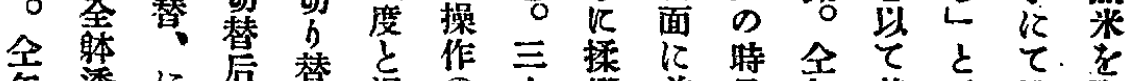

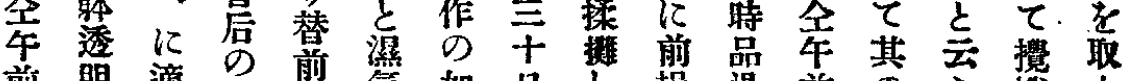

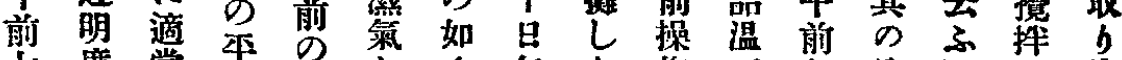

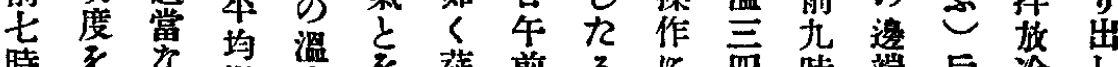

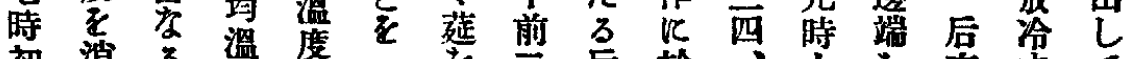

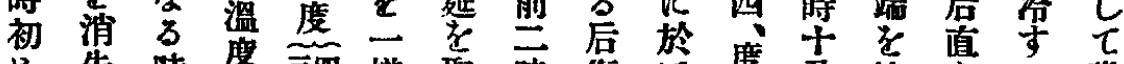

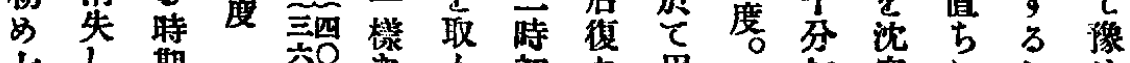

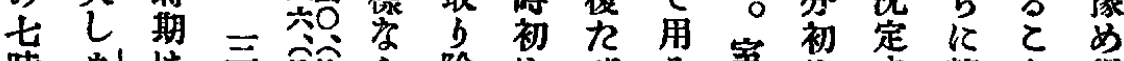

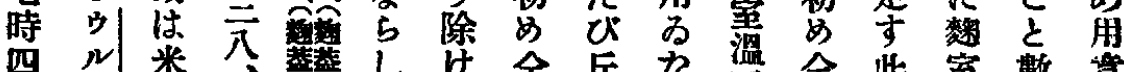

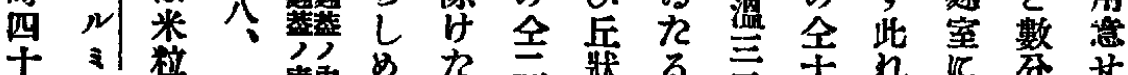

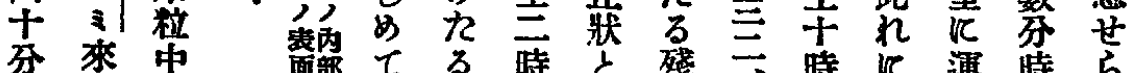

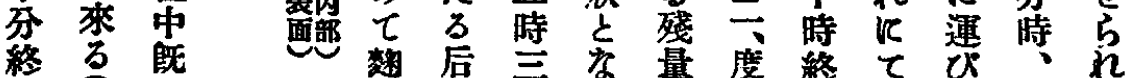

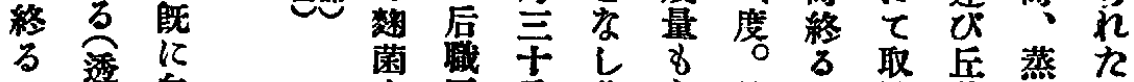

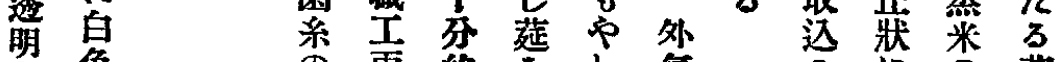

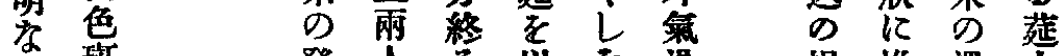
占琵 登 る

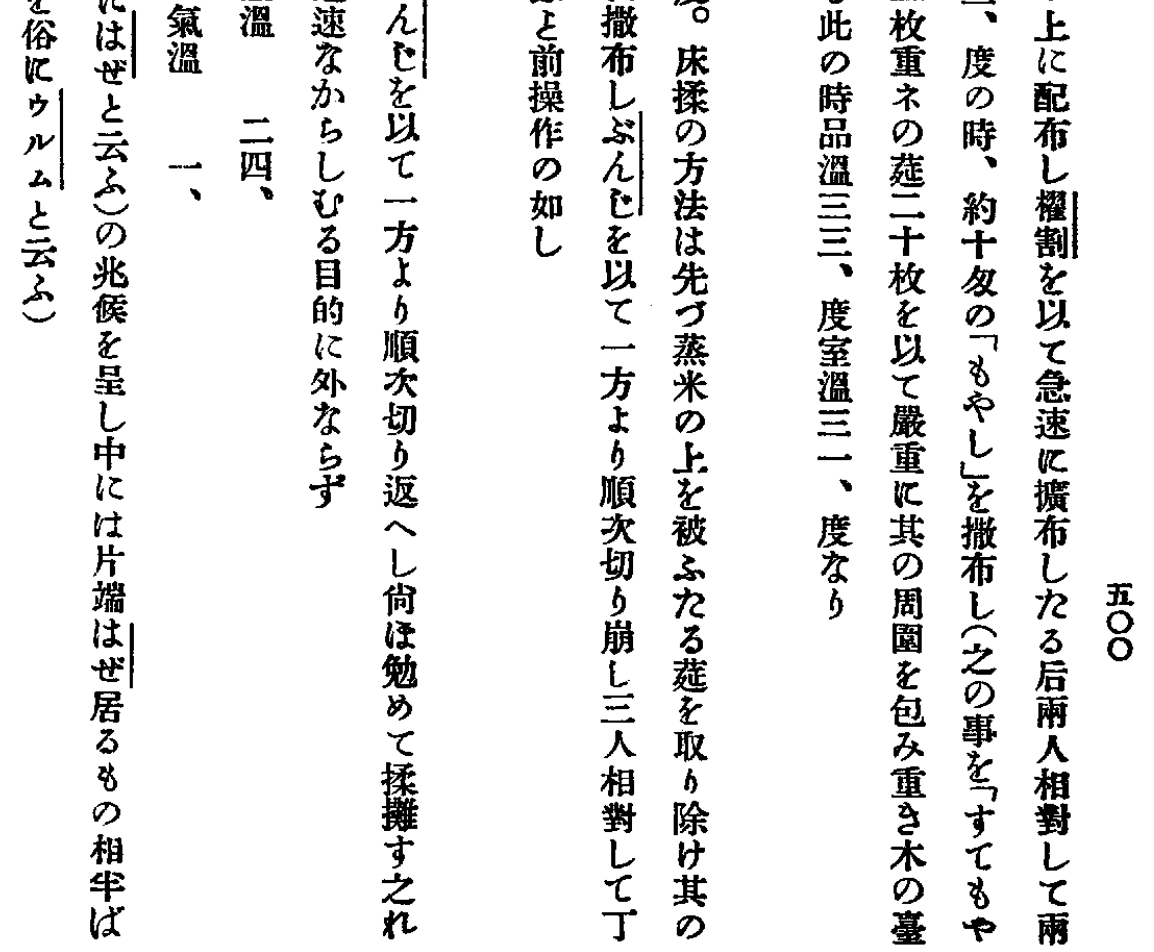

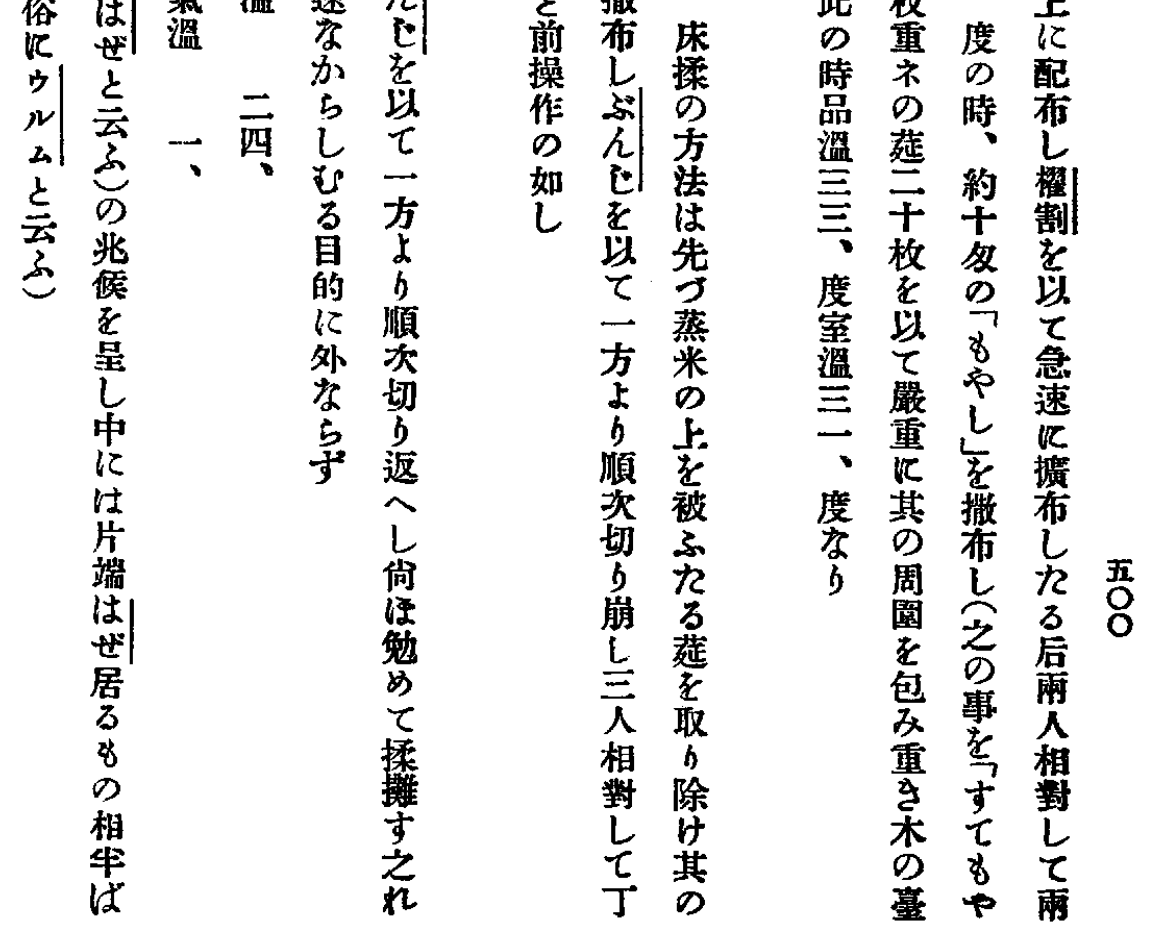


上 其

此瞿

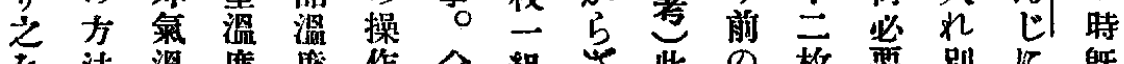
法溫度度作全粗要此枚要别飞既 制㜪は度 势：

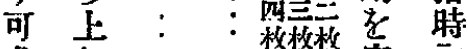
文成部 : : 䑍定初 痤し側一崩の

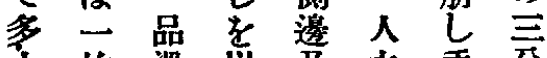

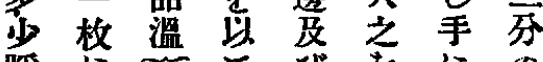

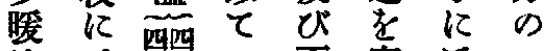
め然五一下室 $\tau-$

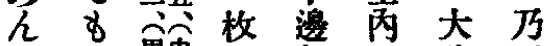

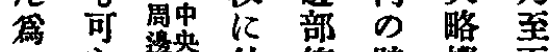

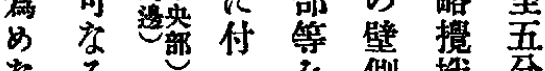

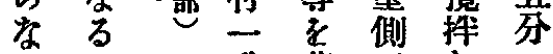
b 多蒈三儿口 而口盛至方九一

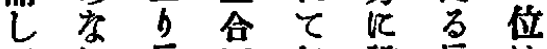
几后四包設后は

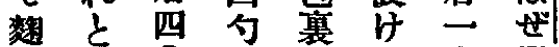
算要 突后、秀る当は当 枚江割手棚数文 至会口意認

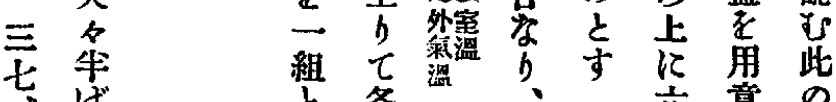
各一兵意

$\tau$ 粗 少 L

<㩭

凹 挥

L

ᄂ t2

め了

之后

れ 稢

謈

五供

○荎 虏

数 ic

蓋 持

の

步 塑

焦

居

る

党

邀

庋

守

3

8

$\infty$

如

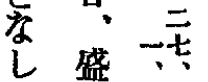

枚 ᄂ 任

加 蓋

b

亿荅

棦

כ

回際

の 餘

製

量 6

少冷

な衣

苨虞

《

因 8

るの

普は

通 好

は

江

あ右

人住

榡告

重盛飞

桝操

供葯作

筫 主

枚刑等

莫先

基 䓰

に过

重除

可

好私

置 量 


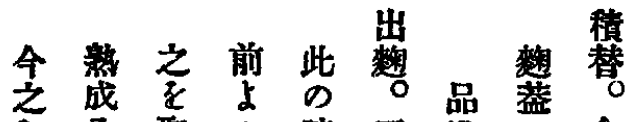

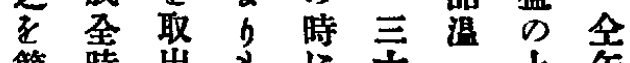

簡 時 出 8 年午

盟間卞

琞間 方

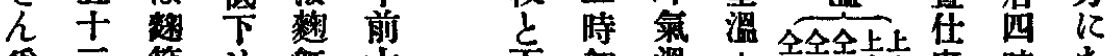

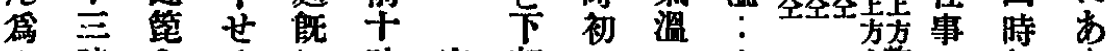

め時をる 飞時室部め

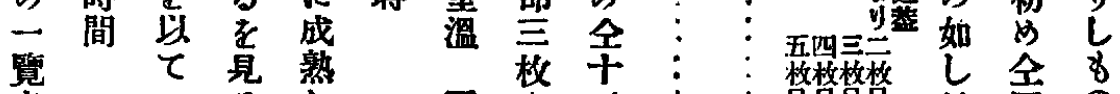

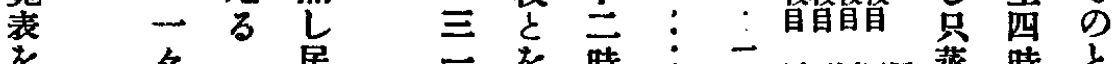

作名居

3 ऐ

$\sum$ 收

左 b

の - - 麴

如 篮

L

の 队

莚流

に 固

窲着

荅

七離

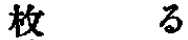

量

の

割

合

偌

室

外

運

o

廙

答

却

五

$\equiv 3$

み

蒸

米

の

狀

貌

は

此

の

特

俗

础

手

h

年

五

蒸 時 之

万

仕作 任

事の事

前大。の

市 報

赫 


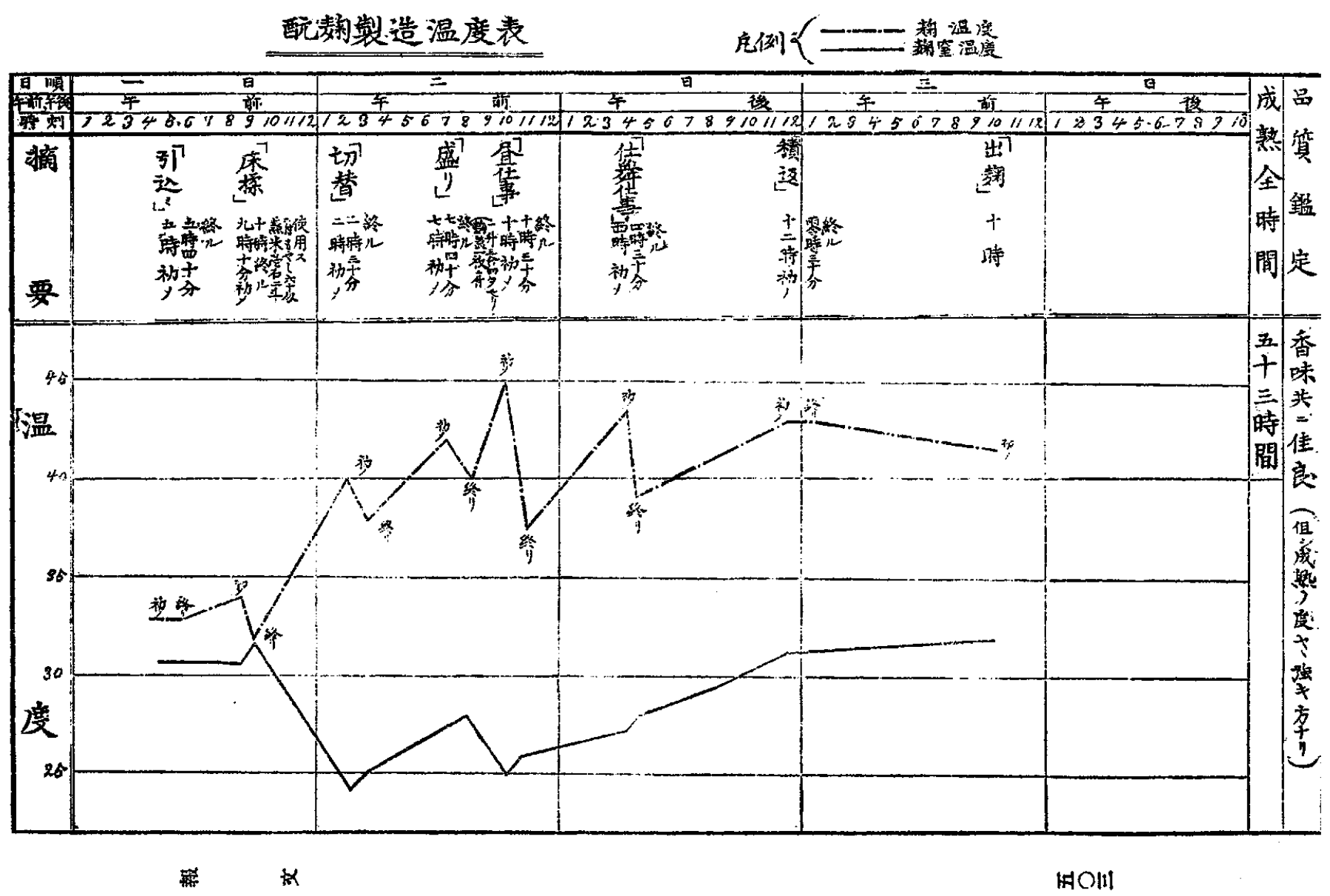


野田酒造場第五回酛数整造温度

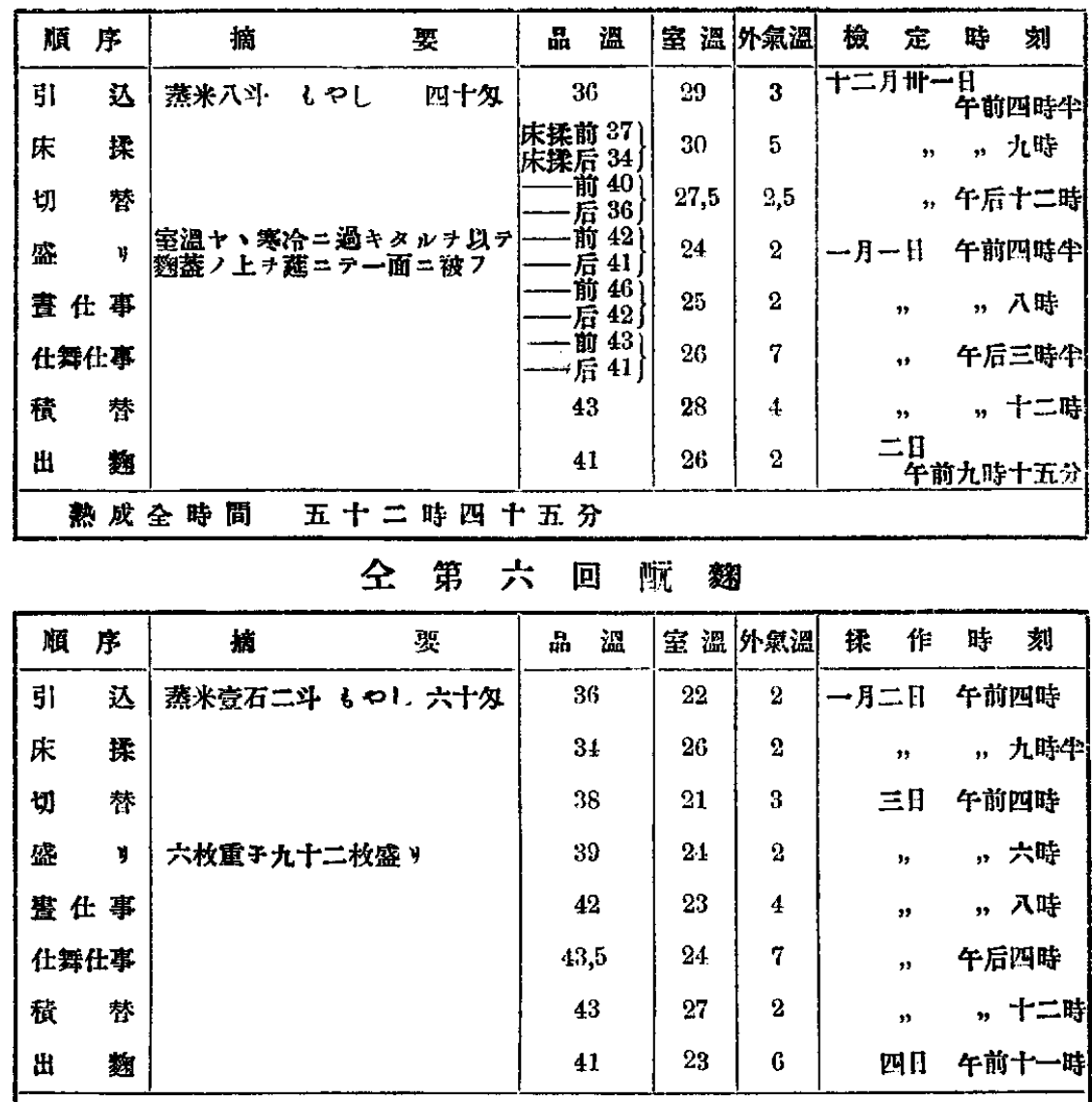

熟成全時阔五十五時間

全第 七回 酛 赖

\begin{tabular}{|c|c|c|c|c|c|c|}
\hline 崸 序 & 摘 & 品 嘼 & 穻 溫 & 外㴋嘼 & 拯 作 & 時 刻 \\
\hline 引込 & 蒸粉平 $6 \%$ L 四十为 & 35 & 24 & 2 & 201 & 午前四時坐 \\
\hline 枺正三 & & 33 & 29 & 4 & ” & ”十時 \\
\hline 如 & & 33 & 22 & 2 & . & 午后十二時 \\
\hline 盛 & 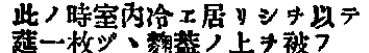 & 30 & 22 & 3 & 五日 & 午前五時牛 \\
\hline 窉 休 事 & & 42 & 22 & 5 & " & "十時牛 \\
\hline 仕:舞仕事 & & 44 & 24 & 7 & " & 午后四時 \\
\hline 積 & & 42 & 26 & 5 & " & 午店十二時 \\
\hline 出呚 & & 3S & 25 & 4 & 六月 & 午的九時 \\
\hline
\end{tabular}


全第入回酛棦並二第一回添数

\begin{tabular}{|c|c|c|c|c|c|c|c|}
\hline 㖽 芧 & 摘 & 品 溫 & 室 溫 & 外采率 & 襝 & 定 & 時 刻 \\
\hline 引込 & 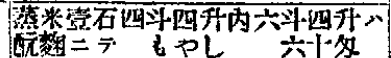 & 34 & 24 & 4 & & $\overrightarrow{\mathrm{H}}$ & 午眝:吗時牛 \\
\hline 床 モ ミ & & 35 & 25 & 4 & & , & , 十時 \\
\hline 切替 & & 37 & 22 & 1 & & 七ロ & 午前四時 \\
\hline 盛 y & 穼枚重子自十八枚㬈y & 37,5 & 22 & 1 & & $"$ & "七时 \\
\hline 眉化 事 & & 40 & 23,5 & 1 & & $"$ & "十時 \\
\hline 仕舞仕事 & & 41 & 24 & 4 & & $"$ & 午后四時 \\
\hline 皘 答 & & 41,5 & 25 & 5 & & " & , †二時 \\
\hline 出錸 & & 39 & 26 & 8 & & 八I & 手前十時 \\
\hline
\end{tabular}

\section{全第二回添 楼}

\begin{tabular}{|c|c|c|c|c|c|c|c|}
\hline 順 序 & 摘 & 品 溫 & 室 溫 & 外氣溫 & 捡 & 定 & 時 刻 \\
\hline 引込 & 熬米六斗七升 $6 p L$ 三十多 & 34 & 25 & 7 & & $\mathrm{MH}$ & 午錭五時牛 \\
\hline 休 モ 三 & & 35 & 26 & 8 & & " & ”九時 \\
\hline 切替 & & 35 & 22 & 2 & & 九日 & 午前二时 \\
\hline 盛 & & 36 & 24 & 2 & & $"$ & "四時牛 \\
\hline 害仕 事 & & 35 & 24 & 3 & & $"$ & ”九時 \\
\hline 訨钭任事 & & 34. & 25 & 6 & & $"$ & 午后四時 \\
\hline 数 & & 37 & 25 & 2 & & 十日 & 竹前四時 \\
\hline
\end{tabular}

熟成全時間四十六時間牛

\section{全第三回仲 添 数}

\begin{tabular}{|c|c|c|c|c|c|c|}
\hline 順 序 & 㨝 & 品 温 & 窒 温 & 外蔌滥 & 检 定 & 時 刻 \\
\hline 引込 & 蒸米五斗六升 6 PL 二十五勿 & 34 & 27 & 2 & 一月九日 & 个前五時 \\
\hline 底モミ & & 35 & 24,5 & 3 & " & ”十曗 \\
\hline 盛 》 & & 31 & 24 & 2 & 十日 & 午前五時 \\
\hline 琶任事 & & $3:$ & 23 & 2 & 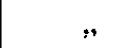 & ”八時牛 \\
\hline 仕舞仕事 & & 38 & 24 & 9 & , & 千后四㭙 \\
\hline 出魏 & & 37 & 24 & 3 & , & $\because$ 十二時 \\
\hline
\end{tabular}




\section{全第四回 (添、仲、留) 一三理粼}

\begin{tabular}{|c|c|c|c|c|c|}
\hline 順 序 & 撴 & 品 溫 & 空 溫 & 外䌽溫 & 搨 定時 刻 \\
\hline 可沉 & 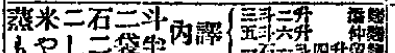 & 35 & 24 & 3 & †日 午前六時 \\
\hline 枺モミ & & 30 & 23 & 4 & ”十時 \\
\hline 盛y & 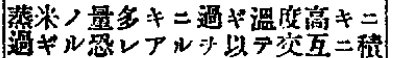 & 32 & 22 & 2 & 十一日午前四時 \\
\hline 蔫 仕 妻 & 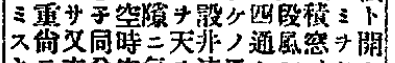 & 33 & 24 & 1 & " 七時 \\
\hline 仕舞任票 & 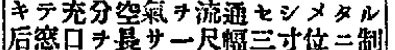 & 39 & 28 & 6 & 4后四時 \\
\hline 出微 & 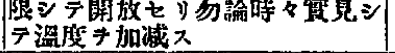 & 38 & 23 & 0 & "十二时 \\
\hline
\end{tabular}

\section{全第五回（添、仲、留）竭}

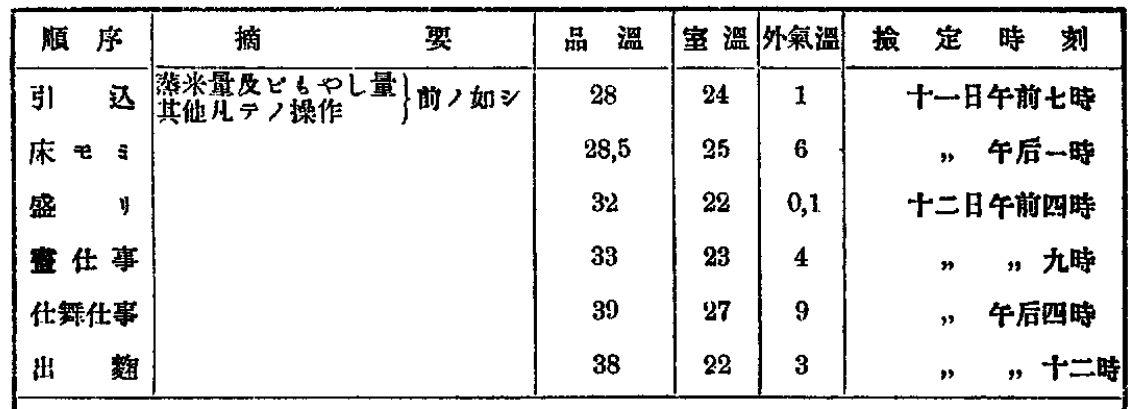

熊成全洔間 四十一時間

全第六回（添、仲、留）数

\begin{tabular}{|c|c|c|c|c|c|}
\hline 唯 序 & 墒 & 品 温 & 室 温 & 外氯涸 & 撿 定 時 刻 \\
\hline$引$ 引 & 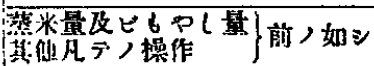 & 32 & 22 & 2 & 十二日午前七時 \\
\hline 床 $\approx \equiv$ & & 32 & 23 & 6 & ” 午后一時 \\
\hline 盛 y & & 35 & 25 & 2 & 十三日午的四時 \\
\hline 整訨事 & & 37 & 25 & 6 & ”十時 \\
\hline 仆漂仕事 & & 39 & 24 & 8 & ， 午后四時 \\
\hline 出類 & & 41 & 31 & 7 & "十二時 \\
\hline
\end{tabular}

整战全時間四十一時简 


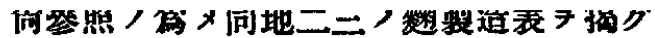

（a）崔䊝制造溫度表

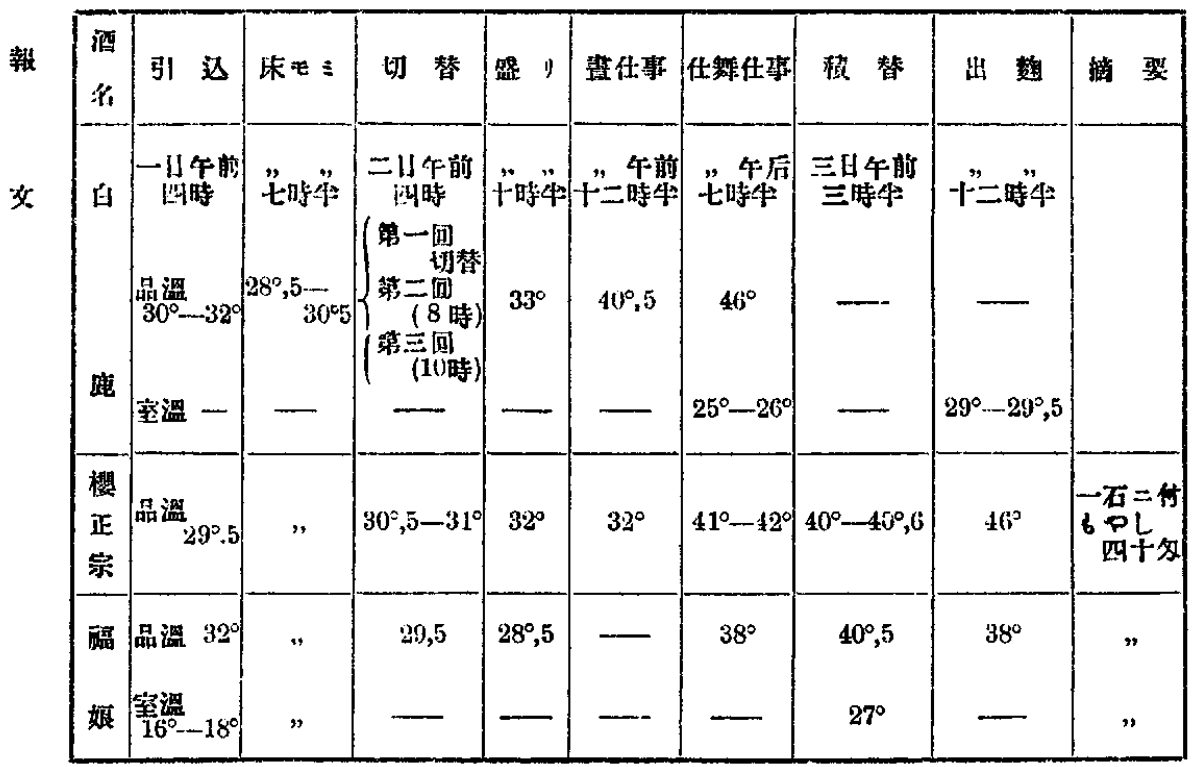

（b）本野酒造埧酒翁塒数製造溫度表

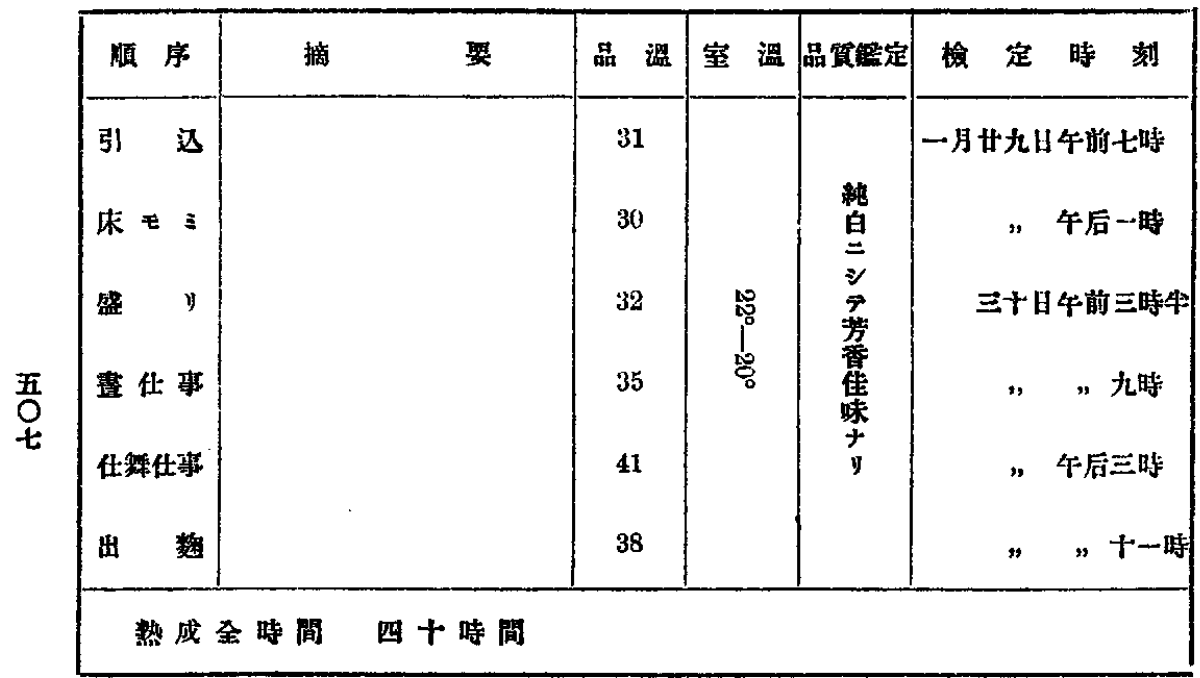


㳡园 (5) 澤 昇 (4)

飞之(3)を外 (2) 抵る(1)

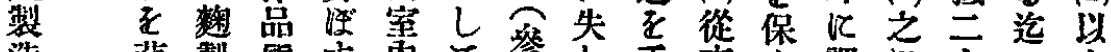

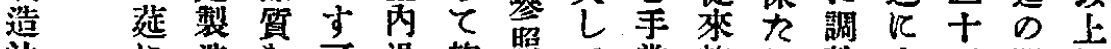

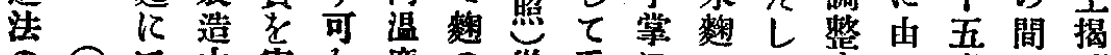

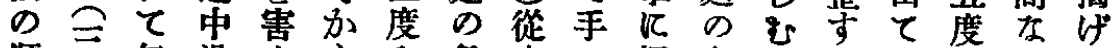
順导包温守ら各來江握良るる見㐫れた

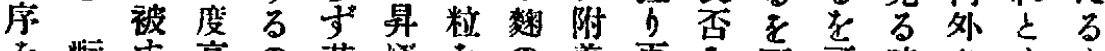

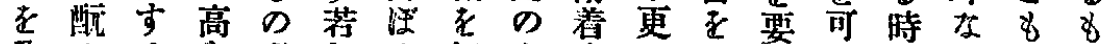

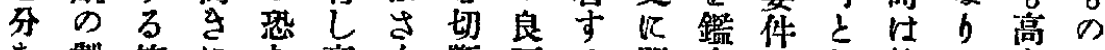

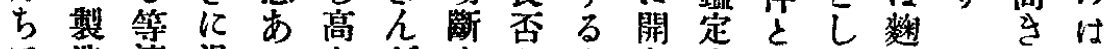

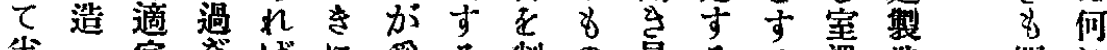

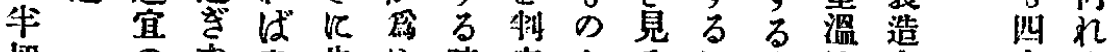

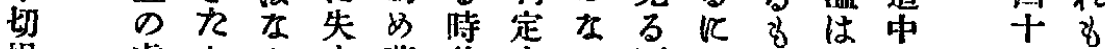

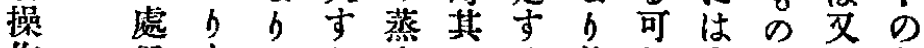

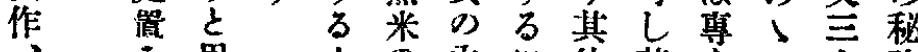

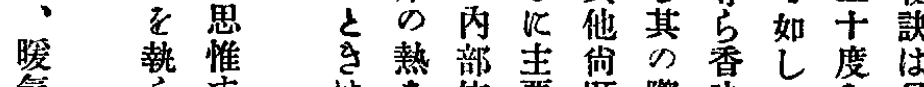

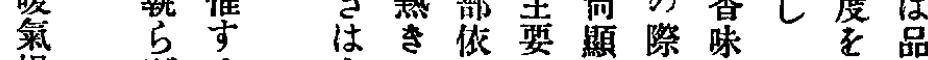
操 る 之然の微輕之

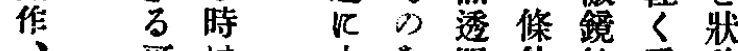

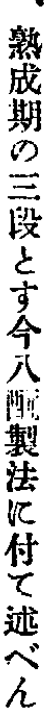

可忧

山老明件的手貌

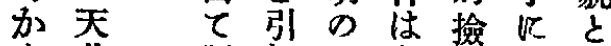

成占製込状色香威に

期 寸゙の 造さ態澤並じよ

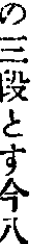

待

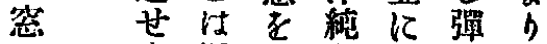

占通保白酸力た

開机例口性为机

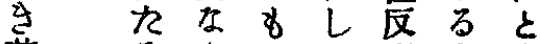

落るちのて應を市

乙 䴹とを芳主良簡

低 雄良香試し單

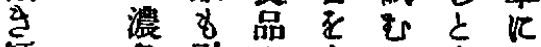

傾色引と有方方し

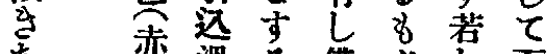

あ赤溫る㯵必洏

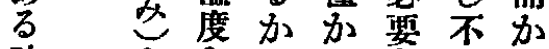

時委如化学良名

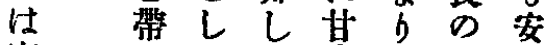

空

z

加

珹

來 决

ね素

元

z

b)

亭

且

延至

的

るる

且

五

感

残

觪

清度

D

周

酒 以

() 上

㜍 方

は法

堅注

L 少

超 溫

之

L $L$

\$ $\tau$

ず决

$\mp \mathrm{L}$

度四

t

低 五

下 度

せ 以

L 1

め

寸゙昇

ᄂ

$\tau$ 主

常 可

比

干

二 常

度

占最

b 高

三 温

五 健

度 性

考

超 造

充

ず标

低 し

齐

83

報

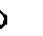
文 
蕃合

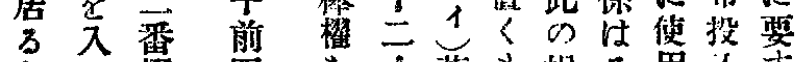

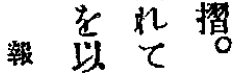

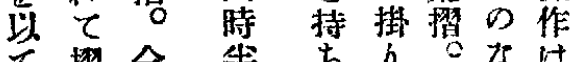

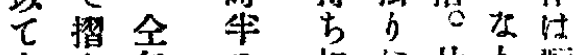

容多午 0 相飞甘b唒

文

竟后捡一て分此杜

分分溫致全日达

$b$ 多特外室品 $L$ 刻年操後

方上多室品七立前作

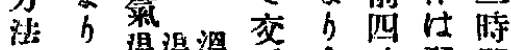

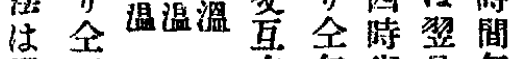

通㤗左午手香每

例時右前年法

一迄江士前施

万

D四五擤時

年 门主二

切

桶

$\frac{12}{\bar{x}}$

相

㩆

ᄂ

行

勇

摺

o

特

k

此

要

视

吾壮

恶液

孚

化

ᄂ

稀

㹈

$\varepsilon$
四行

時 声

运当

《 है

前の

后飞

五 ᄂ

回

施 棒

行櫂

寸 1

金装

全 少

<D

满年

is $i$

揞云

相

泥對

獎 ᄂ

r

禁众

は

菻

櫂

他

の
櫂 切

四心

揚 の
世 ᄂ

乙雨既

蒸手定

来に原

江て量

一数学处等

畫回前氮

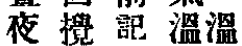

浸柈》：

清混混

合合七七

後守覑

合 $k$

朝從

時 七

䓜

L 名

げ職

䔎 I

V $k$

摭

$\tau$ 布 操

本

切市

桶 b像

D学

物者成

料 8 澺

类

數 猌

回讨礼

㨨 今 位

汼朝召

七年亲

$3+$ 四

后時枚

手牛少

にの 牛

$\tau$ 出 切

な來桶
没赹蒸翟

氶㐘込

温温温

五九吉

五五年

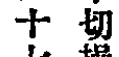

七 操

仕 星

住午

後

四

封

$+$

弥

着

手

全

西

時

四

$+$

分

終 


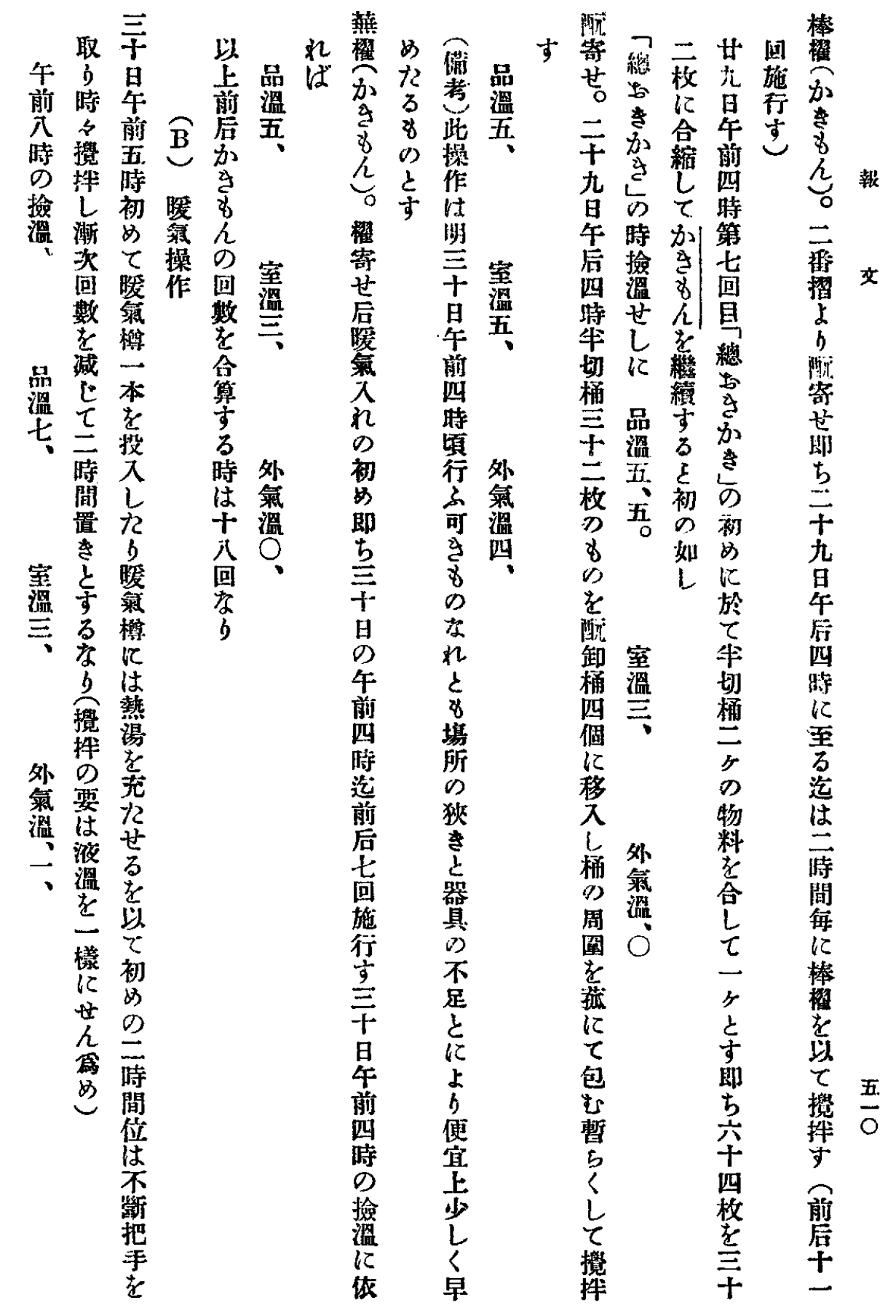




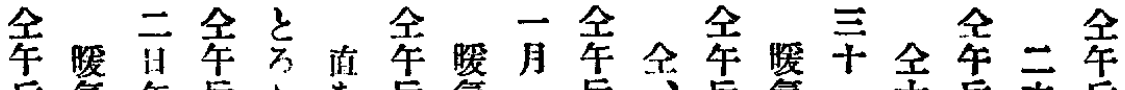

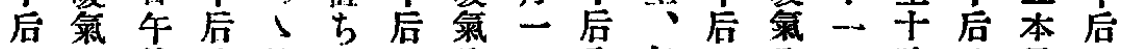
一入前入泡に一入兲入午一入百時八目 $\rightarrow$

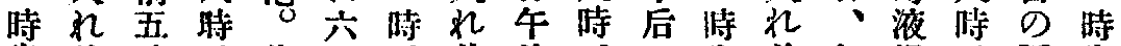
牛前洔、此本、前前、牛前午溫、昽本

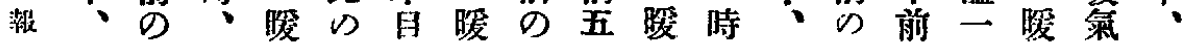

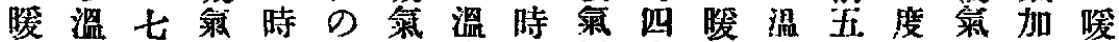

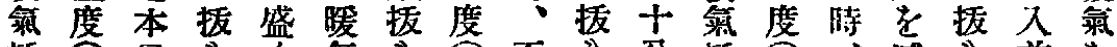

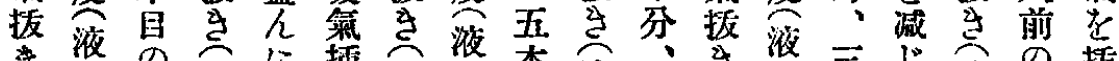

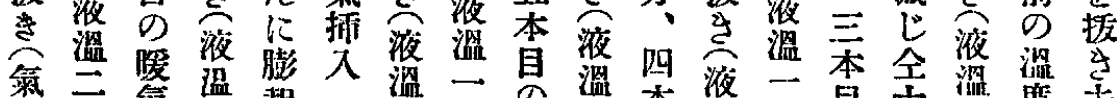

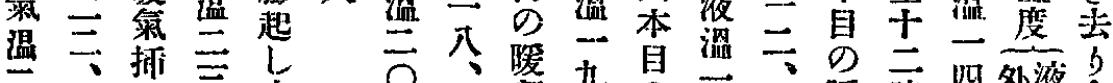

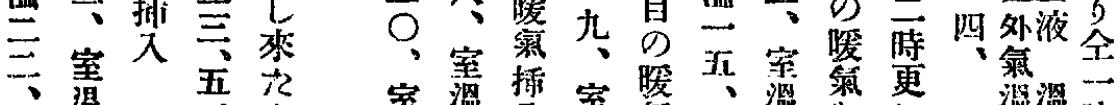

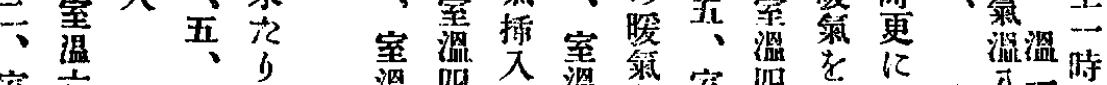

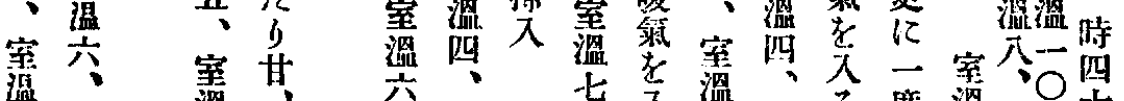

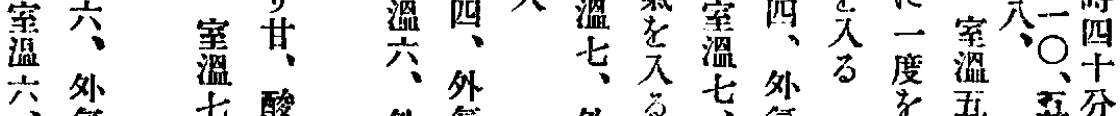

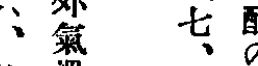

外 溫

繁 然

温亏氮暗

芯相特

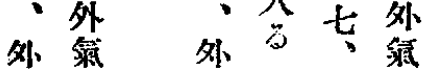

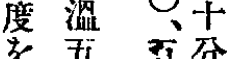

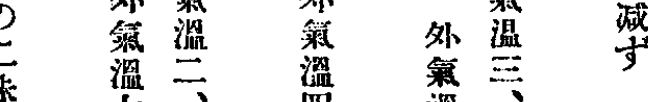

I. 恶分

志心四㵋

に 


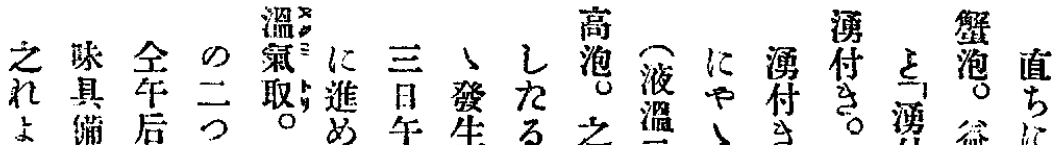

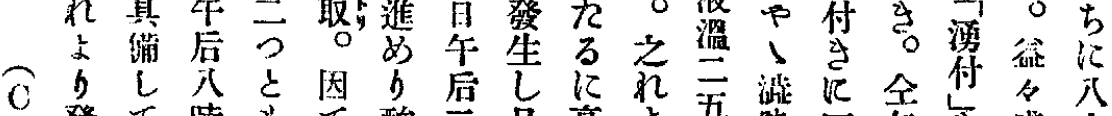

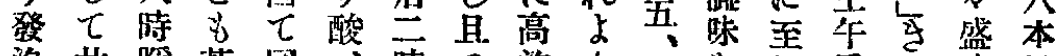

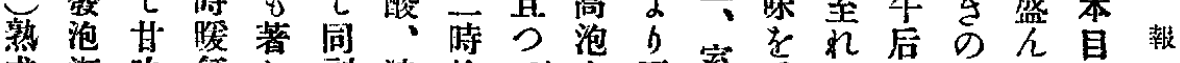

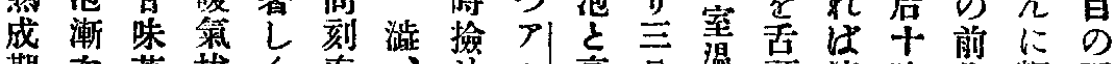

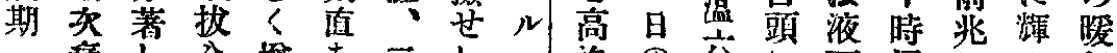

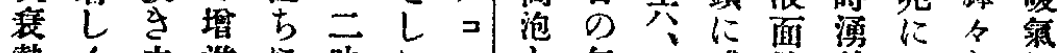

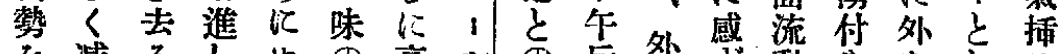

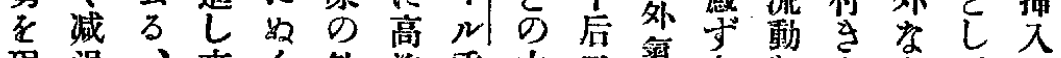

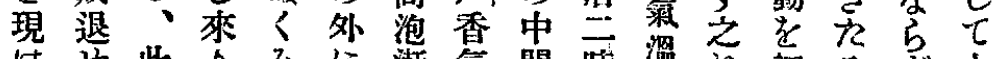

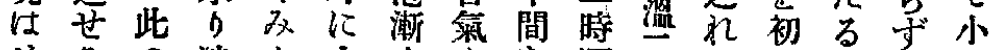

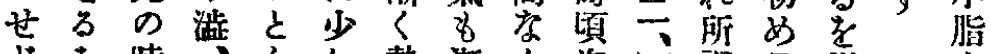

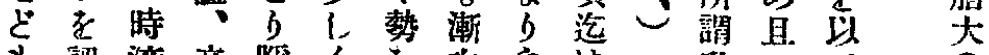

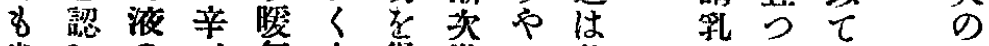
份むの、氣幸得進与其味泡暖粘 二且牀 $の \rightarrow$ 味它微

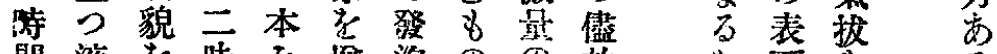

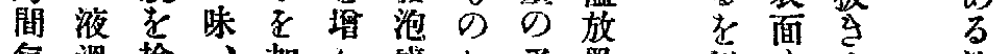

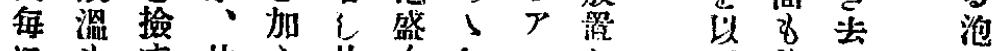

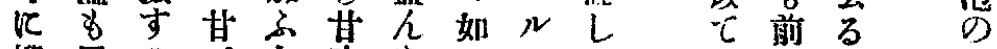

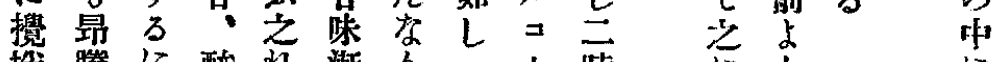

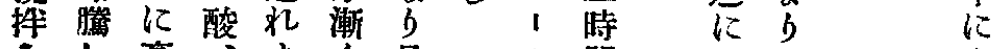

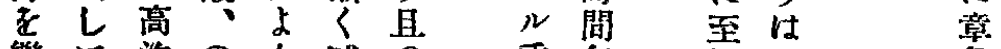

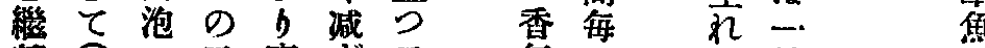

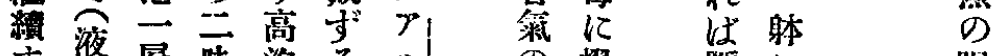
す夜層味萢る心 澹考强 \& 三勥瓷盛の 室を䨛 如香

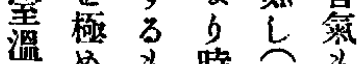

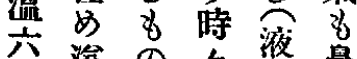
、溢の名㳑舅

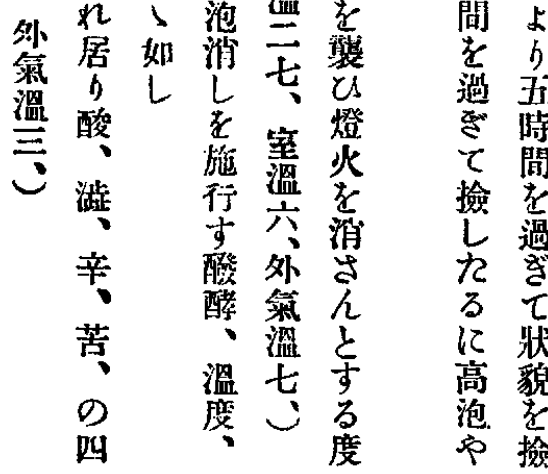

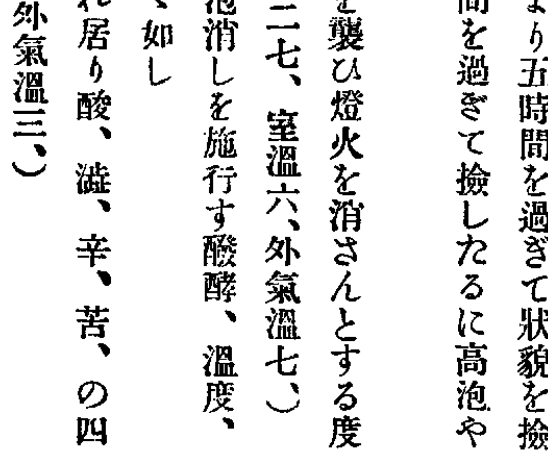

の櫂暧に 簿入蔡光 散撚老輝 す挷㧞 茰 寸 に活 三 付 恉 य

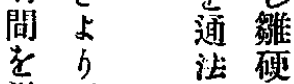
出度 眼 命 如 a 天 考察察 ᄂ 泡 沸 文發 寺将泡

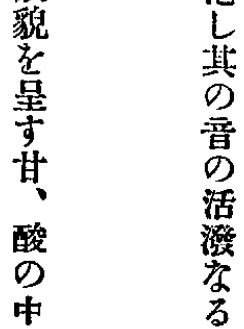
五 


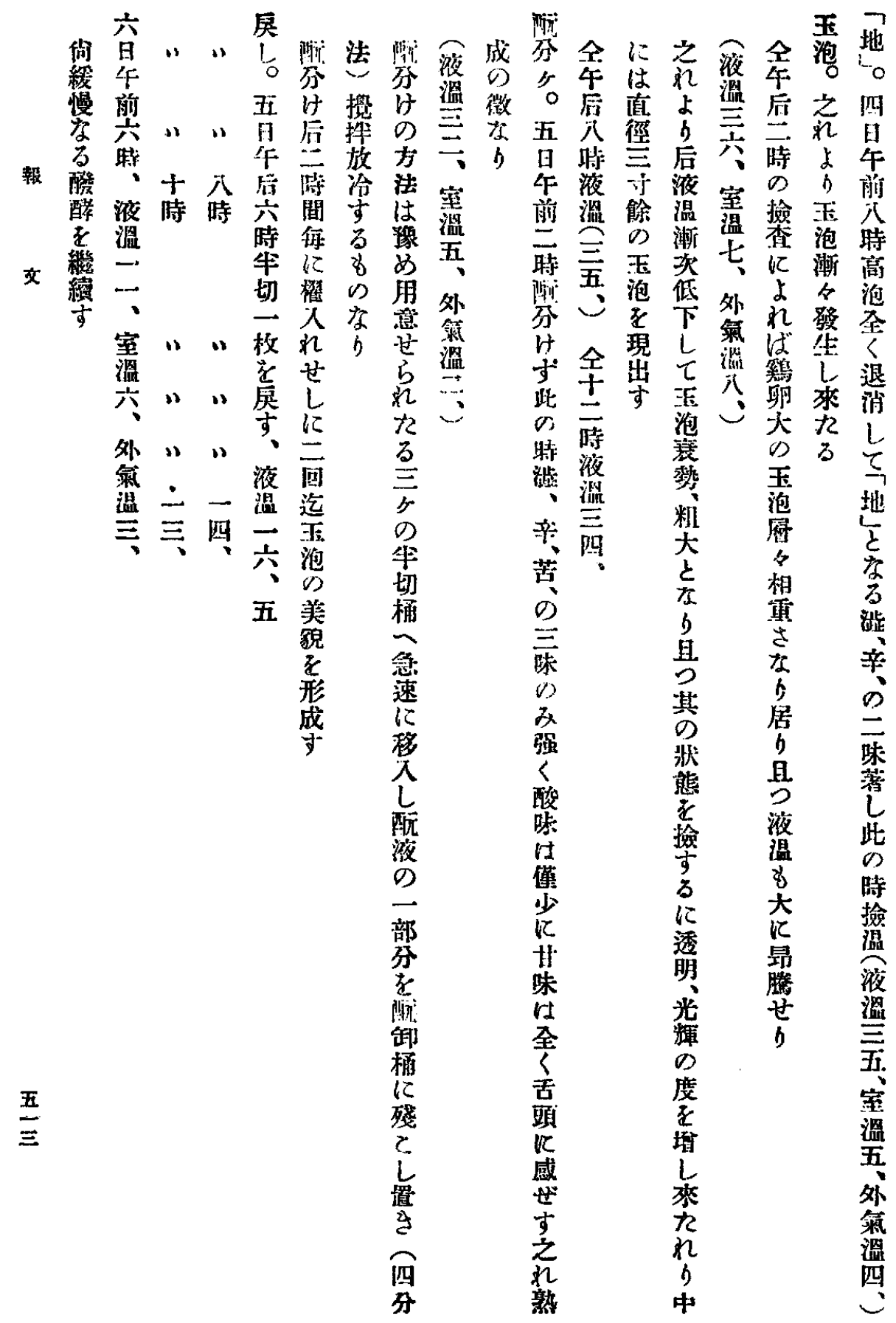


酛 製 造 法（第一表）

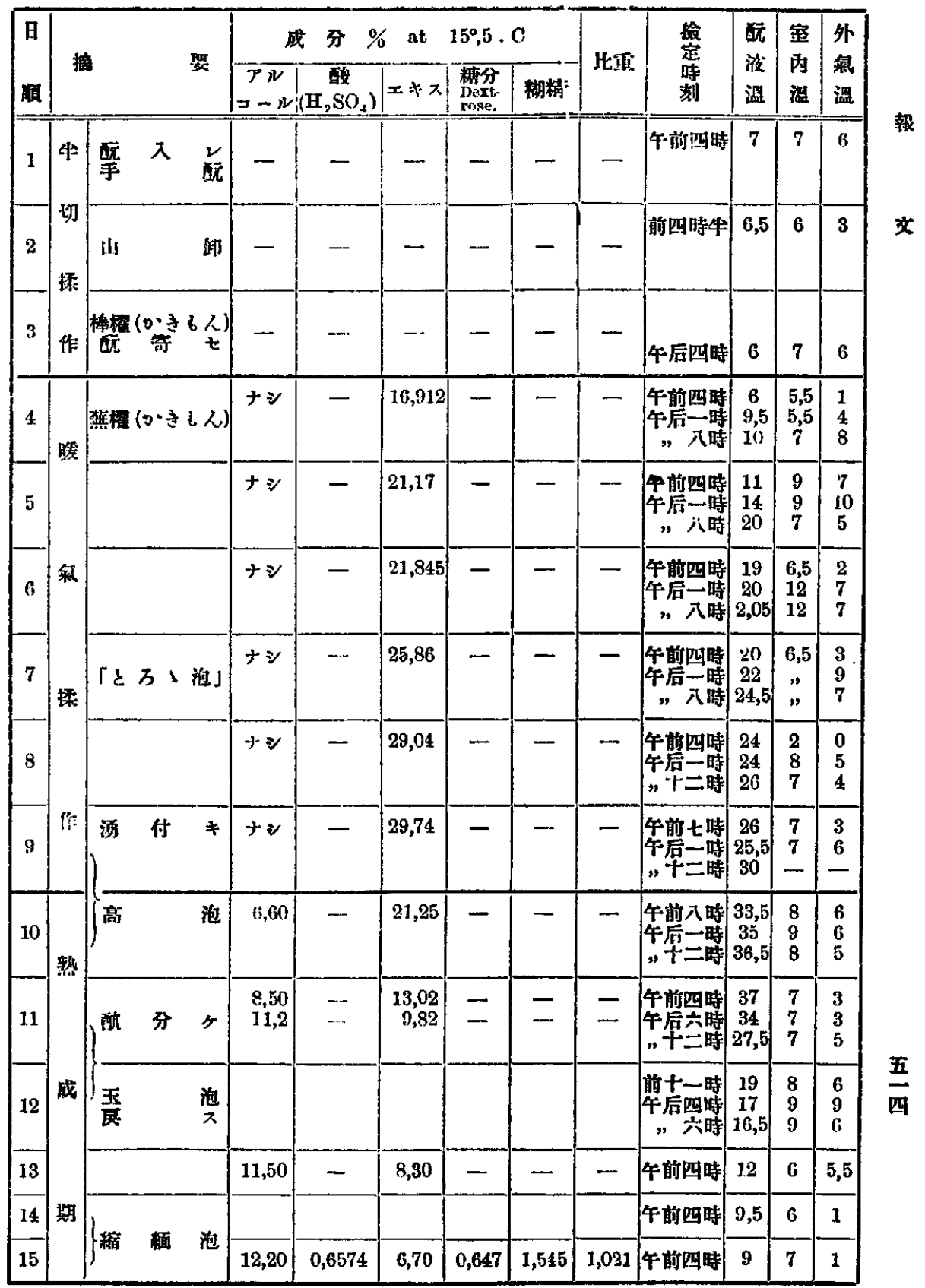




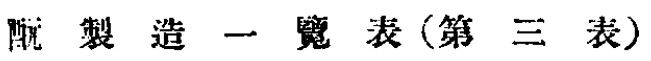

\begin{tabular}{|c|c|c|c|c|c|c|c|c|c|}
\hline 酒名墒罗 & 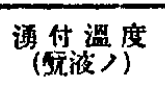 & 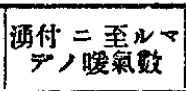 & 休 & りり珻作時問 & 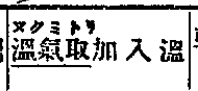 & 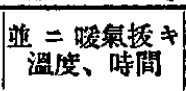 & 酰 分 & 层 & 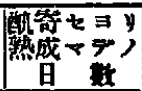 \\
\hline $\begin{array}{l}\text { 葱 } \\
\text { 萦 } \\
\end{array}$ & $21^{\circ} . \mathrm{C}$ & 八九本目 & 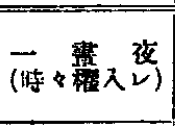 & 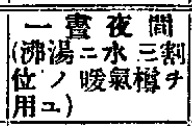 & $24^{2}-25^{\circ}$ & 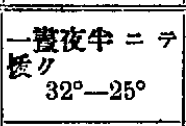 & $\left|\begin{array}{c|}\text { 時任位 }=\text { テ } \\
35^{\circ}-36^{\circ}\end{array}\right|$ & $26^{\circ}-27^{\circ}$ & 10 日 \\
\hline 艮 & $21^{\circ} . \mathrm{C}$ & 八九本目 & 二 基 液 & 二 慧 & - & $34^{\circ}$ & $\begin{array}{c}\text { 六七時間 }=7 \\
31^{\circ}-32^{\circ}\end{array}$ & $\begin{array}{l}8-12 \text { 時間 }= \\
\text { 于扈 }=\end{array}$ & - \\
\hline $\begin{array}{l}\text { 枈 } \\
\text { 長 }\end{array}$ & $22^{\circ}-22^{5}, 5$ & 八本 目 & 一㹂 夜 & 一 䇺 & 一 & $34^{\circ}$ & $\begin{array}{c}\text { 十特間 }=\text { F分 } \\
32^{\circ}, 5\end{array}$ & $\left\{\begin{array}{c}\text { 約一日 }=\text { 二两 } \\
x \quad 15^{\circ}, 5\end{array}\right.$ & - \\
\hline 䇴 & $22^{\circ}-22^{\circ}, 5$ & 七本 目 & 一 ${ }_{222^{\circ}, 5}^{\text {菣 }}$ 夜 & $一 \frac{\text { 售 }}{26^{\circ}, 5}$ 夜 & - & $\begin{array}{c}\text { 一㱐夜 }=\text { テ技 } \\
34^{\circ}\end{array}$ & $\left\{\begin{array}{l}+\lambda \text { 時間 }=7 \\
34^{\circ}\end{array}\right.$ & 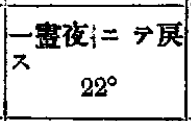 & - \\
\hline $\begin{array}{l}\text { 白 } \\
\text { 麇 }\end{array}$ & $24^{\circ}-25^{\circ}$ & 七八本目 & 一貫夜 & $-26^{\circ}$ 畫 $28^{\circ}$ 夜 & - & 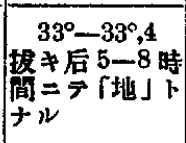 & 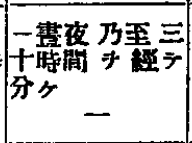 & $"$ & - \\
\hline 白 & $24^{\circ}-24^{\circ}, 5$ & 七八本目 & 12 時 閒 & 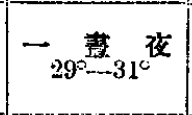 & $31^{\circ}-31^{\circ}, 5$ & $\begin{array}{c}33^{\circ}, 5-34^{\circ} \\
\text { 最甞 } 34^{\circ}-35^{\circ}\end{array}$ & $\begin{array}{c}24 \text {-30 時間 }= \\
29^{\circ}, 5\end{array}$ & $\begin{array}{c}10 \text {-24 時间 }= \\
\overline{1} \text { 总 } \\
14^{\circ}, 5\end{array}$ & - \\
\hline 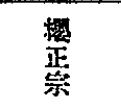 & $20^{\circ}-21^{\circ}$ & 八 本 目 & 18-24 時閴 & -- & $25^{\circ}-25^{\circ}, 5$ & $\begin{array}{c}\text { 营夜 }=于 \text { 括 } \\
87^{\circ}\end{array}$ & 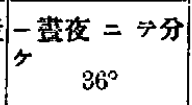 & 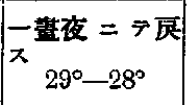 & - \\
\hline $\begin{array}{l}\text { 詖 } \\
\text { 辝 }\end{array}$ & $26^{\circ}$ & 共七本目 & \multicolumn{4}{|c|}{ 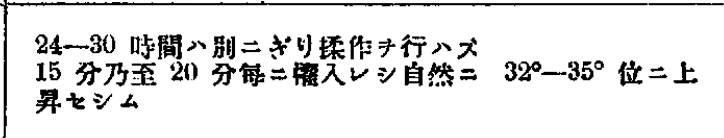 } & 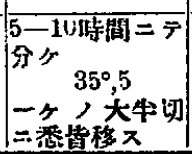 & $\left|\begin{array}{c}\text { 三畫夜 } \\
\pi \\
15^{\circ}\end{array}\right|$ & - \\
\hline
\end{tabular}


熟成 盶液 分析表

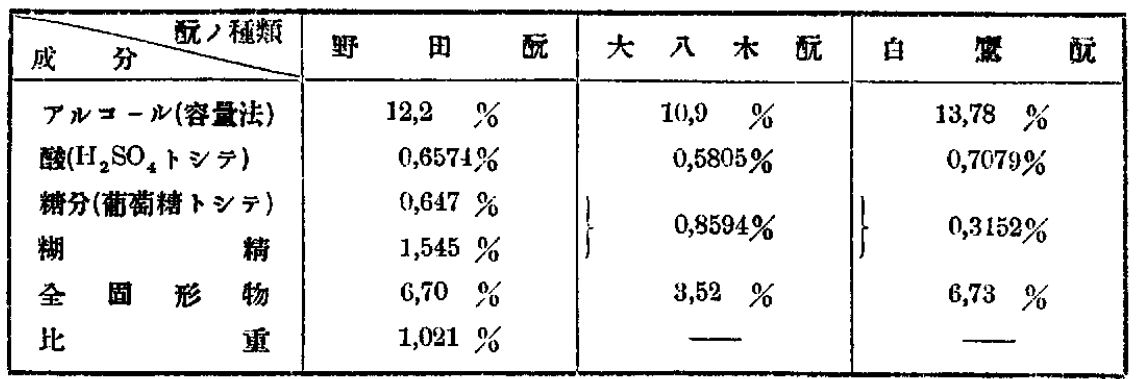

哌

文

にを利れ (2) 㜔をつ外 (1) 次家次

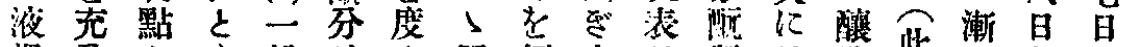

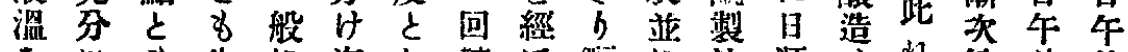

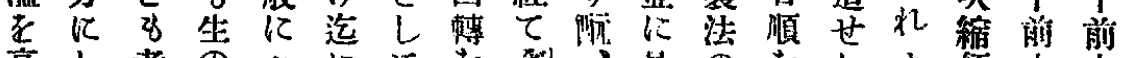
高し 考 の

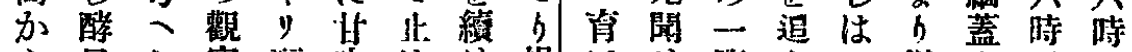

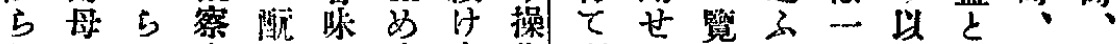

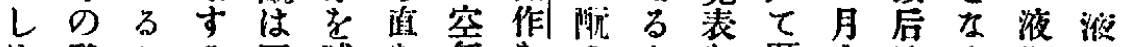

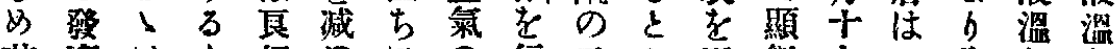

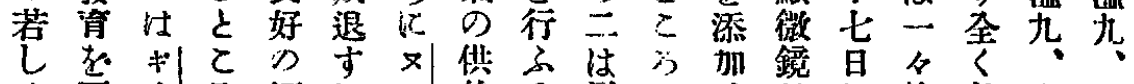

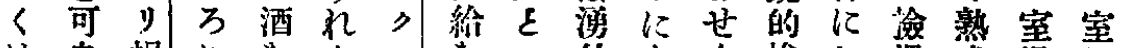

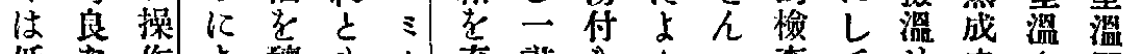

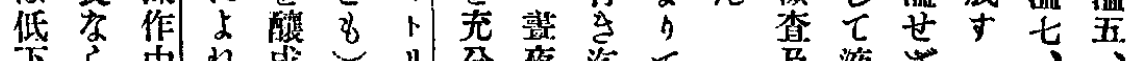
せ しひ湓必 的范占代 且将焉仕 $\supset$ 将 $\mathrm{O}$ L

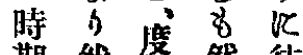
期然度然㖗

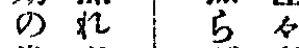
當を!。臂 要吾䔏 先若五它酒 すし队索 万此外】造 境の $V$ 如 る 合原調 $L D$ に 則 節 加 管

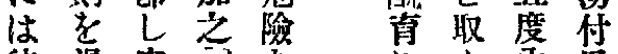

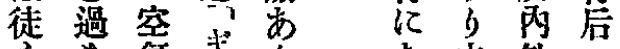

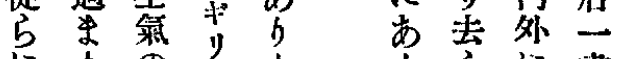

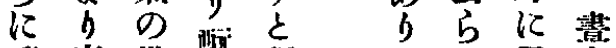

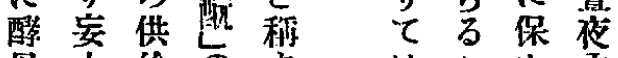

母引給の卞はす古丙

温 $三$ 主

行度素なる

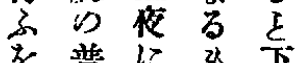

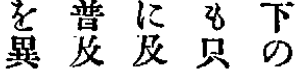

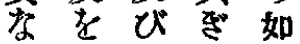

$b$ 圆 其 b $\mathrm{L}$

之 5 間 阮 寸甘液 に

る陈滥あ

の

み㱠三

h十杜

陫五活
蚠㭛

交百

試五

五向

放の

万事

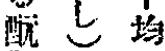

製に

造声

表濢

揭识

げ 箅

侀䢁

せ す

他兑

の酛

酒江 
(6) (5) (4，す百沓味 (3) の

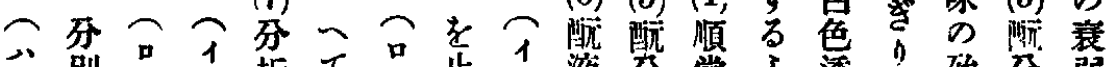

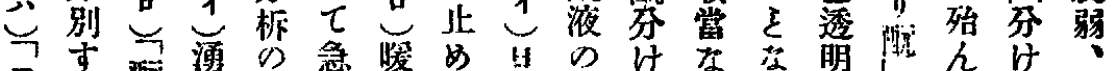

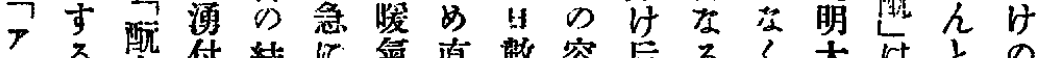

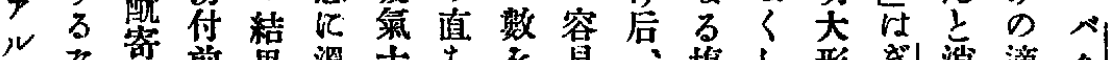

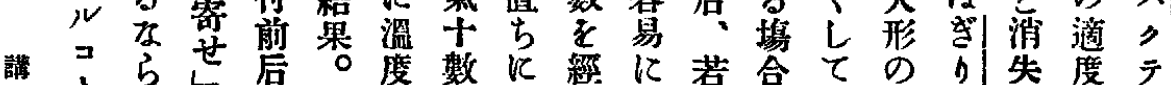
$15 \leftarrow$ 后。度數に經に若合ての方失度テ

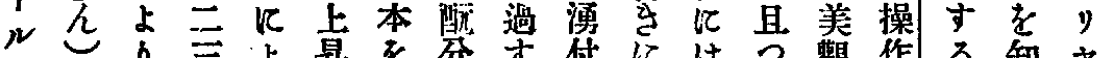

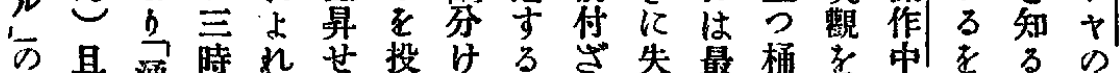

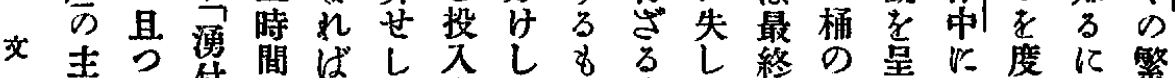

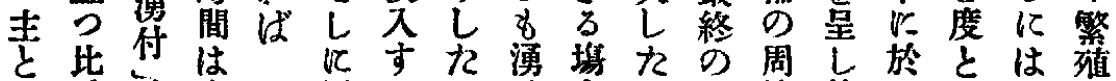

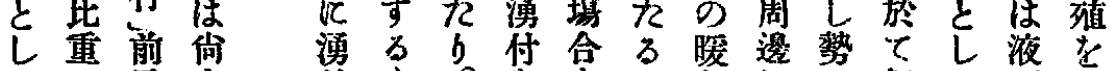

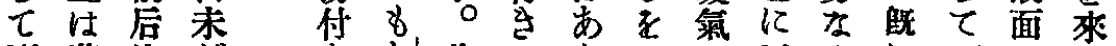

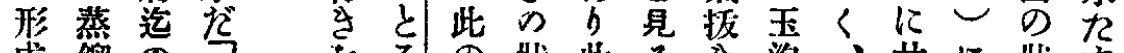

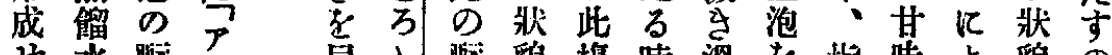

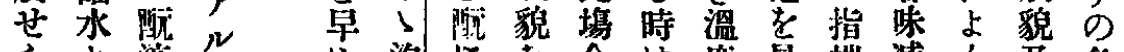

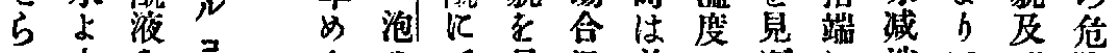

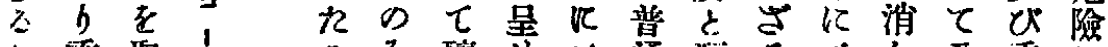

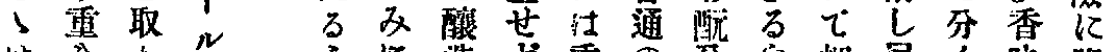

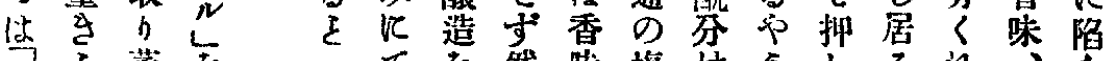

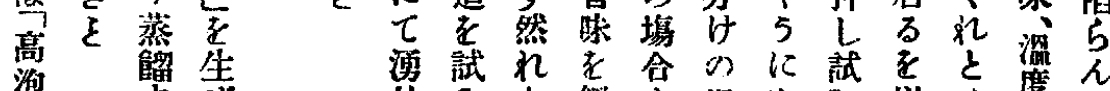
萢篮全

点望

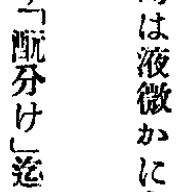

白

間濁

倠整

各製

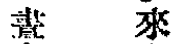

䋇多

两 天

五深文

$\frac{\mathrm{t}}{\tau}$ 或

王

泡整

叶脂

は 括

$\curlyvee \quad$ 然

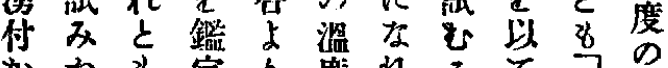

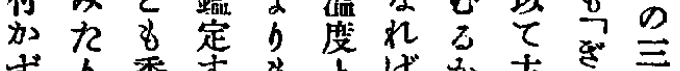

ず

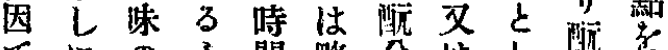

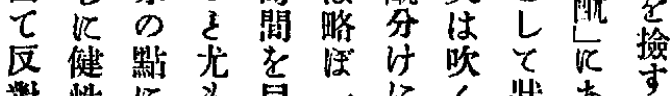

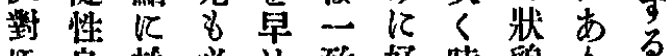
民良於必め致好時貌 $\frac{b}{c}$

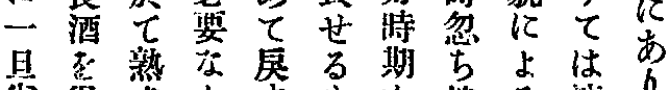

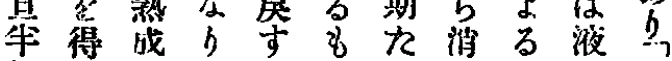
切方院学可のb先の酒青

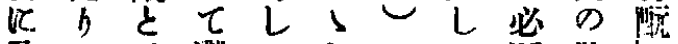

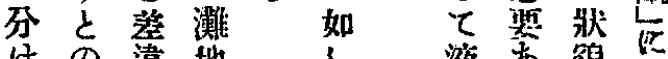
け違地 L 液あ貌市

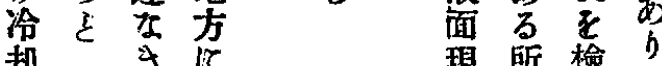

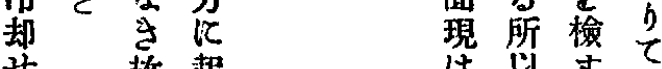
世故起 は以旦は L 之 め れL 更偟

泟 $\tau$ 例

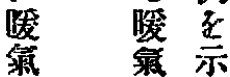
加箖导

设等禁 整 b妾表

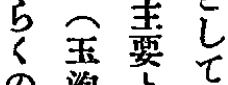
の萢年香 埋狀是味 汥貌犯甘 
(8)

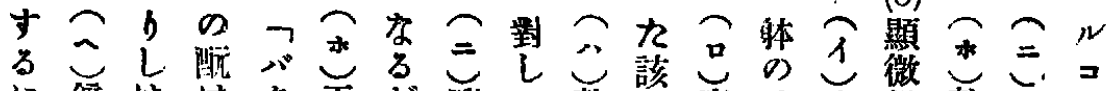

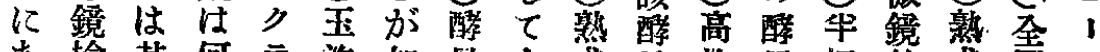

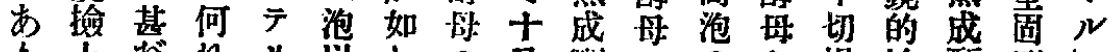

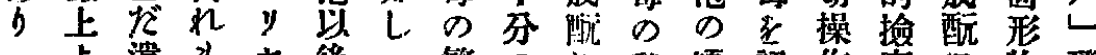

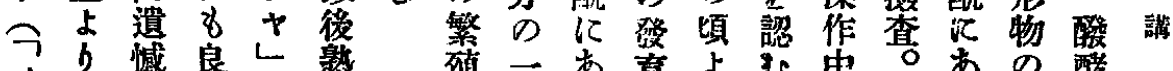

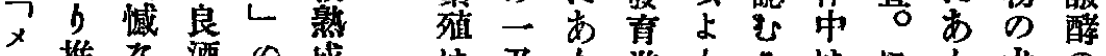

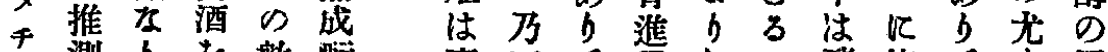

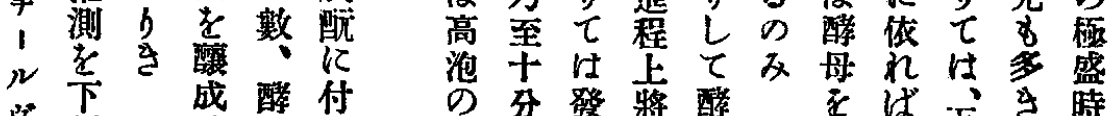

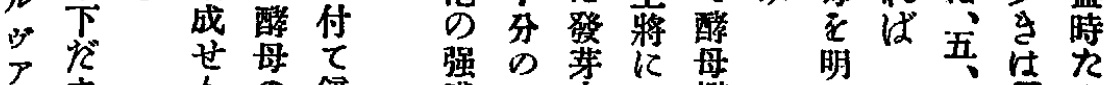

アす

1 時 湩 數 鏡

盛 二中然檻

レは 在恋す

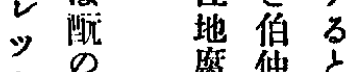

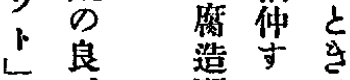

ら不勘方注

\%良家

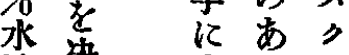

溶瓷掟 方

液定专至》

に 3 ह

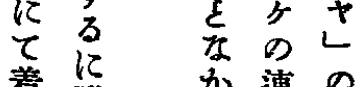

倨应のる 圆

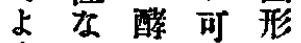

b b 母

玉 减的学

泡少の b

の しか著

初学吉

期㧓他了

に 立昌增

於老要

裹精守

着唯台連の

色唯方接種

せ市的類

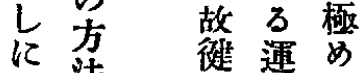

老法性運動て

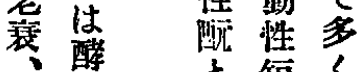

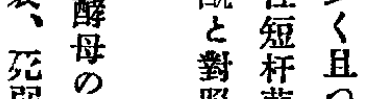

弱老

䤃䎕

照菌

臹

し

比多の

は死

較 繁

容の

的老字

暴 数

鏡見驚

$\leq 0$

撿るく

尤

の榅る

8

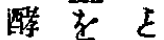

盛曹要㤝

h 多守事

小實

れ 存梦

है

占

8

is

$>$
7
$y$
+1

$\varnothing$

增

殖

は

寧

寸 然 程

ろ

着多号れな

玉

色少文主

泡

世老

क क

の

万 檢

得此次

其

割

合 $\tau$

割

發瀁

芽液

中

$\infty$

8

明

吾九

飞查

等

最

中

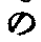

I

孤

草 然

醉

时

k

加

将
果

Ф

䋚

加

江

認

得

$\Xi$

视

c

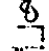

答

世

这

涌b

七付

○

卜前

间居

外 三

の三

全 時

固 間

形

物處

子水

保证

留之

于 8

る 決

\& $L$

D

k

坐

透

明

0

牴

立

小

形

醉

母

上若

如 $\mathrm{O}$

ヘ

七

v

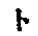

菻

超

ゆ

$\frac{\pi}{\pi}$

仕

枽

亿

發

i 


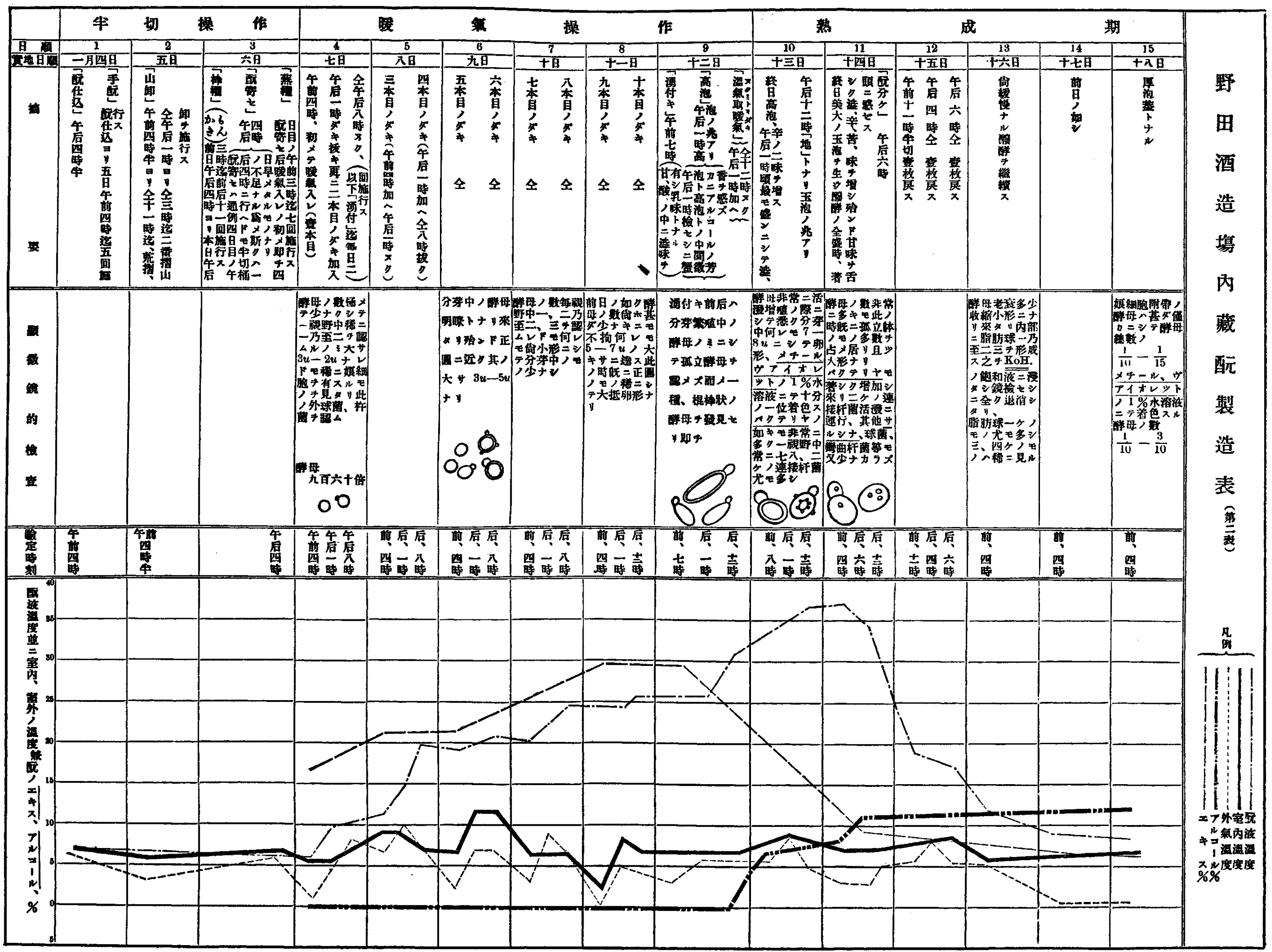




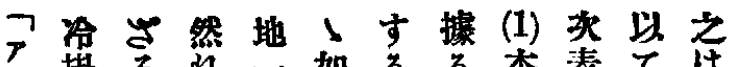

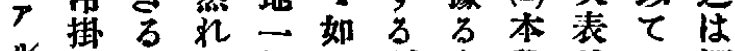

Nは它般し吕8 段亚一酒

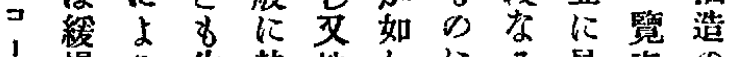

人慢亏生熱地しにる鼠裴の

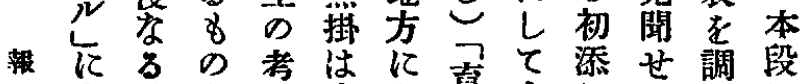

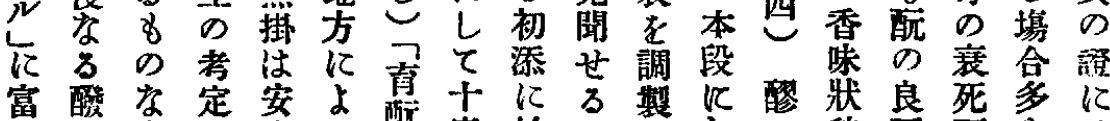

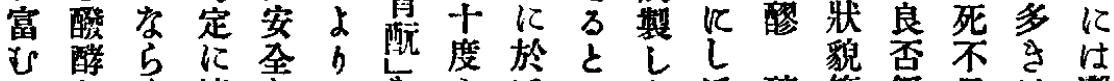

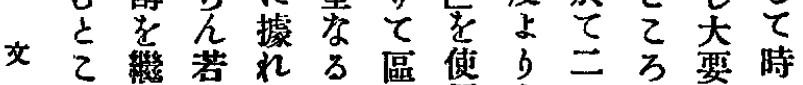

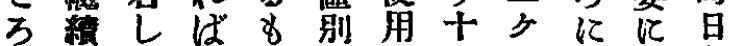

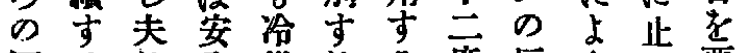

酒万狆全排方度区b要

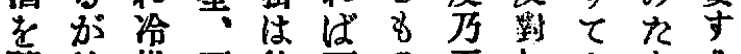

醇故津不往西至し考b方

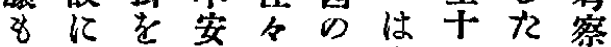

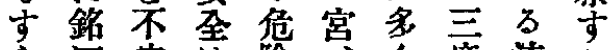

酒安庄險人度流る

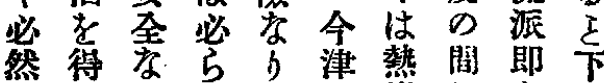

之鏡方角亚

醕 等鑑足 柱灘

定に徙地

造參はあ加方

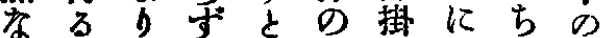

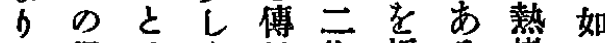

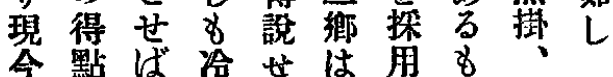

醍獨 $b$ に

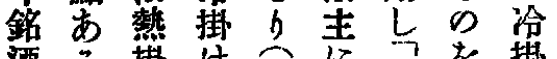

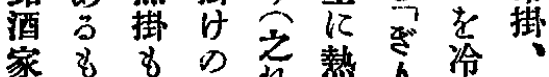

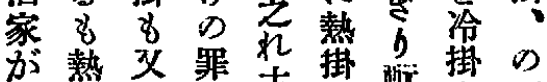

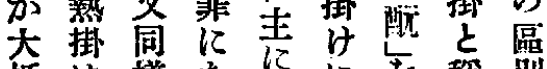

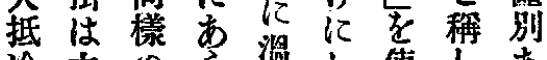

椧之心怔し使しあ

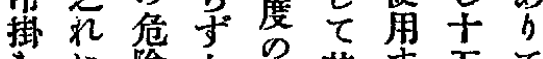

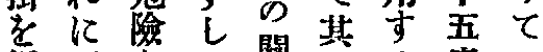

探反然關共る度

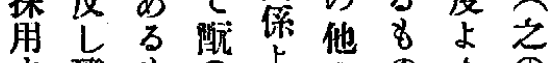

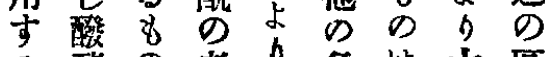

る䤀の老呆各は十區

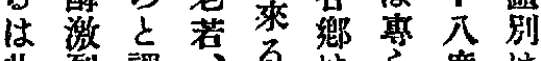

此烈謂名は度は

五 9 《策8 8 冷盗間添

五點來㤩溫の排排の任

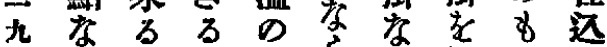

名可關 5 探の温

几故加牦公加用度

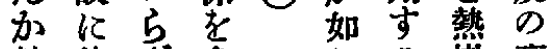

熱徒夺参台掛高

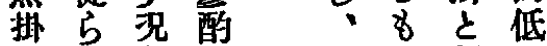

はに食全の稱に

及的与量双

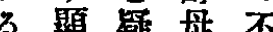

正微任使良

長極査疗の b

ぬ察 b 賞と

ての思

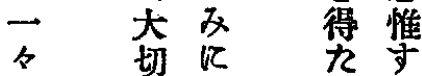

之存上少了

b 5 時

順

記

す

3

は

却

繁

z

8

奛

瞭

$z$

缺

の

恐

n

あ

3

z

ずの 㤌

v -

$\tau \tau$ 個

従腐の

來造 陑

行醅の

は の代

机原恃

? 因

1 性に

あ 有 二

害り

と ぶ 蓜

万齐在

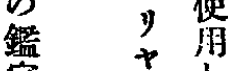

定索索至

即 云 安

古分

酸文に

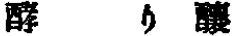

の 8 造 
琵製造表(其)三

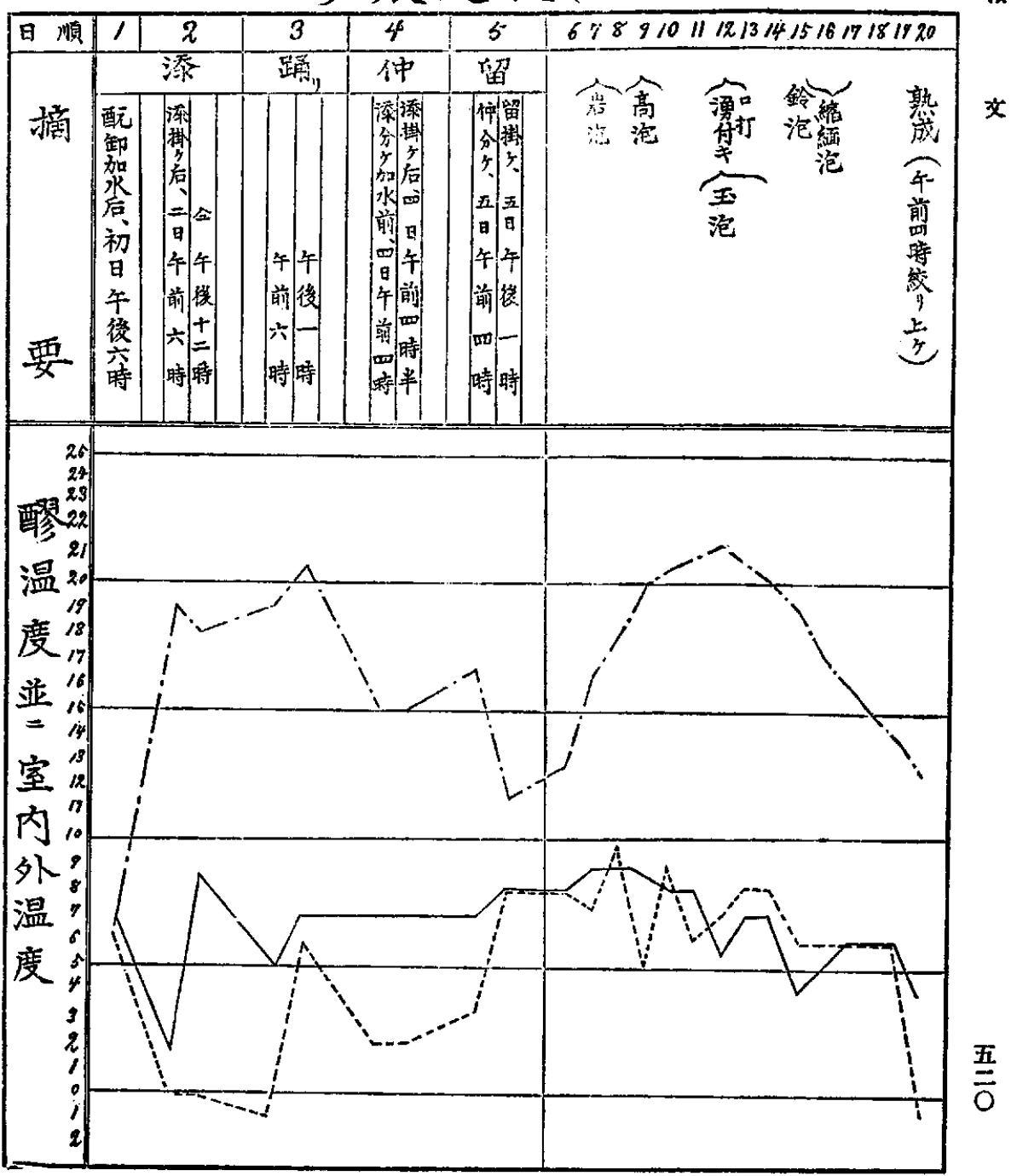




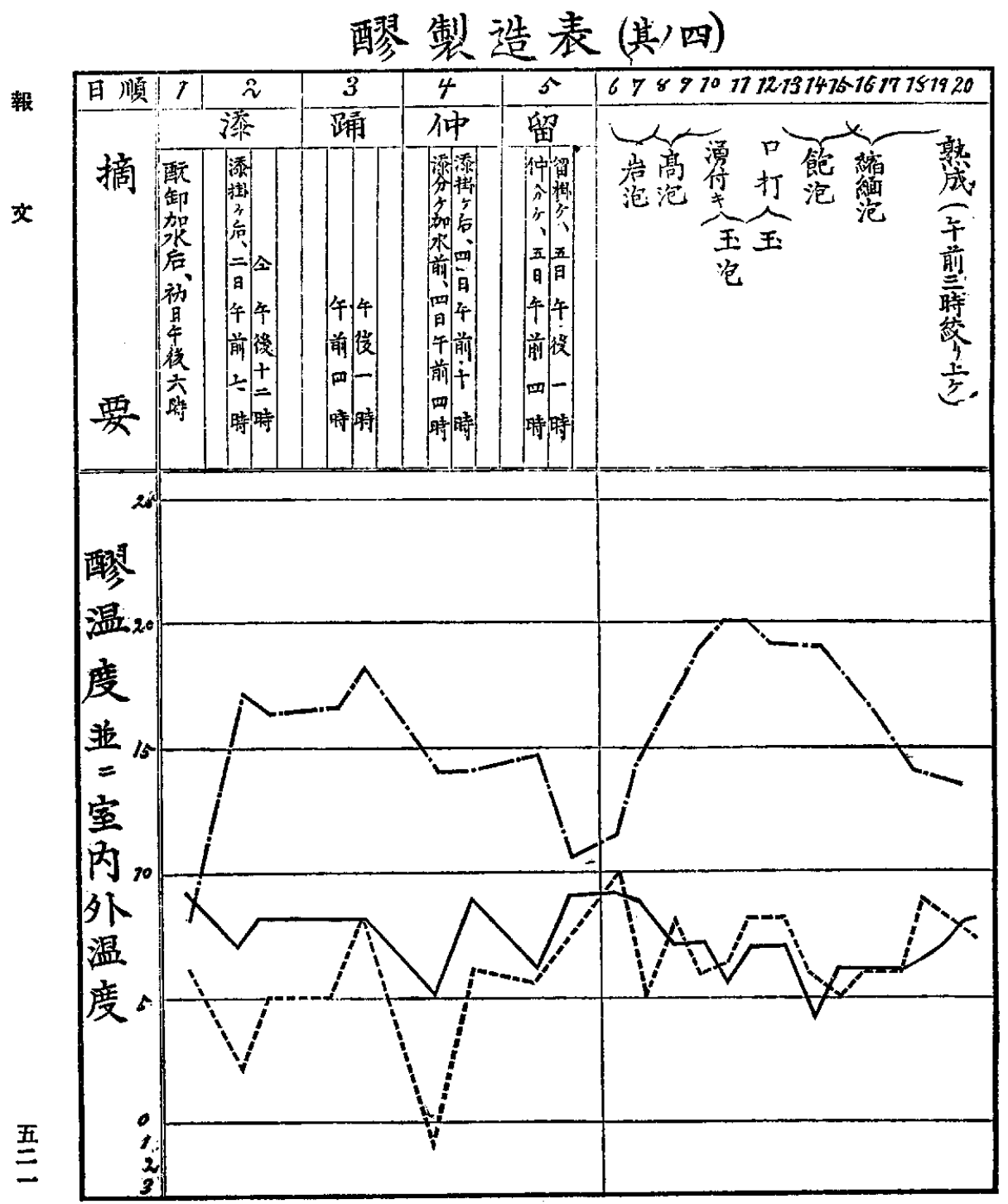




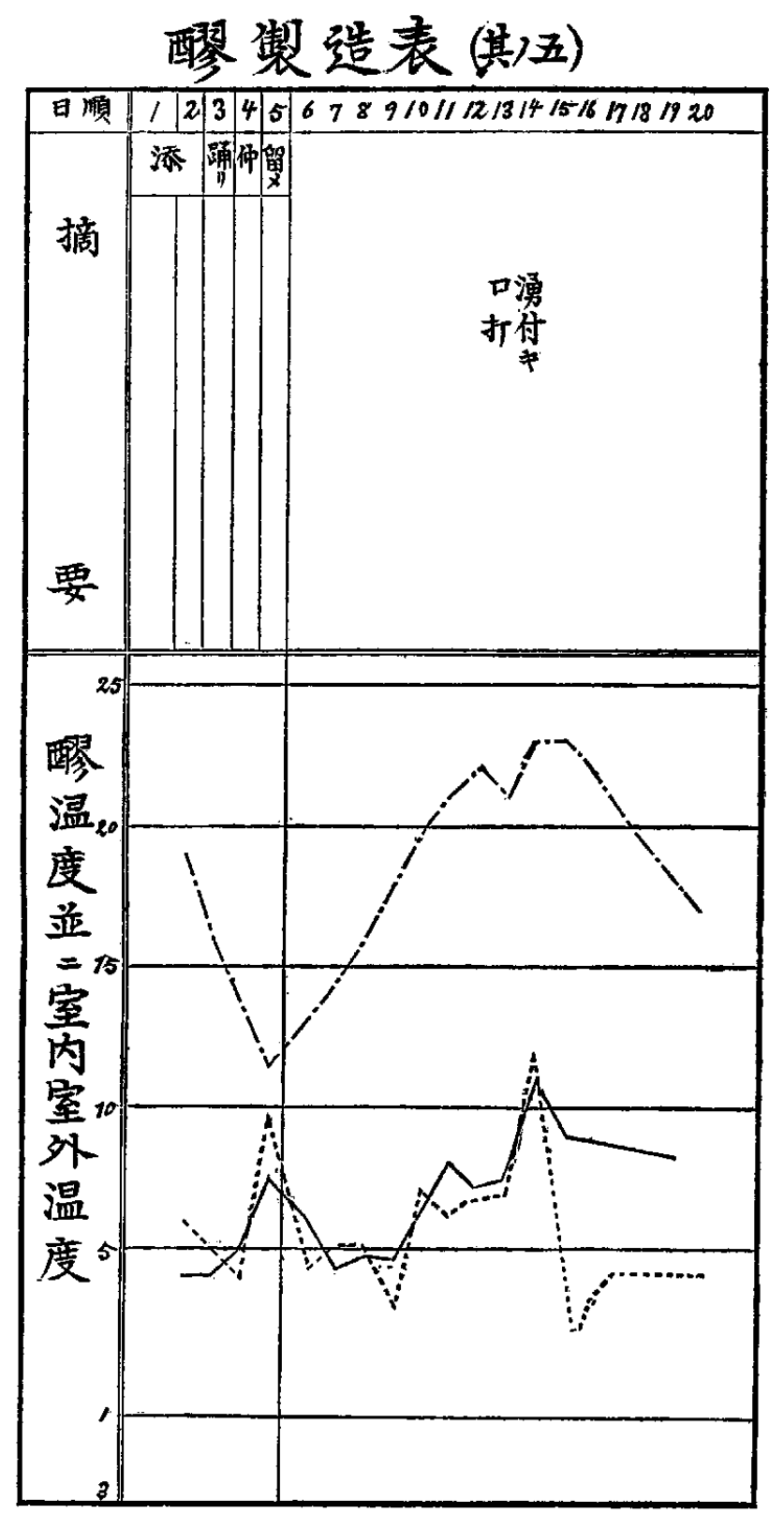


慗製造一覽表（其，六）

\begin{tabular}{|c|c|c|c|c|c|c|c|c|}
\hline 酒各搭裂 & 初添訨込泪度 & 踊 リ & 仲 & 留 & 岩泡 & 口 打 & 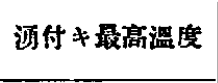 & 熱 成 日 数 \\
\hline $\begin{array}{l}\text { 篓 } \\
\text { 宗 }\end{array}$ & $11^{\circ} . \mathrm{C}$ & $\rightarrow$ & $\begin{array}{l}\text { 少シク前ョ } \\
\text { 垥下ス }\end{array}$ & 少シク低下ス & - & - & $23^{\circ}-24,{ }^{\infty} 2$ & - \\
\hline 醕 & $11^{\circ}$ & - & - & - & 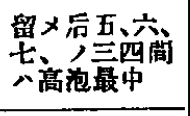 & 留入后九日目 & $24^{\circ}$ & 24 日 \\
\hline $\begin{array}{l}\text { 世 } \\
\text { 界 } \\
\text { 垦 }\end{array}$ & $\left\{\begin{array}{rr}\text { 水添 } & 9^{\circ} \\
\text { 本添 } & 12^{\circ}\end{array}\right.$ & - & - & - & $\sim$ & - & - & - \\
\hline 白 & $14^{\circ}-14^{\circ}, 5$ & - & - & - & 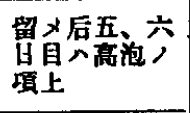 & 留入后入日目 & $27^{\circ}$ & $20-21$ 日 \\
\hline 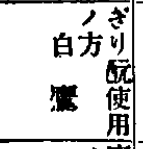 & $\left\{\begin{array}{lr}\text { 水添 } & 7^{\circ}, 3 \\
\text { 本涯 } & 11^{\circ}, 7\end{array}\right.$ & - & - & - & - & - & $23^{\circ}, 9-24^{\circ}, 5$ & - \\
\hline 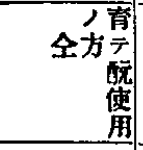 & $18^{\circ}-21^{\circ}$ & - & - & - & - & 一 & $24^{\circ}-27^{\circ}$ & - \\
\hline $\begin{array}{l}\text { 榴 } \\
\text { 点 }\end{array}$ & $\left\{\begin{array}{l}\text { 水添 } 7^{\circ}-10^{\circ} \\
\text { 本添 } 12^{\circ}-12^{\circ}, 7\end{array}\right.$ & - & $10^{\circ}, 5$ & 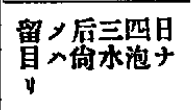 & 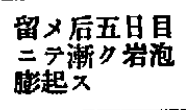 & 留メ后十昌冒 & $24^{\circ}-25^{\circ}$ & 揚分首酸温ハ $22^{\circ}$ 位 \\
\hline 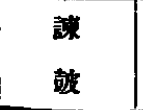 & $10^{\circ}, 5-11^{\circ}$ & - & - & - & - & - & $22^{\circ}$ & - \\
\hline
\end{tabular}


清 酒 (生 酒) 分 析 表

\begin{tabular}{|c|c|c|c|}
\hline 成分酒名 & 向贍 (野田酒) & 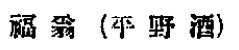 & 糊 波 (大八木酒) \\
\hline アルルール(容量法) & $18,1 \%$ & $18,9 \%$ & $17,6 \%$ \\
\hline 全 固 形 物 & $3,515 \%$ & $3,723 \%$ & $3875 \%$ \\
\hline 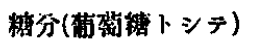 & $0,562 \%$ & $0,737 \%$ & $0,185 \%$ \\
\hline & $0,1773 \%$ & $0,2412 \%$ & $0,3860 \%$ \\
\hline 酸 $\left(\mathrm{H}_{2} \mathrm{SO}_{4}\right.$ トシ & $n, 1962 \%$ & $0,2275 \%$ & $0,2275 \%$ \\
\hline 比 & $0,989 \%$ & $0,990 \%$ & $0,987 \%$ \\
\hline
\end{tabular}

少（6）付 (5) 發 上 な 蒸 (4) 數 (3) 隨 后回 (2) 通

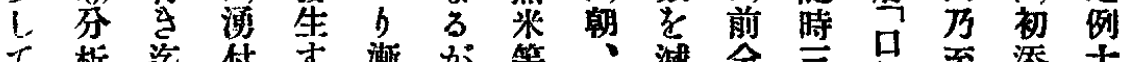

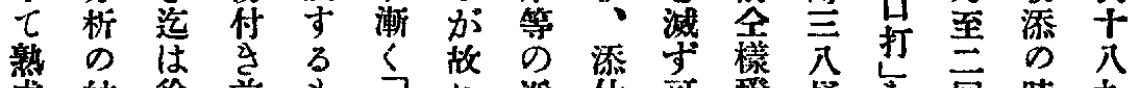

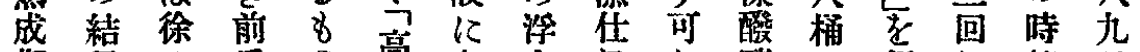

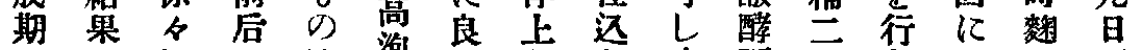
ににに主は氾好艺炎時不本な添の間

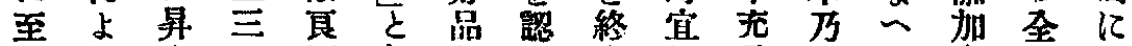

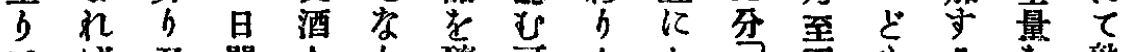

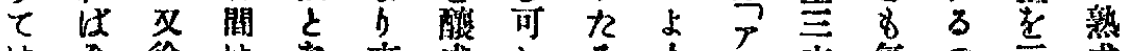

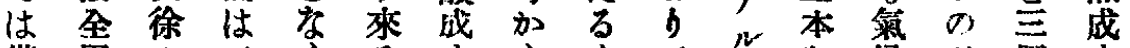

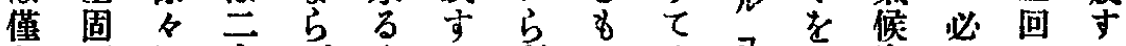

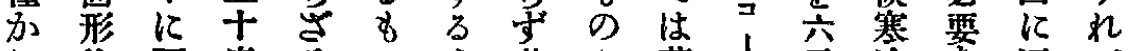

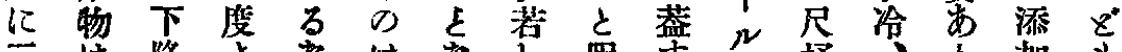

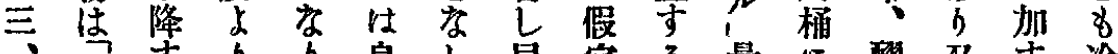

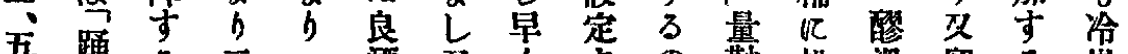

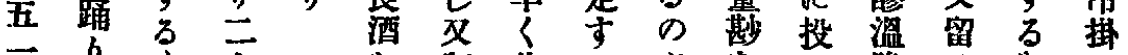

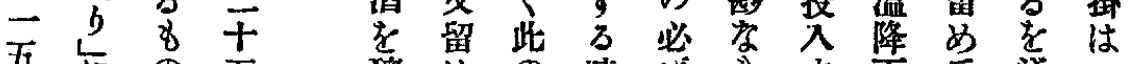

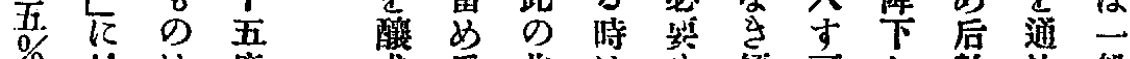
$\%$ 於は成后北は假可し數法般

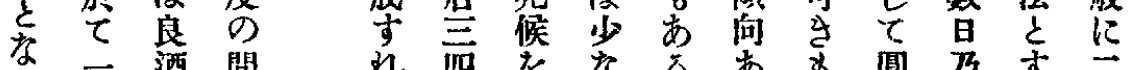

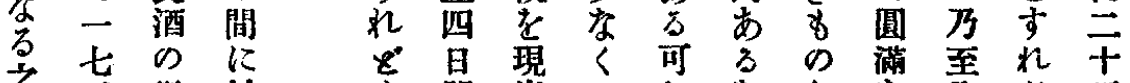

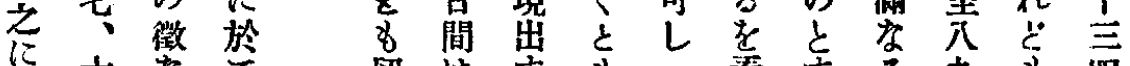

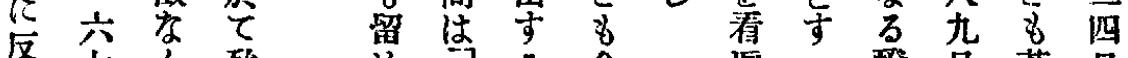

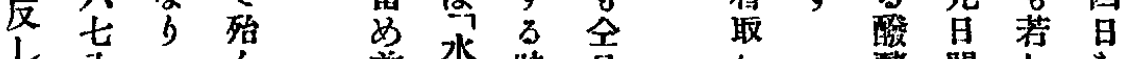
㫕 省永 前水 特 白 后氾 於 及醄四 ๖ せ 溫 $1 \lessdot$ 它 既厄烦 年持四來迄 は漱續高五方は

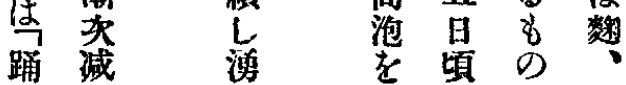
1, 酵間し㐘 方学染要

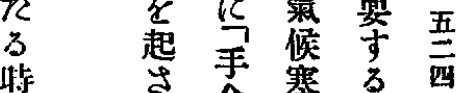
特壳合寒 る

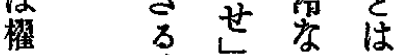
入㙏范方事

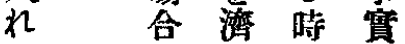
のによは秀 回は 
（1）加 揚 前 ○贠稜名揭 口 13 售槽 飞揚出飞第

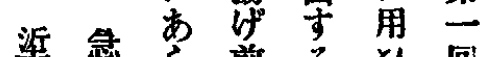

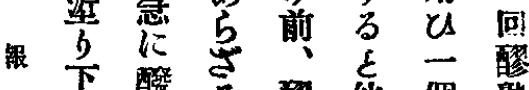

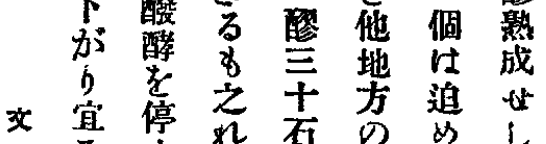
万此石名的亡

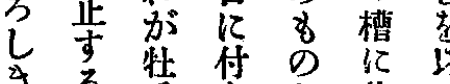
है

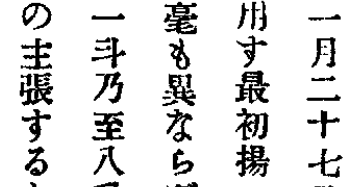

开开至

之方槽午

万蟯要前

酎以几

聞をて一痷

〈の省畫初

儿綉开畧限揚

其解取壳間

可当

利加擭看

點管手

大 $r \quad 5$

略谊设涌

左古办例

D

如 湍

乙 過

守

3

8

の

吾

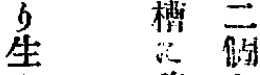

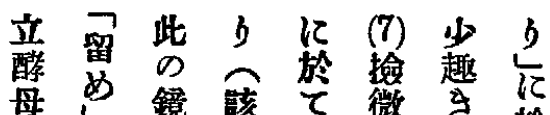

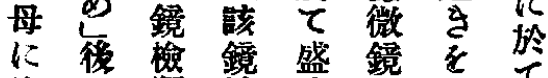

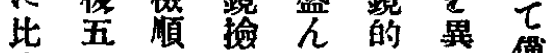

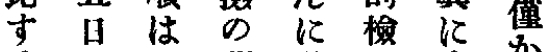

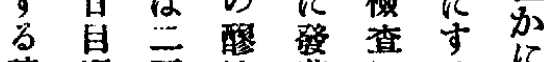

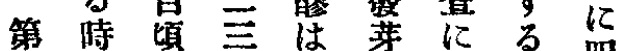
四は古熱繁據年四

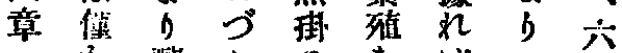
加酸了口政 酒に母後添始 水 揚七のる仕め添 癹紐了这留後

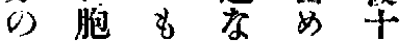
二内のb铉二 石飞し些時

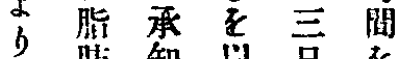
肪盟智旦 分球占 $\tau$ 間 經

一可斯乃過 多しく至 万乃田数机 估至如昆黛 交要間笨 年後添 現文即 0 は名煎 若岩 承 ᄂ 泡飞 点盗中瞙 口排尘 打比势梁 後强莱 吐醀盛 の

發醋等徵 莪露亏候 酰慢發市 甘察芽当 著方繁 क ᄂ क 殖の D存了 減營报

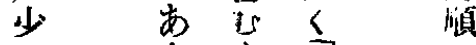
t. 孤 $\%$

示

め せ $\sum_{3}$ 潮 次 增 加 ¿ 逐 k $-$ 八

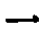
$\%$ 容 量 港 要 客 3 z 虾 ' 醉 沼 て は娄 㕝移頮

直的

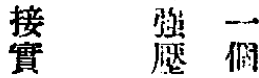
撿艺は 


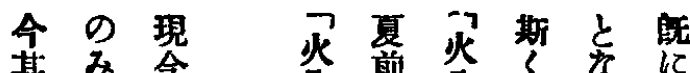

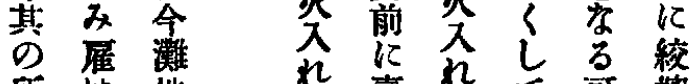
所地 要 れ方 人常に 數 $\kappa \tau$ 並は使 に豊役第占它它此九 本業措 年佉る

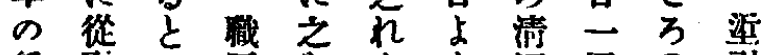
賃整之工学山酒回の引

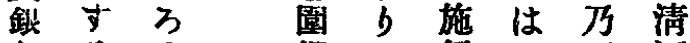
をるの 指 8 職 げの $工$ んたは にる 率 类 II 丹

$\tau$ 波 勞 人 鋠 D 如 $\tau$

等

此 $儿$

較 全

的 國

低 多

廉岐

䒚 郡

b)

最

守

呇

の

職

I

毎

年

酒

造

時

期
桶卞行芝至酒

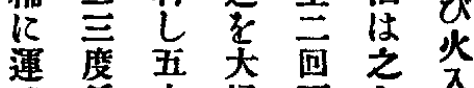
县了七に喬細藏 登名度 入文物 万占和报

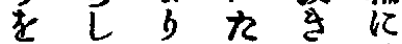
密六了移 飞る十桶

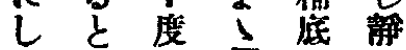
$\tau$ の 賖間炎沈せ

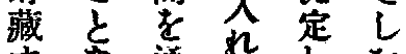

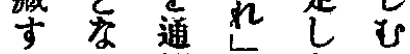
万例迄尔 它放了時 の し置とは と槅守之五 園笛旦 交只

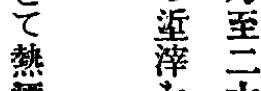

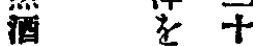

除

直 去間

古类

に 万經

箱過

詰

め

K

L

盛

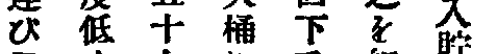

嵌
火
管
藏

挆る (2)

用老 灘

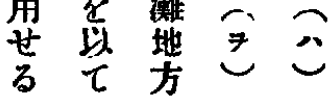

近炡酒

受哉在持の制 第妾或在 苯品

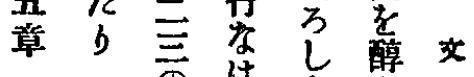
六は良

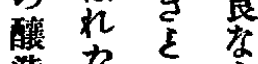

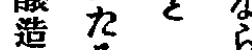

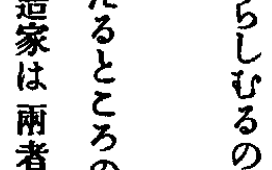

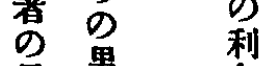
長男睢 椟箖 提 器 万螺

稉

嫄

㩁

析 器 裹

的需

厴

推 行

器な

根槙 は

I椾 $x$

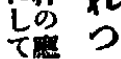

的柴

等索

俈品

菜筩何

吾 


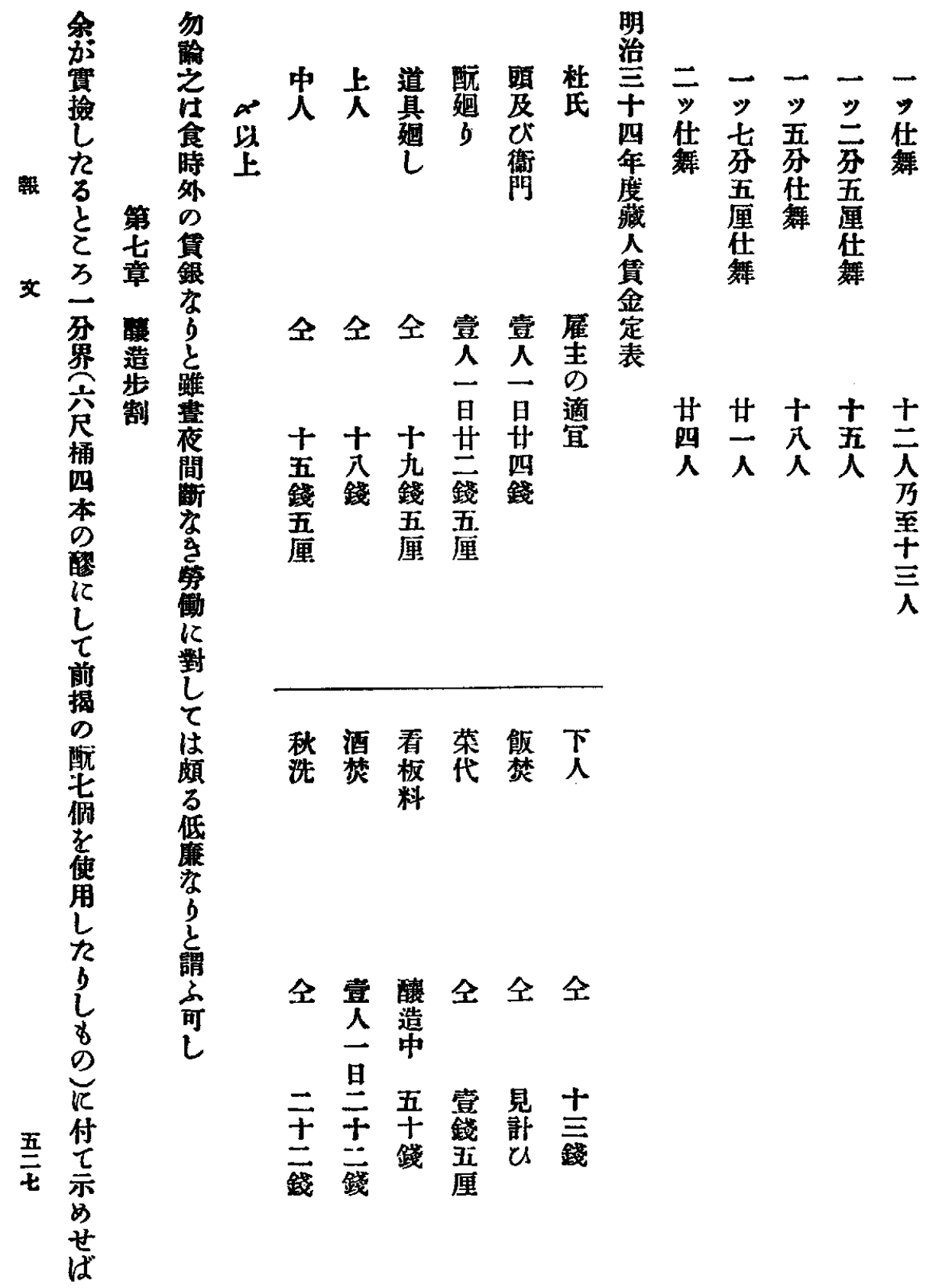




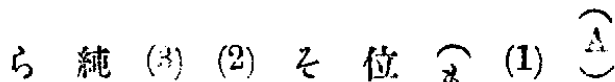

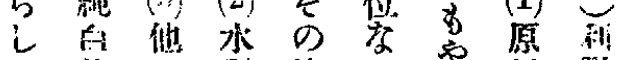

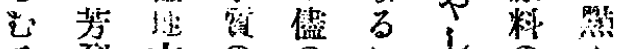

る 烈方の片它

ののに佳 \& \& の 精

利若 此豆 $D$ 不如㨨

市桨乲拘

b无方化

के 米

周 猌

守 在

万础i

M

ii

?

$\tau \varepsilon_{0}$

滥

灌

$D$

品

留

离

E.

好

先
弓让莎

2 上家に

ま市梦推

\& है

の $k$ V

t. $\tau$ 度

稳恃々

㧮特

于色 意

万留市

如 る

L. 晋 D

工湔 及

x $\cdots$ 文

は袋占饿

蓋 钱
落

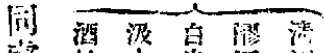

庭

管

5

的沓类不

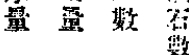

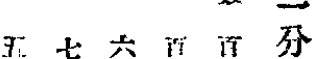

浩百十千拎矿算派

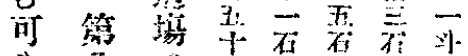

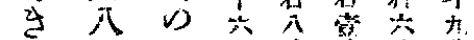

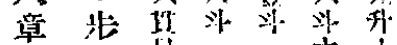

㰾

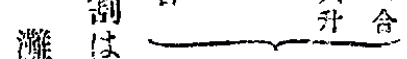

女

要

法 表

() i)

特 如

色
白白为粠跈

苔 米 菲 留

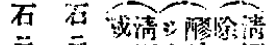

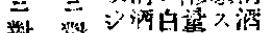

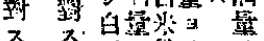

人

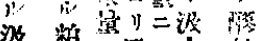

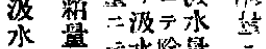

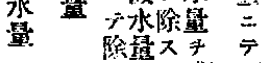
ス $=$ 浅

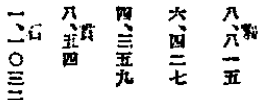

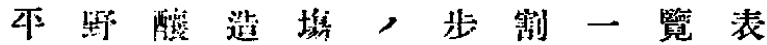

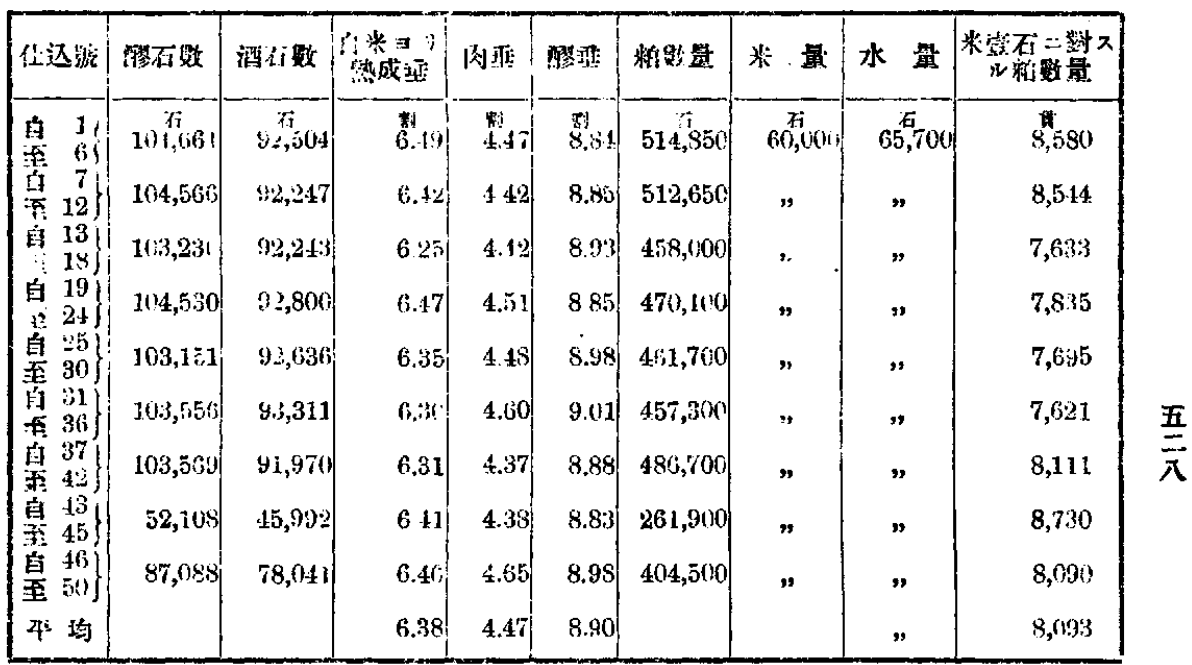




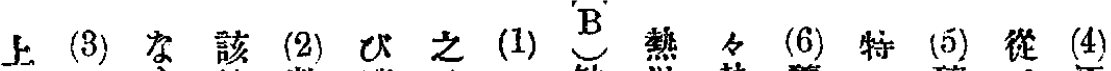

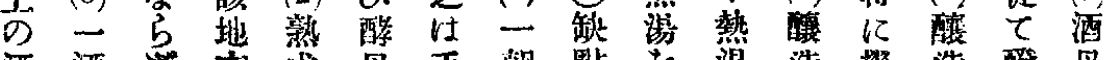

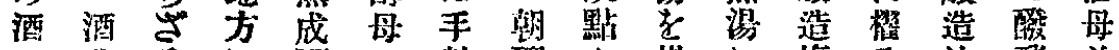
造 造 る

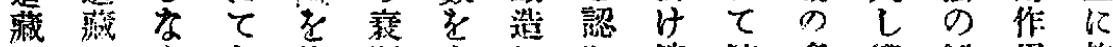

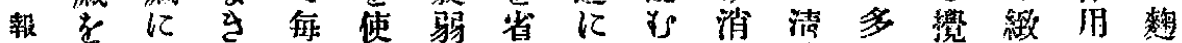

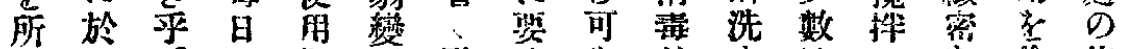

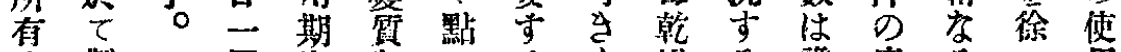

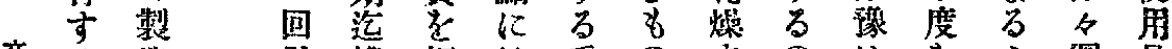

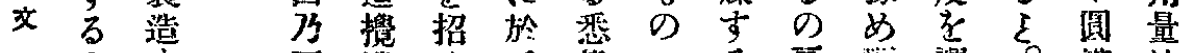

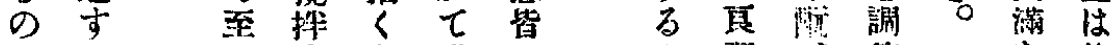

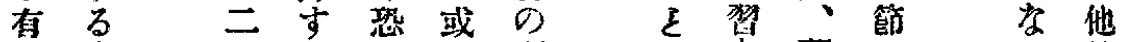

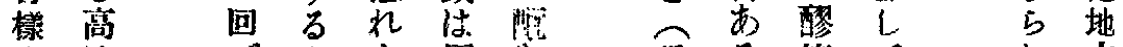

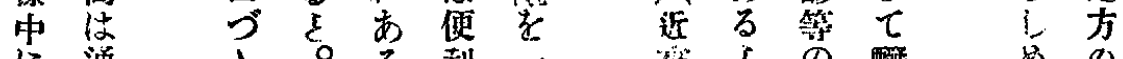
に通 は 例

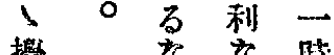
稀 五 に百常

藏石 數 よ 해

干王

乌石

以. 丙

上外

を

超 間

㴗

当亦

के 3

○)

市

. $r$

然间

万地

江方

此保

管 $\tau$

$+1$

事渵

中遄 の

芜分平

九

梳得

藏 $\tau$

D

位

置

䠹宗尔時

㨋

の

例

等

8

在

格

别

要

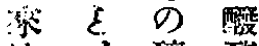

\&)

生: 酸酸

夫 割

移特室作

江江定用

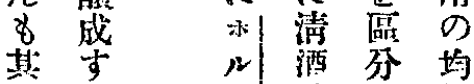

的。

大

部 惯

は 冽

數 $九$

+ 当

晨袥

is

使

in

于

3

r.

c

客

3

s.

み.

凉

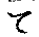

微

生

物

D

侵

余

睆 ᄂ 等

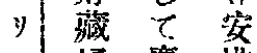

一桶磨排

D记壦

如 粼 得

寻微

消飞坐

霖生物的

劑十の

先数德

健目

用間艺

要及防

万至 纴

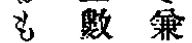

の十社

あ日

る間

当大用

氣

中 器

《 具

晒

与 對

ᄂ $\frac{L}{r}$

星嵒
の 合

唒京

热

纯 8

立

浄出

क $ह$

る

種

$の$

變

tr

减

退

于

亲

效

萧

b. 


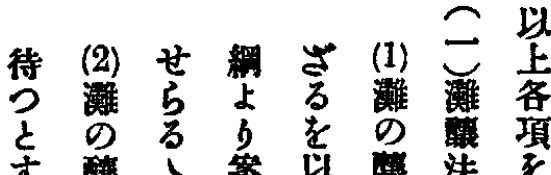

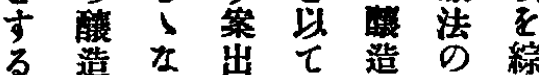

\&法 3 前法批合

乾法然揭艻利

燥 概 れ第る

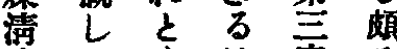

冾と和は章当

な順米なよ椱

3 境質了引鹤

氣に搗鹳第 の

候 白口四觀

るの䀧章古

風名度造 即る

士の法ち字

のと惊原素

之解割之料之

に釋以索的

調世走化精 酒

和さ學 鹳 の

方方上割秘

万可る上合 訣

亿名加 方 的

あ ら 如見よ 釀

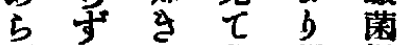

于゙假应非微

ん令必難 醉

牧原占等造物

何料守可 の

んのしさ旗

そ 精 क 點 段 分

能袋 共 甚法 及

く宜の添

今方要尠添溷

日儿学仲度

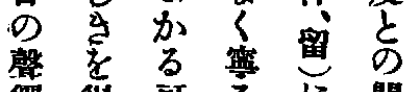

賈街可亏に

堡老し利到係

保老點学調

梦多悉和

得方文了《

等杜此外

世在詺の索

人 識大
の序

觀穴は之(4) 互

あに最在製事に

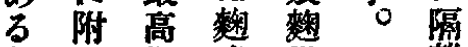

能溫米温 離

以吉度精度

可它白

虞 派

第早告四元

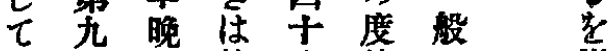

蹄章酒数度他に 以

結藏室范地高艺

寸結 の市方手杜

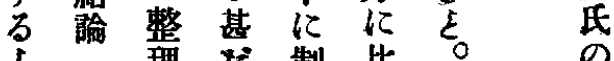

上理 无制比。 の

右充不限し策

の 想完し正 任

如待全た 著

つ k य $L$ 消

ᄂ

改 $\tau$ b 相

造且違

耗

賈

D

共

角

可 瞕当

高街责

の生证

業

独

$\varnothing$

統

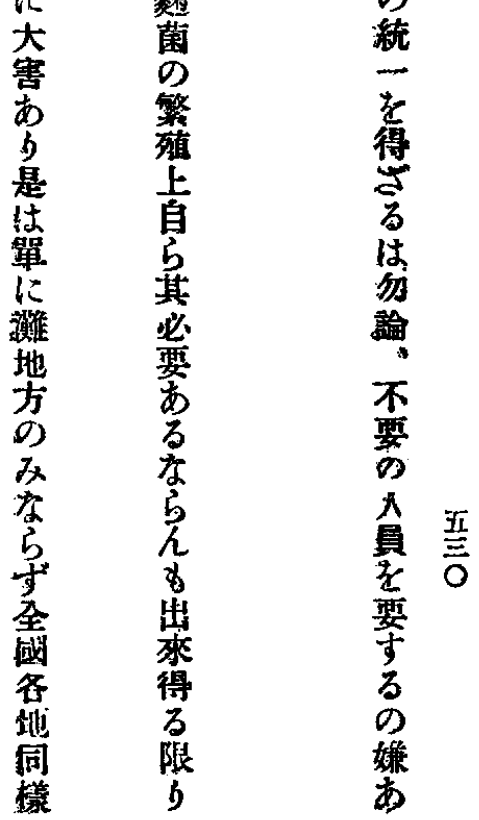




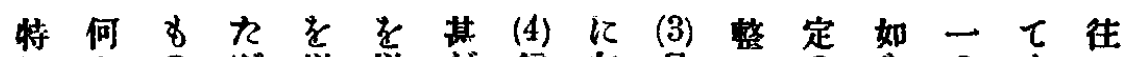

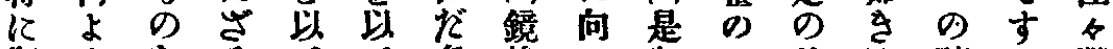

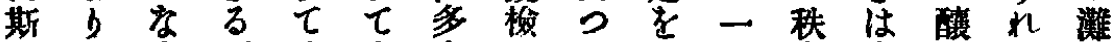

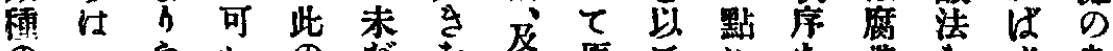

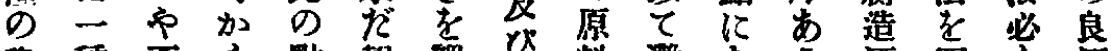

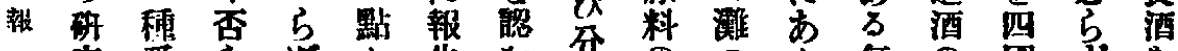

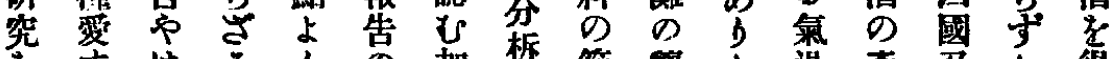

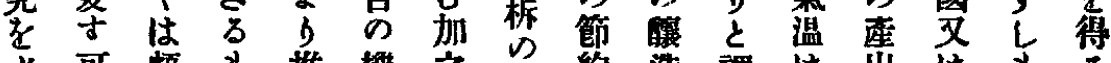

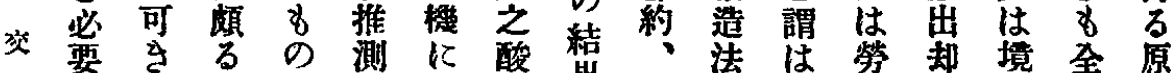

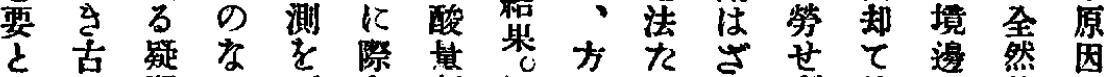
考有問る下會割に法るる导他に然老

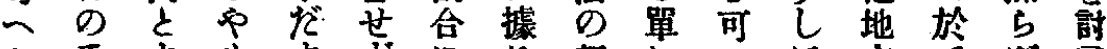

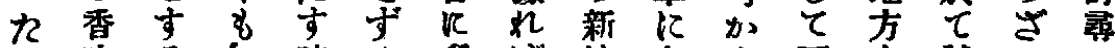
る味る 知時を多ば按在ら良よ試るし

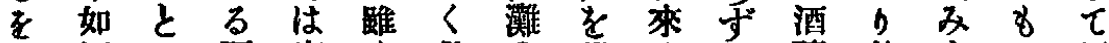

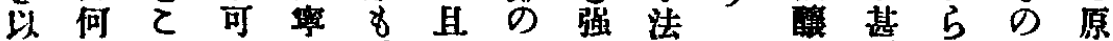

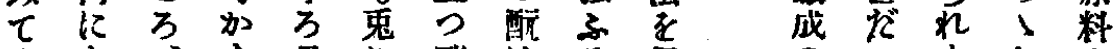

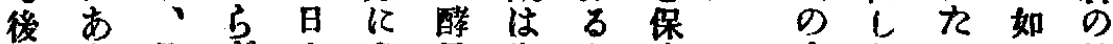
段 具守本角母概占守 主加る

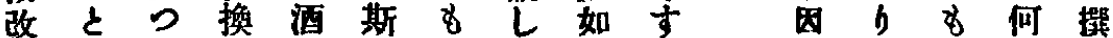

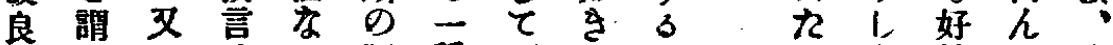

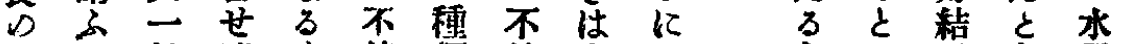

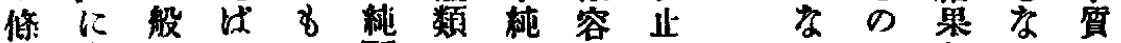
項 8 に に不旦本は学限酵にb 於拘本酒幾使 b行絕 朱酒は種用居口なえ

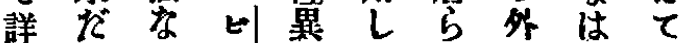

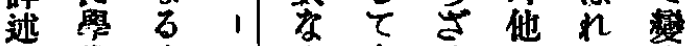

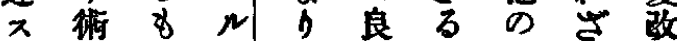

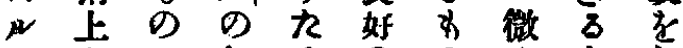

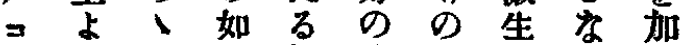

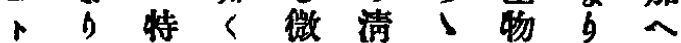

何色單生酒如等 ᄂ

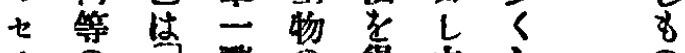

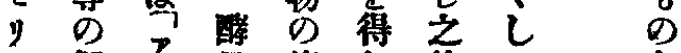

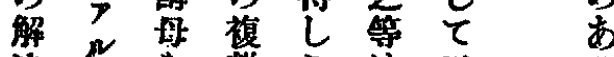

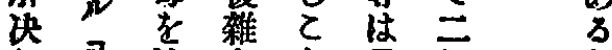

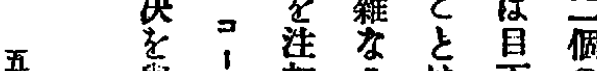

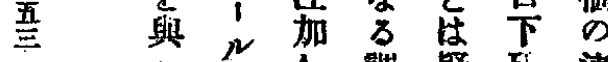

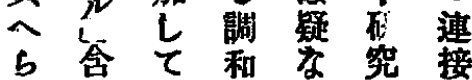

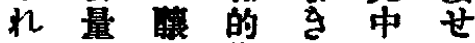

要成作事江方

万多䨘偈短

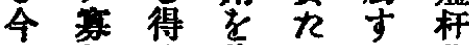

竞

方皇奏代美

几深世近

乎徽 严醇

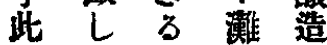

の て の

點 क力 间

小明禁一巧

b 加 万象

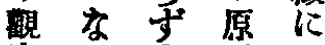

察 9 全料䟥

日如方待方名

䒽

驾

壵

管

可買司守

红灘同我

特彼吕市

地地地名

酒整等算告

口濕占间見

秘型て一方

訣冾す它

生而占杜

瞚温加昨、氐

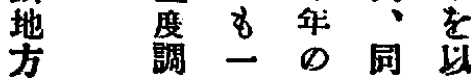




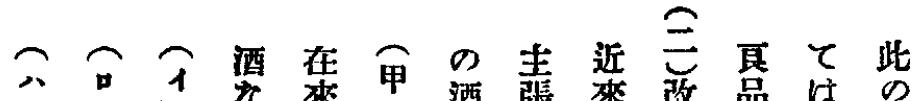

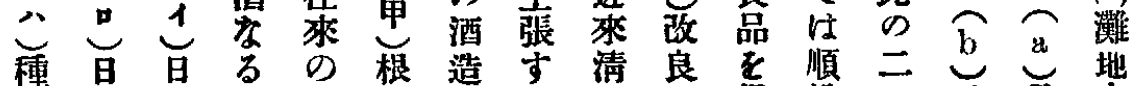

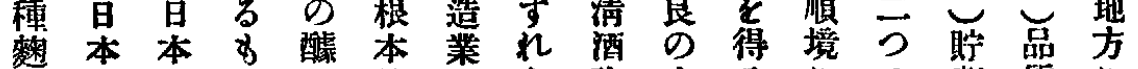

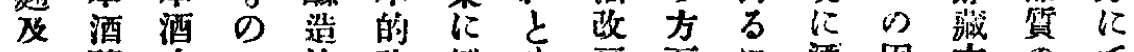

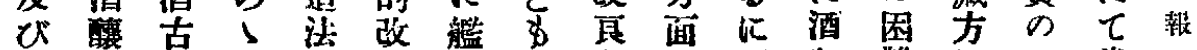

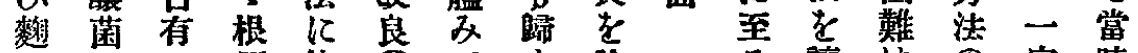

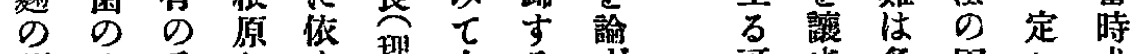

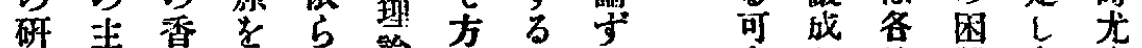

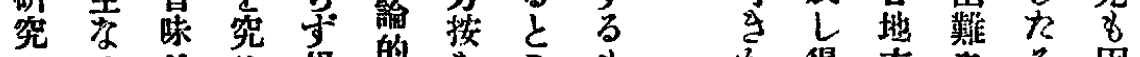

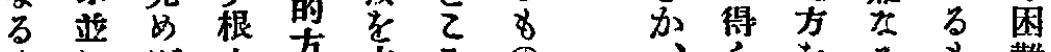

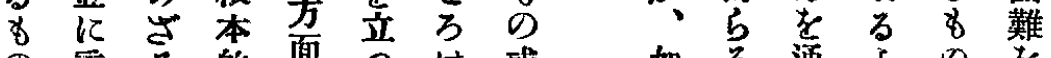

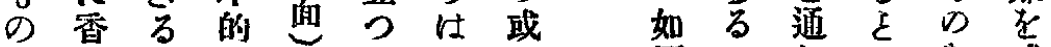
に味可改る經、何る仕を感

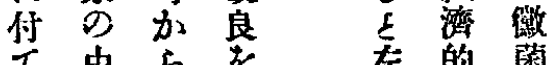
七 由 5 在的茐 す施宁學 来 即 $匚$ 如多 上 た ち ᄂ L 量京 る 日 紮本

原 酒 D 3

矿 䏇 究 成<smiles>[Z17]#CCCCCC</smiles>

h

と紧

世

ば

第

着

k

化

点

び

徵

棌

學

上

b

日

艮 或

酒卧

老獄

得 生

$\alpha$ 學

喜步

万 b

名

沶賞

5 策

落

3

需

浽

$\tau \perp$

齐

渄 珤

融

法

行其

考

几 䌘

各 求

地

次枚 $\tau$

廿今口

壮白話

品の夌

質處证

表如

偒 何 特

I $k$ k

る世鹳

ほばの

告 如如

ᄂ 信絫

七る 産

安 地

全视

六云於

館はて

藏 几 -

ᄂ上層

得 b 基

万ह 8

加㛎 然

の何了

二 $k$

點 诰認

に注む

外品 即

禁筧該

于定地

の 方

優 $k$
街じ

難 居

居尚

は

次

D

愐

b 


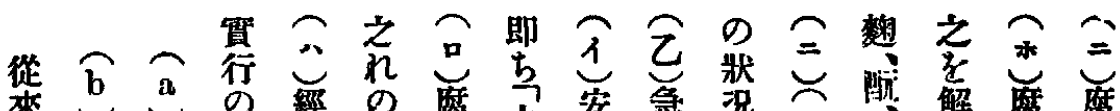
來

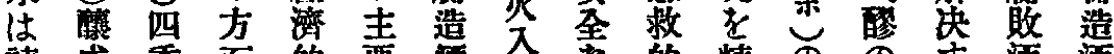
報請成季面的要梄艺な的精のののす酒酒

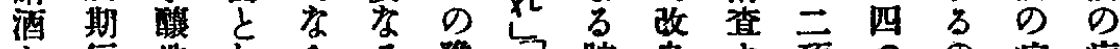

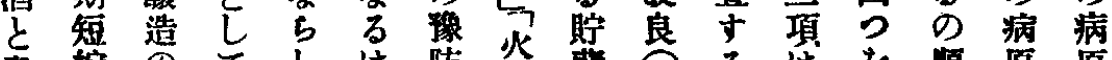

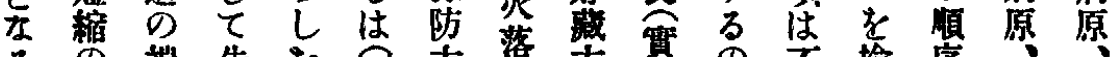

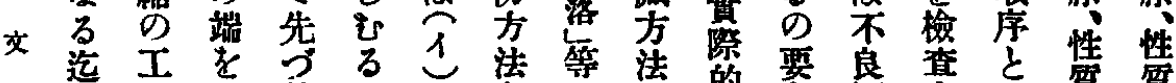

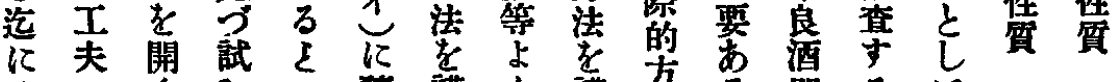

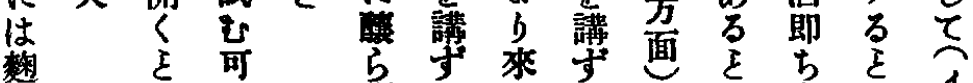

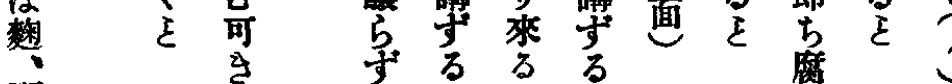

酳应

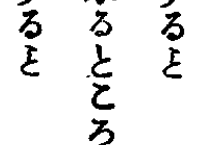

榢

の

椇

種

s

宜

造

酒

腐

賋

酒

k

万

操

付

$\tau$

손

z

可

造

क

K

取

$\frac{b}{c}$

焦

眉

$\tau$

の

急

吾は

$b$

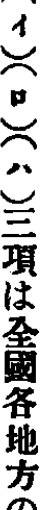

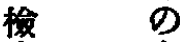

查良

t好

施酒

主付

は $\tau$

多

喻

糜

敢

酒

k $k$

あ 至

b

は 汽

火 の

落科

虫

前 


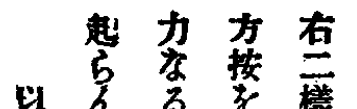

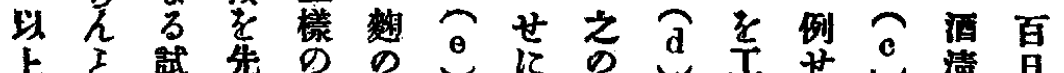

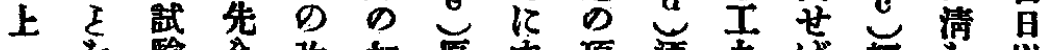

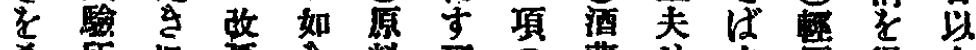

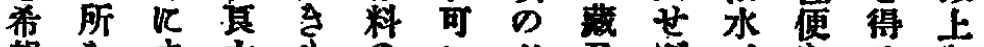

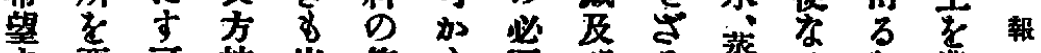

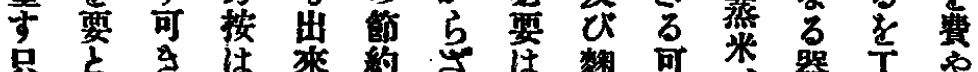

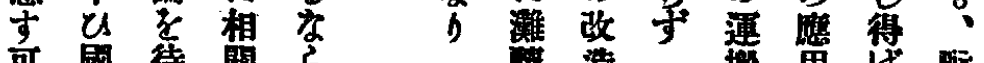

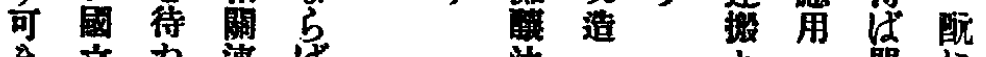

己立㤂連

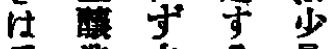

后造之量

者試老方に

驗遂故て

專所 行

らの专常

地方

方はの同た

の 慨 手 時 点

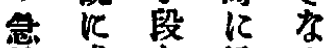

救成上遂

法

中

k

跑

的立 L 行

政

L

良緒沬可

老に中

眼 就 央

目等部の

之水な

L $3-n$

七個

立品 0

号國自

可地立甬

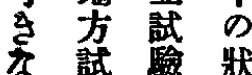

b 驗 䌘

埴各省

势方 势

做 に急

之 数 救

㤎

如

特

亿

類

室

の

如

き

は

㵝

I

告

$\tau+$ 的

剩 の 改

个有良

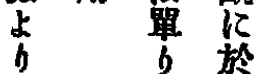

洗 時

米旦

牛

䇝上切

に操

於 作

蛪正

操看

作 寸に

の 万於

如 の

可了

人 添

力

に

点仲

侥勞留

尌务留

ᄂ 點 如

$\tau$ k 2

保

謢

上

要

考

$\tau$

8

便

\%

万

器

根

鹿

筩

尔

早

8

る

の

於筑

$\tau$ 雜

著な

ᄂ

繁

效 吾

万節

九 減

ᄂ

忽

多

方

好 